\title{
GENETIC ALTERATIONS IN PHEOCHROMOCYTOMA AND PARAGANGLIOMA
}

Jenny Welander

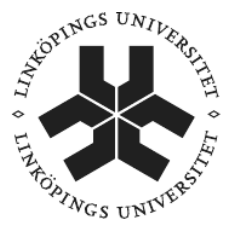

\section{Linköping University}

\author{
Division of Cell Biology \\ Department of Clinical and Experimental Medicine \\ Faculty of Health Sciences, Linköping University \\ SE-581 85 Linköping, Sweden
}

Linköping 2015 


\author{
Main supervisor: \\ Professor Peter Söderkvist \\ Linköping University \\ Co-supervisor: \\ Professor Oliver Gimm \\ Linköping University
}

(C) Jenny Welander, 2015

ISBN: 978-91-7519-145-4

ISSN: 0345-0082

Previously published papers included in this thesis have been reprinted with permission of the respective copyright holders:

Paper I: (C) Oxford University Press

Paper II: (C) Bioscientifica

Paper III: (C) Endocrine Society

Printed by LiU-tryck, Linköping, Sweden, 2015. 
If you want to go fast, go alone.

If you want to go far, go together.

- African proverb

To my family 



\section{ABSTRACT}

Pheochromocytomas and paragangliomas are neuroendocrine tumors that arise from neural crest-derived cells of the adrenal medulla and the extra-adrenal paraganglia. They cause hypertension due to an abnormally high production of catecholamines (mainly adrenaline and noradrenaline), with symptoms including recurrent episodes of headache, palpitations and sweating, and an increased risk of cardiovascular disease. Malignancy in the form of distant metastases occurs in $10-15 \%$ of the patients. The malignant cases are difficult to predict and cure, and have a poor prognosis. About a third of pheochromocytomas and paragangliomas are caused by hereditary mutations in a growing list of known susceptibility genes. However, the cause of the remaining, sporadic, tumors is still largely unknown. The aim of this thesis project has been to further characterize the genetic background of pheochromocytomas and paragangliomas, with a focus on the sporadic tumors.

First, we investigated the role of the genes known from the familial tumors in the sporadic form of the disease. By studying mutations, copy number variations, DNA methylation and gene expression, we found that many of the known susceptibility genes harbor somatic alterations in sporadic pheochromocytomas. Particularly, we found that the NF1 gene, which plays an important role in suppressing cell growth and proliferation by regulating the RASMAPK pathway, was inactivated by mutations in more than $20 \%$ of the cases. The mutations occurred together with deletions of the normal allele and were associated with a reduced NF1 gene expression and a specific hormone profile. We also detected activating mutations in the gene EPAS1, which encodes HIF-2 $\alpha$, in a subset of sporadic cases. Microarray analysis of gene expression showed that several genes involved in angiogenesis and cell metabolism were upregulated in EPAS1-mutated tumors, which is in agreement with the role of HIF-2 $\alpha$ in the cellular response to hypoxia. In order to comprehensively investigate all the known susceptibility genes in a larger patient cohort, we designed a targeted next-generation sequencing approach and could conclude that it was fast and cost-efficient for genetic testing of pheochromocytomas and paragangliomas. The results showed that about $40 \%$ of the sporadic cases had mutations in the tested genes. The majority of the mutations were somatic, but some apparently sporadic cases in fact carried germline mutations. Such knowledge of the genetic background can be of importance to facilitate early detection and correct treatment of pheochromocytomas, paragangliomas and potential co-occurring cancers, and also to identify relatives that might be at risk. By sequencing all the coding regions of the genome, the exome, we then identified recurrent activating mutations in a novel gene, in which mutations have previously only been reported in subgroups of brain tumors. The identified mutations are proposed to cause constitutive activation of the encoded receptor tyrosine kinase, resulting in the activation of downstream kinase signaling pathways that promote cell growth and proliferation.

In summary, the studies increase our biological understanding of pheochromocytoma and paraganglioma, and possibly also co-occurring cancers in which the same genes and pathways are involved. Together with the findings of other scientific studies, our results may contribute to the development of future treatment options. 



\section{POPULÄRVETENSKAPLIG SAMMANFATTNING}

Feokromocytom och paragangliom är tumörer i binjuren respektive paraganglierna som ofta producerar stora mängder av stressrelaterade hormoner, t.ex. adrenalin. De orsakar därför högt blodtryck, med relaterade symtom som hjärtklappning, svettningar, huvudvärk samt en ökad risk för potentiellt dödlig hjärt- och kärlsjukdom. Många av tumörerna är godartade i meningen att de inte ger upphov till spridd cancer, men drygt en tiondel av fallen är elakartade och har en dålig prognos, med ca 50 \% femårsöverlevnad. Idag finns det inga säkra sätt att förutsäga om en tumör är elakartad och inte heller någon effektiv behandling för tumörer som spridit sig. Det saknas även kunskaper om de biologiska mekanismer som styr tumörernas uppkomst. Omkring en tredjedel av tumörerna är kopplade till ärftliga tumörsyndrom som orsakas av medfödda mutationer i specifika kända gener. De resterande fallen utgörs av sporadiska tumörer, och vad som orsakar dessa vet man mycket lite om. Syftet med detta avhandlingsprojekt har varit att kartlägga den genetiska bakgrunden till feokromocytom och paragangliom, med fokus på sporadiska tumörer.

Projektet började med att vi undersökte de gener som är kända från ärftliga feokromocytom och paragangliom i den sporadiska formen av sjukdomen. Resultaten visade att flera av dessa gener också är förändrade i de sporadiska tumörerna. Förändringarna var förvärvade, d.v.s. de förekom i tumörernas DNA men inte i patienternas normala DNA. Vårt viktigaste fynd var att genen $N F 1$, som tidigare inte misstänkts i de sporadiska tumörerna, var muterad i mer än 20 \% av fallen. Genen har en viktig reglerande roll när det gäller att hindra celler från att dela sig, men denna funktion förstörs då genen muteras. Vi hittade även genetiska förändringar i en annan gen, som har en viktig roll i cellernas svar på syrebrist. Det visade sig att tumörer med dessa mutationer molekylärbiologiskt tillhör en annan grupp än de med NF1-mutationer, vilket kanske kan komma att ha betydelse för behandlingen av patienterna. I nästa steg satte vi upp en ny typ av DNA-sekvenseringsteknik för att undersöka ett stort antal tumörer. Vi fann att cirka hälften av tumörerna har mutationer i någon av de kända generna, samt att den nya tekniken kan vara lovande för snabb och kostnadseffektiv klinisk genetisk testning. Några av fallen som verkar vara sporadiska visade sig i själva verket ha ärftliga mutationer. Att hitta sådana fall kan vara av stor vikt, dels för att kunna ge rätt behandling och upptäcka tumörer tidigt, och dels för att kunna identifiera släktingar som riskerar att drabbas. I den sista delen av projektet var målet att söka efter nya gener som är inblandade i de tumörer som man hittills inte vet någonting om. Vi använde en ny teknik för att undersöka de kodande delarna av alla mänskliga gener och hittade då förändringar i en för sjukdomen helt ny gen, i vilken mutationer tidigare bara setts i ett fåtal hjärntumörer. Tillsammans har resultaten från dessa studier gett oss en ökad förståelse för hur feokromocytom och paragangliom uppstår, och förhoppningsvis kan detta bidra till utvecklingen av framtida behandlingsmetoder. 



\section{TABLE OF CONTENTS}

1. LIST OF PAPERS

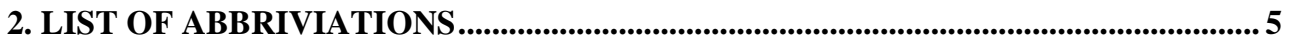

3. BACKGROUND........................................................................................................................... 7

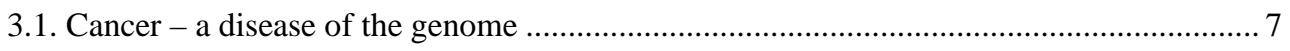

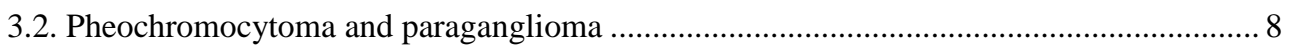

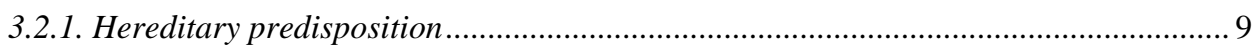

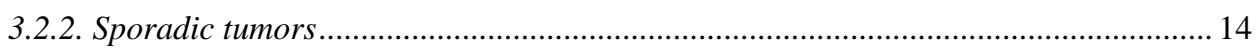

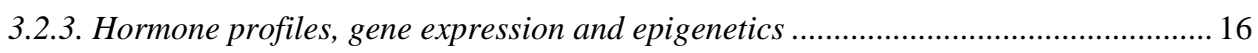

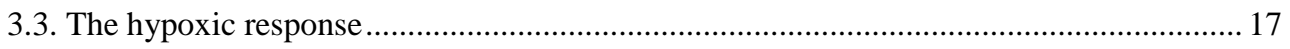

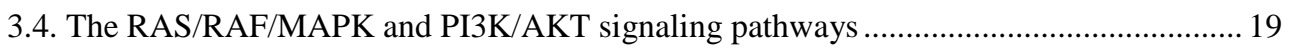

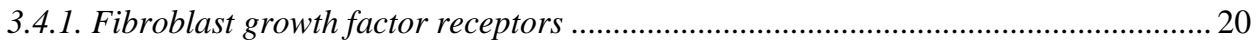

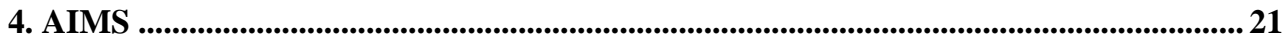

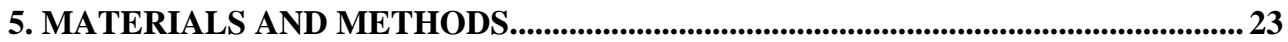

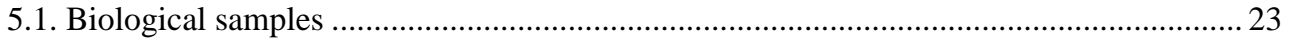

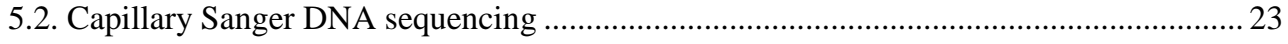

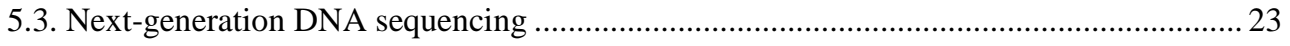

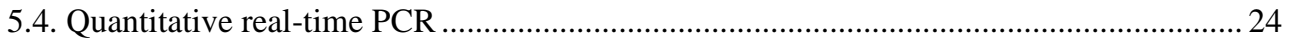

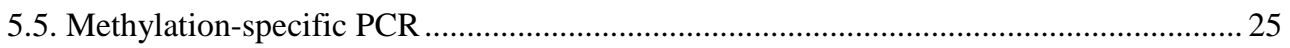

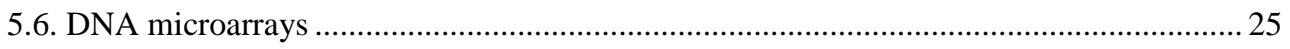

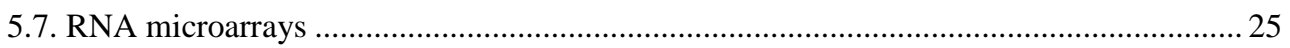

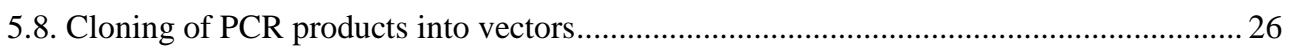

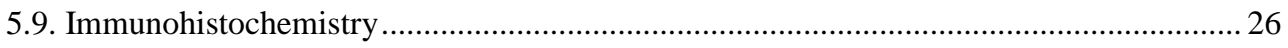

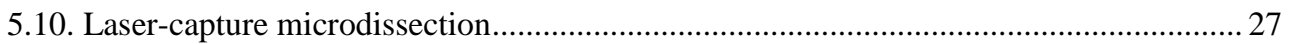

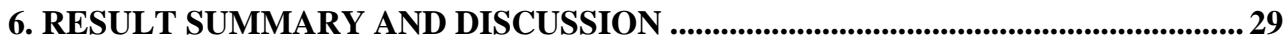

6.1. Integrative genomics reveals frequent somatic NF1 mutations in sporadic

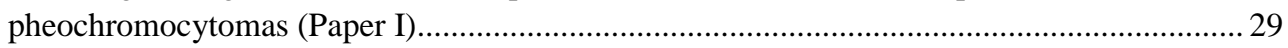

6.2. Frequent EPAS1/HIF2 $\alpha$ exons 9 and 12 mutations in non-familial pheochromocytoma

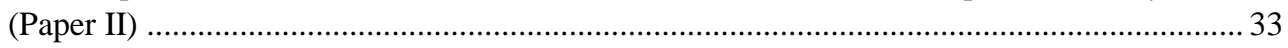

6.3. Rare germline mutations identified by targeted next-generation sequencing of susceptibility genes in pheochromocytoma and paraganglioma (Paper III) ........................... 35

6.4. Activating FGFR1 mutations in sporadic pheochromocytoma (Paper IV)....................... 39

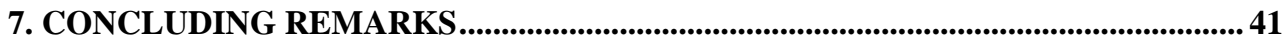

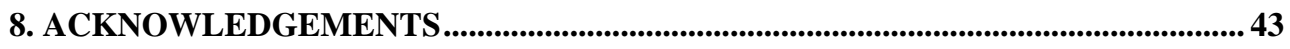

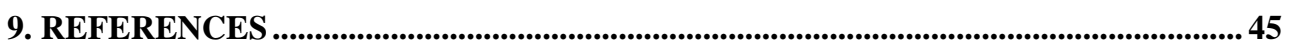

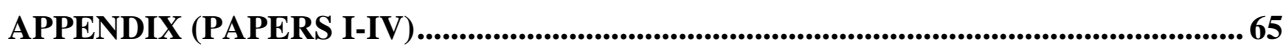




\section{LIST OF PAPERS}

This thesis is based on the following original papers, which are referred to in the text by their Roman numerals:

I. Welander J, Larsson C, Bäckdahl M, Hareni N, Sivler T, Brauckhoff M, Söderkvist P and Gimm O (2012). Integrative genomics reveals frequent somatic NF1 mutations in sporadic pheochromocytomas. Human Molecular Genetics, 21: 5406-5416.

II. Welander J, Andreasson A, Brauckhoff M, Bäckdahl M, Larsson C, Gimm O and Söderkvist P (2014). Frequent EPAS1/HIF2 $\alpha$ exons 9 and 12 mutations in non-familial pheochromocytoma. Endocrine-Related Cancer, 21: 495-504.

III. Welander J*, Andreasson A*, Juhlin CC, Wiseman RW, Bäckdahl M, Höög A, Larsson C, Gimm O and Söderkvist P (2014). Rare germline mutations identified by targeted next-generation sequencing of susceptibility genes in pheochromocytoma and paraganglioma. Journal of Clinical Endocrinology and Metabolism, 99: E1352-1360. *Shared first authorship

IV. Welander J, Gustavsson I, Ekman C, Brauckhoff M, Brunaud L, Söderkvist P and Gimm O (2015). Activating FGFR1 mutations in sporadic pheochromocytoma. Manuscript. 
Publications outside the thesis:

Stenman A, Svahn F, Welander J, Gustavson B, Söderkvist P, Gimm O and Juhlin CC (2015). Immunohistochemical NF1 analysis does not predict NF1 gene mutation status in pheochromocytoma. Endocrine Pathology, 26: 9-14.

Dutta RK, Welander J, Brauckhoff M, Walz M, Alesina P, Arnesen T, Söderkvist P and Gimm O (2014). Complementary somatic mutations of KCNJ5, ATP1A1, and ATP2B3 in sporadic aldosterone producing adrenal adenomas. Endocrine-Related Cancer, 21: L1-4.

Kugelberg J, Welander J, Schiavi F, Fassina A, Bäckdahl M, Larsson C, Opocher G, Söderkvist P, Dahia PL, Neumann HP and Gimm O (2014). Role of SDHAF2 and SDHD in von Hippel-Lindau associated pheochromocytomas. World Journal of Surgery, 38: 724-732.

Jerhammar F, Johansson AC, Ceder R, Welander J, Jansson A, Grafström RC, Söderkvist P and Roberg K (2014). YAP1 is a potential biomarker for cetuximab resistance in head and neck cancer. Oral Oncology, 50: 832-839.

Welander J, Garvin S, Bohnmark R, Isaksson L, Wiseman RW, Söderkvist P and Gimm O (2013). Germline SDHA mutation detected by next-generation sequencing in a young index patient with large paraganglioma. Journal of Clinical Endocrinology and Metabolism, 98: E1379-1380.

Welander J, Söderkvist P and Gimm O (2013). The NF1 gene: a frequent mutational target in sporadic pheochromocytomas and beyond. Endocrine-Related Cancer, 20: C13-17.

Tillmar AO, Dell'Amico B, Welander J and Holmlund G (2013). A universal method for species identification of mammals utilizing next generation sequencing for the analysis of DNA mixtures. Plos One, 8: e83761.

Kling D, Welander J, Tillmar A, Skare O, Egeland T and Holmlund G (2012). DNA microarray as a tool in establishing genetic relatedness - Current status and future prospects. Forensic Science International. Genetics, 6: 322-329.

Welander J, Söderkvist P and Gimm O (2011). Genetics and clinical characteristics of hereditary pheochromocytomas and paragangliomas. Endocrine-Related Cancer, 18: R253276. 


\section{LIST OF ABBRIVIATIONS}

AKT - RAC-alpha serine/threonine-protein kinase

BRCA1 - Breast cancer 1, early onset

cDNA - Complementary deoxyribonucleic acid

CpG - Cytosine-phosphate-Guanine

ddNTP - Di-deoxynycleosidetriphosphate

DNA - Deoxyribonucleic acid

dNTP - Deoxynucleosidetriphosphate

E. coli-Escherichia coli

EGLN - Egl nine homolog

FGF - Fibroblast growth factor

FGFR - Fibroblast growth factor receptor

FH - Fumarate hydratase

FRS2 - Fibroblast growth factor receptor substrate 2

GISTs - Gastrointestinal stromal tumors

HIF - Hypoxia-inducible factor

IDH - Isocitrate dehydrogenase

KIF1B - Kinesin family member 1B

LOH - Loss of heterozygosity

MAD - Max dimerization protein 1

MAPK - Mitogen-activated protein kinase

MAX - Myc-associated factor X

MEK - Dual specificity mitogen-activated protein kinase kinase

MEN1 - Multiple endocrine neoplasia type 1

MEN2 - Multiple endocrine neoplasia type 2

mRNA - Messenger ribonucleic acid

mTOR - Mechanistic target of rapamycin/mammalian target of rapamycin

MXD1 - Max dimerization protein 1

MYC - Myc proto-oncogene protein

NF1 - Neurofibromatosis type 1

PCR - Polymerase chain reaction

PGL 1-4 - Familial pheochromocytoma and paraganglioma syndrome 1-4

PHD - Prolyl hydroxylase domain-containing protein 
PI3K - Phosphatidylinositol-4,5-bisphosphate 3-kinase

PNMT - Phenylethanolamine N-methyltransferase

RAF - Raf (rapidly accelerated fibrosarcoma) proto-oncogene serine/threonine-protein kinase

RAS - GTPase Ras (rat sarcoma)

RET - Proto-oncogene tyrosine-protein kinase receptor Ret (rearranged during transcription)

RNA - Ribonucleic acid

SDH - Succinate dehydrogenase

SDHx - SDHA, SDHB, SDHC, SDHD and SDHAF2

SNP - Single nucleotide polymorphism

TERT - Telomerase reverse transcriptase

TET - Ten-eleven translocation methylcytosine dioxygenase

TMEM127 - Transmembrane protein 127

VEGFA - Vascular endothelial growth factor A

VHL - Von Hippel-Lindau disease

WHO - World Health Organization

X-gal - 5-bromo-4-chloro-3-indolyl- $\beta$-D-galactopyranoside 


\section{BACKGROUND}

\subsection{Cancer - a disease of the genome}

Cancer is the result of a multistep process, in which somatic cells acquire the ability of uncontrolled reproduction through successive genetic and epigenetic alterations ${ }^{1}$. Normally, cells in a multicellular organism are strictly regulated by extracellular signals that direct them to grow, divide, differentiate or die depending of the needs of the whole organism. A random mutation that disturbs these control mechanisms may give a cell a selective advantage that allows it to survive better and proliferate faster than its neighbours. In consistency with Darwinian evolution principles, such a mutation will be favoured in the natural selection, enabling cells that carry the mutation to eventually dominate the local tissue environment. To prevent mutant clones from growing at the expense of their neighbours and eventually kill the organism; the body has several complementary defence mechanisms. Tumor development therefore generally requires alterations in many different control functions and can be seen as a microevolutionary process that occurs during several years or decades. The occurrence of random mutations cannot be avoided, but the process can be affected by environmental factors that may differ between different tumor forms. For example, it can be accelerated by exposure to radiation or carcinogenic chemicals that induce DNA damage. Individuals may also have a hereditary predisposition, i.e. inherited genetic variants that increase the risk of developing tumors in certain tissues.

There are several characteristics that distinguish tumor cells from normal cells. These have been referred to as hallmarks of cancer, ${ }^{2}$, and include the abilities to sustain proliferative signaling, evade growth suppressors, resist cell death, enable unlimited replication and induce angiogenesis. For a benign tumor to turn into a malignancy, a cancer, the cells also need to acquire the ability to invade surrounding tissue. This allows them to enter the blood or lymphatic systems and to form secondary tumors, called metastases, in distant tissues of the body. The acquirement of the above alterations can be accelerated by genome instability, which is a common characteristic of several human tumor forms. For example, tumor cells often have a high mutation rate caused by alterations in DNA repair mechanisms, or an inability to maintain the number or integrity of their chromosomes. Inflammation is another factor which can promote tumor growth by contributing to the acquirement of cancer hallmarks, for example by supplying growth factors. Two additional capabilities that have recently been suggested as cancer hallmarks are the ability to evade destruction by the immune system and the ability to reprogram the cellular energy metabolism ${ }^{3}$. The latter characteristic was originally indicated many decades ago, when Otto Warburg observed that cancer cells can limit their energy metabolism largely to glycolysis even in the presence of oxygen $^{4}$ (a switch referred to as the Warburg effect), as has also been documented by a high glucose uptake by many human tumor types ${ }^{3}$.

When somatic alterations accumulate in tumor cells, multiple alterations also occur that do not have any driving role in the tumor development; these are called passenger mutations. The genetic changes that do contribute to tumorigenesis, the driver events, target two main classes of genes: proto-oncogenes that have normal functions that promote cell survival, growth and 
proliferation; and tumor suppressor genes which have normal functions that counteract the same processes. A gain-of-function mutation that causes overactivation or overexpression of one copy of a proto-oncogene has a dominant growth-promoting effect on the cell. In contrast, both copies of a tumor suppressor gene normally need to be inactivated before any tumorpromoting effect is seen $^{5,6}$. Common genetic alterations in tumor cells include point mutations (including missense, nonsense, frameshift and splice-site mutations), amplifications, deletions and other structural events such as translocations. In addition to changes in the DNA sequence, epigenetic alterations such as DNA methylation and histone modifications also play an important role in tumor development ${ }^{7,8}$. For example, methylation of gene promoters is associated with gene silencing and is commonly observed in tumor suppressor genes.

\subsection{Pheochromocytoma and paraganglioma}

Pheochromocytomas and paragangliomas are tumors that arise from the neuroendocrine cells of the adrenal medulla and the extra-adrenal paraganglia, respectively. These cells have their origin in the embryonic neural crest, which also gives rise to neurons and glial cells of the peripheral, autonomic and enteric nervous systems as well as to melanocytes ${ }^{9}$. As defined by the World Health Organization (WHO), a pheochromocytoma is a tumor of the chromaffin cells of the adrenal medulla ${ }^{10}$. The normal function of these cells is to synthesize and secrete catecholamines, mainly epinephrine (adrenaline) and norepinephrine (noradrenaline) to the bloodstream in response to stimulation by nerve impulses, as a part of the body's fight-orflight response. The name pheochromocytoma, which in Greek means “dark-colored-tumor”, was derived from a color change of the tissue when stained with chromium salts. The extraadrenal counterparts of pheochromocytomas, which are more rare, are called paragangliomas and have their origin in the paraganglia. Paraganglia are small organs of neuroendocrine cells that can be divided into two types ${ }^{10,11}$. Sympathetic paraganglia, consisting of chromaffin cells like the adrenal medulla, are associated with the sympathetic nervous system, lie in the pelvis, abdomen or chest (Figure 1) and can secrete catecholamines in response to neural stimulation. Parasympathetic paraganglia are histologically similar but are located along nerves of the parasympathetic nervous system in the head and neck regions (Figure 1). They consist of clusters of glomus cells, which are cells that have a chemoreceptor role and are involved in regulating the body's cardiac, vascular and respiratory responses to oxygen pressure $^{11,12}$.

Pheochromocytomas and sympathetic paragangliomas often produce abnormally high amounts of epinephrine and/or norepinephrine and cause elevated blood pressure, hypertension ${ }^{13}$. The symptoms are typically recurring episodes of headache, palpitations and sweating, and may also include anxiety, nausea, pallor, tremors and chest or abdominal pain. In some cases, the tumors may cause severe and potentially life-threatening cardiovascular and neurological complications such as shock, heart failure, seizures and stroke $\mathrm{e}^{14-16}$. Parasympathetic paragangliomas do usually not secrete catecholamines and many patients are therefore without symptoms ${ }^{17,18}$, but, depending on the site, the space occupied by the tumors may cause symptoms such as pain, hearing disturbances and hoarseness ${ }^{10}$. 
Pheochromocytomas and paragangliomas are rare tumors with an estimated life-time prevalence of between 1:6500 and 1:2500 ${ }^{19}$. Autopsy studies have revealed a higher prevalence of about 1:2000, suggesting that many tumors remain undiagnosed, and may have contributed to the death of the patients ${ }^{20,21}$. The tumors can occur in all ages but have the highest incidence between the ages of 40-60 years, and are approximately equally common in men and women ${ }^{17,22}$. The majority of pheochromocytomas and paragangliomas are benign, but about $10-15 \%$ are malignant and can develop metastases to unrelated tissue such as bone, liver, lungs and lymph nodes ${ }^{23}$. WHO has defined malignancy in pheochromocytomas and paragangliomas as the presence of distant metastases, and local invasion is thus not sufficient to call a tumor malignant ${ }^{10}$. There are currently no histological or molecular markers to predict malignancy in pheochromocytomas and paragangliomas ${ }^{24}$, except for the presence of a germline mutation in the $S D H B$ gene which increases the risk ${ }^{25}$. The prognosis of malignant tumors is poor, with a 5 -year mortality rate of approximately $50 \%{ }^{24,26}$. There is no curative treatment, though surgery, chemotherapy and radiotherapy are beneficial in some patients. However, thanks to the increasing knowledge of the molecular mechanisms involved in the tumors, new targeted therapies are now under development and testing ${ }^{24,27}$.

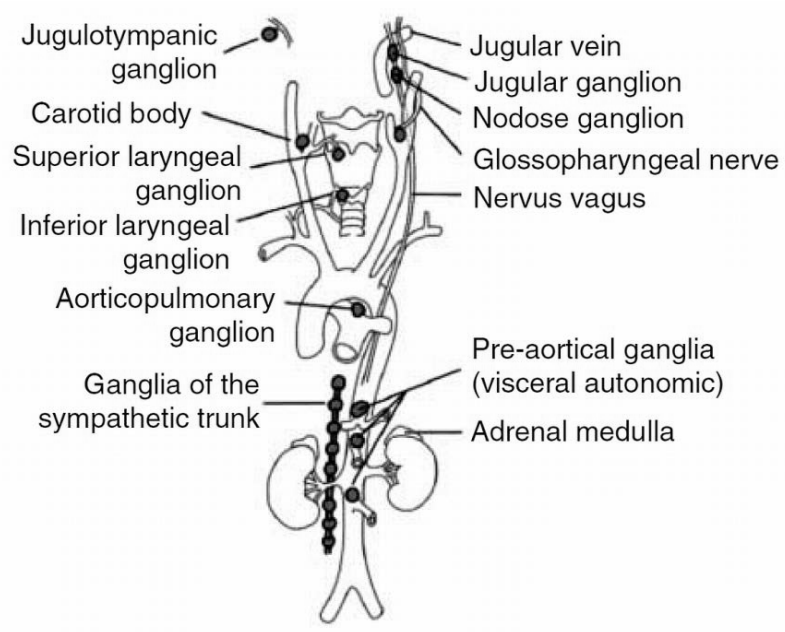

Figure 1. Anatomical distribution of human paraganglia, which consist of neuroendocrine cells derived from the embryonic neural crest. Pheochromocytomas arise in the medulla of the adrenal gland. Sympathetic paragangliomas arise along the sympathetic chains of the chest, abdomen and pelvis, whereas parasympathetic paragangliomas arise along the parasympathetic nerves in the head and neck regions. The figure has been adapted from Lips et al., $2006^{28}$ with permission.

\subsubsection{Hereditary predisposition}

Historically, about $10 \%$ of pheochromocytomas and paragangliomas were known to be associated with hereditary tumor syndromes, mainly multiple endocrine neoplasia type 2 (MEN2), von Hippel-Lindau-disease (VHL) and neurofibromatosis type 1 (NF1) ${ }^{29}$. During the last 15 years, starting with the identification of succinate dehydrogenase (SDH) mutations 
in year $2000^{30}$, it has been revealed that more than a third of the tumors are in fact caused by germline mutations ${ }^{23}$. This makes them the human neoplasms with the highest degree of heritability. We now know that there are at least a dozen different susceptibility genes, which are briefly described below (previously reviewed in more detail by the author and colleagues ${ }^{31}$ and by others ${ }^{23,27}$ ). The genes and syndromes are summarized in Table 1.

\section{RET}

The $R E T$ gene is a proto-oncogene encoding a transmembrane receptor tyrosine kinase ${ }^{32}$. The RET protein is required for normal development and maturation, but it is also important in the maintenance of several tissues and is found in many neural crest-derived cells. RET is normally activated through binding of one of its ligands (proteins from the glial cell linederived neurotrophic factor family), which induces dimerization and autophosphorylation. This leads to activation of multiple downstream pathways, including the RAS/RAF/MAPK and PI3K/AKT pathways ${ }^{32-35}$ (further discussed in section 3.4). Gain-of-function mutations in $R E T$ is the genetic cause of the MEN2 syndrome, which is an autosomal dominantly inherited disorder characterized by medullary thyroid carcinoma and often also pheochromocytoma ${ }^{36}$. Inactivating mutations in RET instead predispose for Hirchsprung disease.

VHL

VHL is a tumor suppressor gene which is involved in oxygen-dependent regulation of hypoxia-inducible factor (HIF) as part of the E3 ubiquitin ligase complex ${ }^{37,} 38$ (further discussed in section 3.3). Germline inactivating mutations in VHL result in the tumor syndrome VHL. It is an autosomal dominantly inherited disease which is characterized by several different tumor forms, including clear cell renal carcinomas, pheochromocytomas/ paragangliomas, hemangioblastomas, pancreatic islet cell tumors and lymphatic sac tumors ${ }^{39}$. Pheochromocytomas occur in about $10-30 \%$ of the cases, but the risk varies between different families.

\section{NF1}

The NF1 gene encodes the tumor suppressor neurofibromin which is expressed in many cell types, but most highly in the cells of the nervous system ${ }^{40,41}$. It promotes the conversion of RAS into its inactive form and thereby suppresses cell proliferation by inhibiting the RAS/RAF/MAPK signaling cascade ${ }^{42,43}$. It has also been shown to inhibit PI3K/AKT/mTOR signaling via its suppression of RAS ${ }^{44,45}$. Inactivating mutations in NF1 cause NF1 syndrome, also called von Recklinghausen's disease ${ }^{40}$. It is inherited as an autosomal dominant disease, but about half of the patients have de novo mutations since the large NF1 gene has one of the highest spontaneous mutation rates in the human genome. The diagnosis criteria for NF1 include neurofibromas, café au lait patches, skin fold freckling, iris Lish nodules, optic pathway gliomas and bone dysplasia. The patients are also predisposed to develop malignant peripheral nerve sheath tumors, other gliomas and cognitive impairment. Pheochromocytoma and paraganglioma are not among the most common manifestations (occurring only in 0.1$5.7 \%$ of the patients ${ }^{46}$ ) but are considerably more common than in the general population. Due to the typical and early symptoms, NF1 is usually diagnosed in childhood and genetic testing is normally not required ${ }^{40}$. 
SDHx

$\mathrm{SDH}$ is an enzyme complex which is also known as mitochondrial complex $\mathrm{II}^{47}$. It is involved in the tricarboxylic acid cycle, where it catalyzes the oxidation of succinate to fumarate, and also in the respiratory electron transfer chain, where it transfers electrons to coenzyme Q. SDH consists of four subunits which are all encoded by the nuclear genome: SDHA, SDHB, SDHC and SDHD. SDHA functions as part of the catalytic domain. SDHB forms the other part of the catalytic domain and also constitutes an interface with the membrane anchor. The anchor is built up of the two hydrophobic proteins SDHC and SDHD, which attach the complex to the mitochondrial inner membrane. The complex has been shown to have a tumor suppressor role, and inactivating germline mutations in the encoding genes cause syndromes of familial pheochromocytoma and paraganglioma termed PGL 1-4. This was first discovered for $S D H D^{30}$ followed by $S D H C^{48}$ and $S D H B^{49}$, in which mutations were shown to cause the syndromes PGL1, PGL3 and PGL4, respectively. Later on it was revealed that mutations in SDHAF2, encoding a cofactor required for the assembly of the complex, were responsible for the PGL2 syndrome ${ }^{50}$. The syndromes are inherited in an autosomal dominant manner but PGL1 and PGL2 are almost exclusively passed on from fathers, suggesting that SDHD and $S D H A F 2$ are maternally imprinted ${ }^{51,52}$. Most recently it was discovered that the fourth subunit of the complex, SDHA, is also involved in pheochromocytoma and paraganglioma, although the penetrance of the disease appears to be lower for mutations in SDHA than in the other genes $^{53}$. Inactivation of any of the different $S D H x$ genes has been shown to abolish the SDH enzyme activity ${ }^{54}{ }^{55}$ and lead to an absence of the SDHB protein, as can be detected by immunohistochemistry of the tumor tissue ${ }^{56-58}$. A recent study also demonstrated that $\mathrm{SDHx}$ mutated tumors can be distinguished from other tumors by their high succinate:fumarate ratios $^{59}$. Apart from pheochromocytomas and paragangliomas, mutations in the different $S D H x$ genes have been shown to be involved in some other tumor forms (sometimes cooccurring with pheochromocytoma/paraganglioma), including renal cell carcinoma ${ }^{60}$, thyroid carcinoma $^{60}$, pituitary adenoma ${ }^{61,62}$ and gastrointestinal stromal tumors (GISTs) ${ }^{63,64}$. The $S D H B$ gene is of special interest since patients with $S D H B$ mutations have a considerably higher risk of developing metastases, and hence a much worse prognosis, than other pheochromocytoma and paraganglioma patients ${ }^{25}$. The mechanisms behind this are still largely unknown, but epigenetic reprogramming (further discussed in section 3.2.3) may constitute part of the explanation ${ }^{65}$.

\section{TMEM127}

The TMEM127 gene encodes a transmembrane protein that has been demonstrated to function as a tumor suppressor and a negative regulator of mTOR as well as a pheochromocytoma susceptibility gene ${ }^{66}$. Subsequent studies showed that germline TMEM127 mutations are present in about $1-2 \%$ of pheochromocytomas and paragangliomas without known mutations in other susceptibility genes ${ }^{67,68}$. They occur predominantly in pheochromocytomas and only rarely in paragangliomas ${ }^{69}$. In a large family, pheochromocytomas occurred in $32 \%$ of the individuals who carried TMEM127 mutations $^{70}$. TMEM127 mutations have also been identified in patients with renal cell carcinoma ${ }^{71}$.

MAX

MAX is a transcription factor that plays an important role in regulation of cell proliferation, differentiation and death in the MYC/MAX/MXD1 network, which is involved in the 
development of several cancers ${ }^{72}$. Heterodimerization of MAX with MYC family members results in sequence-specific DNA-binding complexes that act as transcriptional activators of genes that promote growth and proliferation. Heterodimers of MAX with MXD1 (also known as MAD) antagonize MYC-MAX function by repressing transcription of the same target genes. PC12 cells, which are derived from a rat pheochromocytoma ${ }^{73}$, have been observed to only express a mutant form of $\mathrm{MAX}^{74}$. Reintroduction of normal MAX inhibited growth, suggesting that MAX might work as a tumor suppressor. This was confirmed many years later when inactivating germline mutations were discovered in pheochromocytomas ${ }^{75}$. A large subsequent study established that germline $M A X$ mutations are responsible for just over $1 \%$ of pheochromocytomas/paragangliomas that lack mutations in other susceptibility genes ${ }^{76}$. MAX mutations have been observed both in cases with and without family history of pheochromocytoma and the prevalence is thus unknown ${ }^{75,76}$. So far, no other tumor forms are known to be associated with $M A X$ mutations.

\section{EPAS1}

The EPAS1 gene encodes HIF- $2 \alpha$ which, like HIF- $1 \alpha$, is a transcription factor involved in the cellular hypoxic response ${ }^{77,78}$. Germline EPAS1 mutations have been found in rare patients with polycythemia, a disease state characterized by an abnormal increase in the concentration of red blood cells ${ }^{79}$. In rare cases such patients may also have mutations in VHL and EGLN1, which are also involved in the hypoxic response. In 2012, it was discovered that gain-offunction mutations in EPAS1 are the cause of a syndrome characterized by both polycythemia and paraganglioma, thus presenting the first evidence of EPAS1 as a proto-oncogene ${ }^{80}$. The mutations were somatic and not present in the germline, but they are thought to occur during early development and thereby cause mosaicism for the mutation in the adult ${ }^{81,82}$. A subsequent study revealed a germline EPAS1 mutation in a patient with polycythemia and paraganglioma $^{83}$. Both this and the previously identified somatic mutations were demonstrated to increase the stability of HIF-2 $\alpha$, and another study showed that EPAS1 mutations promote tumor growth in mice ${ }^{84}$. So far, all the identified somatic mutations occurred in or in close vicinity of Pro531 in exon 12, which is the primary hydroxylation site of HIF- $2 \alpha^{78}$. In contrast, the germline mutation occurred in exon 9, closer to Pro405 which is the second of the two hydroxylation sites. In addition to polycythemia and paragangliomas, some EPAS1 patients also have somatostatinomas, which are rare tumors of the pancreas ${ }^{85}$.

\section{$\mathrm{FH}$}

In 2013, a germline mutation was for the first time identified in the $F H$ gene in a pheochromocytoma patient ${ }^{65}$. The mutation was coupled with a somatic mutation in the other allele in the tumor, in agreement with a tumor suppressor role. $F H$ encodes fumarate hydratase, another enzyme in the tricarboxylic acid cycle which catalyzes the conversion of fumarate to malate. Germline FH mutations that reduce the fumarate hydratase activity are since previously known to predispose to smooth muscle tumors of the uterus and the skin and to papillary renal cell cancer ${ }^{86}$. Additional such mutations were later found in about $0.8 \%$ of pheochromocytoma/paraganglioma patients without other susceptibility gene mutations, including one patient who also had uterine tumors ${ }^{87}$. Though rare, mutations in $F H$ may be of prognostic significance as they appear to confer a high risk for metastases similar to that of SDHB mutations. 


\section{EGLN1 and EGLN2}

The EGLN1 gene has been implicated in a few cases of paraganglioma. It encodes the protein EGLN1, also known as PHD2, which is a prolyl hydroxylase that catalyzes the proline hydroxylation of HIF- $\alpha^{37}$. EGLN2 and EGLN3 (also known as PHD1 and PHD3) are other HIF prolyl hydroxylases, but EGLN1 appears to be the main enzyme under conditions of normal oxygen levels ${ }^{88}$. Germline mutations in EGLN1 had previously been reported in polycythemia, but not in association with tumors ${ }^{89}$. In 2008 a germline EGLN1 mutation was identified in a patient with polycythemia and recurrent paraganglioma, with loss of the wildtype allele in the tumors suggesting a tumor suppressor role ${ }^{90}$. No mutations in EGLN1, EGLN2 or EGLN3 were detected in a subsequent study of 82 paraganglioma patients ${ }^{91}$ so the prevalence of EGLN mutations remains unknown. However, interestingly, a recent study of patients with polycythemia and multiple pheochromocytomas and paragangliomas reported an additional novel germline EGLN1 mutation in one patient and, for the first time, a germline EGLN2 mutation in another patient ${ }^{92}$.

\section{$K I F 1 B \beta$}

In a few cases, germline mutations in the gene $K I F 1 B$ have been indentified in pheochromocytomas ${ }^{93,94}$, but so far the prevalence of KIF1B mutations in pheochromocytoma/paraganglioma patients is unknown. The gene has two splice variants, $K I F 1 B \alpha$ and $K I F 1 B \beta$, which encode kinesins that share a common region but have different cargo domains for transporting mitochondria and synaptic vesicle precursors, respectively ${ }^{95,}{ }^{96}$. KIF $1 B \beta$ is the splice variant that has been associated with pheochromocytoma and also with neuroblastoma, a childhood cancer that arises from immature neural crest-derived cells ${ }^{93}$, ${ }^{44}$. Studies indicate that $K I F 1 B \beta$ is a tumor suppressor which is necessary for neuronal apoptosis during embryogenesis $^{93,97}$. One model proposes that mutations in $K I F I B \beta$ as well as other pheochromocytoma- and paraganglioma-related genes allow neuronal progenitor cells to escape from neuronal apoptosis (which otherwise occurs during early development when nerve growth factor becomes limiting), and that these cells are capable of forming neural crest-derived tumors later in life ${ }^{93,98,99}$.

\section{Other susceptibility genes}

One study has reported a germline inactivating mutation in BAP1 in a family with uveal and cutaneous malignant melanoma and, in one patient, a paraganglioma ${ }^{100}$. BAP1 encodes a tumor suppressor called BRCA1-associated protein 1, which is a deubiquitinating enzyme that binds to BRCA $1^{101}$. Germline BAP1 mutations have previously been identified in families with uveal and cutaneous malignant melanoma and mesothelioma ${ }^{102-104}$. It is unclear whether the BAP1 mutation was contributing to the paraganglioma development in the case mentioned above, but loss of the wild-type allele in the tumor may support its involvement ${ }^{100}$.

Pheochromocytomas have also been reported in rare patients with multiple endocrine neoplasia type 1, caused by mutations in the MEN1 gene, but it is still unknown whether any causative association exists ${ }^{105}$. 
Table 1. Summary of the clinical presentation for pheochromocytomas and paragangliomas associated with known germline mutations.

\begin{tabular}{|c|c|c|c|c|c|c|}
\hline Gene & Syndrome & $\begin{array}{l}\text { Propor- } \\
\text { tion of all } \\
\text { pheo/para } \\
\text { cases [\%] }\end{array}$ & $\begin{array}{l}\text { Penetrance } \\
\text { of pheo/ } \\
\text { para [\%] }\end{array}$ & $\begin{array}{l}\text { Common } \\
\text { presentation }\end{array}$ & $\begin{array}{l}\text { Risk of } \\
\text { malignancy } \\
\text { (metastasis) }\end{array}$ & $\begin{array}{l}\text { Other conditions } \\
\text { associated with } \\
\text { mutations }\end{array}$ \\
\hline$R E T$ & MEN2 & 5.3 & $\sim 50$ & Pheo, multiple & Low & $\begin{array}{l}\text { Medullary thyroid } \\
\text { carcinoma, } \\
\text { hyperparathyroidism }\end{array}$ \\
\hline VHL & VHL & 9.0 & $10-30$ & $\begin{array}{l}\text { Pheo > Para, } \\
\text { multiple }\end{array}$ & Low & $\begin{array}{l}\text { Renal cell carcinoma } \\
\text { and hemangioblast- } \\
\text { omas, among others }\end{array}$ \\
\hline NF1 & NF1 & 2.9 & $0.1-5.7$ & Pheo, single & Moderate & $\begin{array}{l}\text { Neurofibromas and } \\
\text { gliomas, among } \\
\text { others }\end{array}$ \\
\hline$S D H D$ & PGL1 & 7.1 & $\sim 86^{\mathrm{c}}$ & $\begin{array}{l}\text { Para > Pheo, } \\
\text { multiple }\end{array}$ & Low & $\begin{array}{l}\text { GISTs and pituitary } \\
\text { adenomas }\end{array}$ \\
\hline SDHAF2 & PGL2 & $<1$ & $\sim 100^{\mathrm{c}}$ & Para, multiple & $\mathrm{U}$ & None reported \\
\hline SDHC & PGL3 & $<1$ & $\mathrm{U}$ & Para, multiple & Low & GISTs \\
\hline$S D H B$ & PGL4 & 5.5 & 77 & $\begin{array}{l}\text { Para > Pheo, } \\
\text { multiple }\end{array}$ & High & $\begin{array}{l}\text { GISTs and renal cell } \\
\text { carcinoma }\end{array}$ \\
\hline SDHA & PGL5 & $<3$ & $\mathrm{U}$ & $\begin{array}{l}\text { Para > Pheo, } \\
\text { single }\end{array}$ & $\mathrm{U}$ & GISTs \\
\hline TMEM127 & - & $1-2$ & $\sim 32$ & $\begin{array}{l}\text { Pheo, single/ } \\
\text { multiple }\end{array}$ & Low & Renal cell carcinoma \\
\hline MAX & - & $1-2$ & $\mathrm{U}$ & $\begin{array}{l}\text { Pheo > Para, } \\
\text { single/multiple }\end{array}$ & $\mathrm{U}$ & None reported \\
\hline EPAS1 $^{a}$ & & $<1$ & $\mathrm{U}$ & $\begin{array}{l}\text { Para }>\text { Pheo, } \\
\text { multiple }\end{array}$ & $\mathrm{U}$ & $\begin{array}{l}\text { Polycythemia and } \\
\text { somatostatinomas }\end{array}$ \\
\hline FH & - & $<1$ & $\mathrm{U}$ & $\begin{array}{l}\text { Pheo and Para, } \\
\text { multiple }\end{array}$ & $\operatorname{High}^{\mathrm{d}}$ & $\begin{array}{l}\text { Uterine and skin } \\
\text { leiomyomata, } \\
\text { papillary renal cell } \\
\text { cancer }\end{array}$ \\
\hline$E G L N 1^{b}$ & - & $<1$ & $\mathrm{U}$ & $\begin{array}{l}\text { Pheo and Para, } \\
\text { multiple }\end{array}$ & $\mathrm{U}$ & Polycythemia $^{\text {b }}$ \\
\hline$K I F 1 B \beta^{b}$ & - & $<1$ & $\mathrm{U}$ & Pheo, multiple & U & Neuroblastoma $^{\mathrm{b}}$ \\
\hline
\end{tabular}

The statistics were summarized from the papers reviewed herein and in previously published reviews ${ }^{23,31}$. Pheo, Pheochromocytoma; Para, Paraganglioma; U, unknown; GISTs, Gastrointestinal stromal tumors.

${ }^{a}$ Only a few germline mutations have been reported; the syndrome is more commonly caused by somatic mutations that arise early in embryogenesis. ${ }^{b}$ Only 2-3 patients with mutations have been reported. ${ }^{c}$ Valid only for paternally inherited mutations, penetrance after maternal transmission is approximately 0 , putatively due to maternal imprinting. ${ }^{\mathrm{d}}$ The risk appears to be high ( $~ 50 \%$ of published cases) but the number of reported cases is still low.

\subsubsection{Sporadic tumors}

Sporadic pheochromocytomas and paragangliomas are generally characterized by a somewhat higher age of onset and a lower rate of multiple tumors than the familial cases ${ }^{31}$. In patients with negative family history, the frequency of germline mutations has been reported to be between $5 \%$ and $24 \%$, but closer to the lower number in patients without any syndromic features and with only a single tumor ${ }^{106-111}$. 
Although the proportion of pheochromocytomas and paragangliomas associated with a known germline mutation and/or syndrome has been growing with the discovery of new genes during the recent years, the majority of the tumors are still apparently sporadic, i.e. non-familial and without syndromic features or known germline mutations. While the familial pheochromocytomas and paragangliomas are becoming increasingly well defined, less has been found regarding the genetics of the sporadic tumors, and this was especially the case at the time when this thesis project was initialized in 2010. However, a known feature of both the familial and sporadic tumors is their chromosomal instability, with many large gains and losses ${ }^{112-114}$. For example, somatic loss of the chromosome arms $1 p$ and $3 q$ are very common in sporadic pheochromocytoma, but it is not yet known whether specific tumor suppressor genes in the regions are involved in the pathogenesis.

Somatic mutations in any of the known susceptibility genes have, until recently, been thought to be rare in the sporadic tumors, only occurring in a few percent of the cases ${ }^{29,115-117}$. A later study indicated that somatic VHL and RET mutations were somewhat more common than previously thought ${ }^{118}$, but studies of somatic mutations were still lacking for the more recently discovered genes as well as for the very large NF1 gene.

After the findings of EPAS1 mutations in patients with polycythemia and paraganglioma, subsequent studies identified somatic EPAS1 mutations also in some patients with sporadic pheochromocytoma or paraganglioma but without polycythemia ${ }^{84,119,120}$.

In 2013, somatic activating mutations in HRAS were found in about $7 \%$ of sporadic pheochromocytomas and paragangliomas ${ }^{121}$. Hence, HRAS represents the first gene with recurrent somatic mutations that has not been associated with hereditary pheochromocytoma. RAS proteins are encoded by the three oncogenes HRAS, KRAS and NRAS and constitute components of signaling pathways that start from cell surface receptors ${ }^{122}$ (further discussed in section 3.4). Activating mutations occur in specific residues and are common in a variety of human cancers. The three different genes are mutated to different extent in different tumor types. For example, HRAS mutations have been associated with tumors of the skin whereas KRAS mutations are associated with colorectal tumors and NRAS mutations are common in haematopoetic malignancies. A later study performed mutation analysis of HRAS, KRAS and NRAS and found HRAS mutations in $10 \%$ of sporadic pheochromocytomas, but no association with specific clinical features and no mutations in the other two genes ${ }^{123}$. One study has reported somatic mutations in KRAS in pheochromocytomas, but the results have not been replicated $^{124}$.

In a single case, a somatic mutation in the IDH1 gene has been detected in a sporadic paraganglioma $^{125}$. IDH1 encodes isocitrate dehydrogenase type 1 , which, like succinate dehydrogenase and fumarate hydratase, is a tricarboxylic acid cycle enzyme. Isocitrate dehydrogenase catalyzes the oxidative decarboxylation of isocitrate to $\alpha$-ketoglutarate. Mutations in IDH1 are common in gliomas ${ }^{126,127}$ and also occur in some other cancers ${ }^{128}$.

Recently, the TERT gene was revealed to be involved in a small proportion of pheochromocytomas and paragangliomas ${ }^{129}$. Out of 105 pheochromocytomas and 13 paragangliomas, somatic hotspot TERT promoter mutations were found in one benign 
pheochromocytoma and one metastatic paraganglioma. The gene encodes human telomerase reverse transcriptase, the catalytic subunit of telomerase that maintains genomic integrity through telomere elongation, and it is often upregulated in cancer ${ }^{130}$. Activating hotspot mutations in the TERT promoter have recently been described in several human tumor forms, with the first discoveries being in melanomas ${ }^{131,132}$.

Taken together, our knowledge of sporadic pheochromocytoma and paraganglioma has greatly advanced during the last few years ${ }^{133}$. Still, about half of the sporadic tumors remain without any known genetic driver event ${ }^{134,135}$. The total mutation load in pheochromocytomas and paragangliomas is also largely unknown, as well as whether driver alterations in different genes may co-occur and collectively contribute to the tumorigenesis ${ }^{23}$.

\subsubsection{Hormone profiles, gene expression and epigenetics}

Depending on their genetic background, hereditary pheochromocytomas and paragangliomas are known to show differences in the catecholamines they secrete ${ }^{136}$. Whereas there are no obvious differences in the patients' levels of norepinephrine, epinephrine levels are strongly increased in patients with MEN2 and NF1, but low in patients with VHL or SDHx mutations. In addition, many patients with $S D H x$ mutations have increased levels of dopamine, which are more rare in VHL, MEN2 and NF1 patients. Together with age, tumor location, malignancy and the number of tumors, the secretory phenotype (especially the levels of epinephrine) can be useful for prioritizing the order of genetic testing, as is also recommended in the current clinical practice guidelines from the Endocrine society ${ }^{137}$.

Studies of genome-wide mRNA gene expression have revealed that pheochromocytomas and paragangliomas cluster into two groups based on their transcription profiles ${ }^{118,138-141}$. VHLand $S D H x$-mutated tumors form one cluster (cluster 1), which is enriched for genes involved in the hypoxic response and angiogenesis. In contrast, RET- and NF1-mutated tumors form another cluster (cluster 2) which displays a transcription signature that is associated with activation of kinase signaling and neuroendocrine differentiation. In agreement with the higher levels of epinephrine in MEN2 and NF1 patients, PNMT is one of the genes that has been shown to be overexpressed in cluster 2 tumors $^{118,}{ }^{138}$. The PNMT gene encodes the enzyme phenylethanolamine $\mathrm{N}$-methyltransferase, which catalyzes the methylation of norepinephrine to form epinephrine ${ }^{138}$. When studying the more recently discovered susceptibility genes, tumors with mutations in $K I F 1 B \beta^{94}, T M E M 127^{66,142}$ and $M A X^{75}$ were all observed to cluster with the RET/NF1 group, whereas $S D H A F 2^{143}, S D H A^{53}$ and $F H^{65}$ belong to the SDH/VHL cluster as would be expected. Sporadic tumors are represented in both clusters instead of forming clusters of their own, indicating that similar molecular mechanisms are involved. A recent study showed that expression profiling of microRNAs (which are small non-coding RNA molecules with important roles in modulating gene expression ${ }^{144}$ ), also successfully classifies pheochromocytomas and paragangliomas into one VHL/SDHx cluster and one RET/NF1/TMEM127/MAX cluster $^{145}$.

Hypermethylation of different genes has also been suggested to play a role in pheochromocytoma and paraganglioma development ${ }^{146-149}$. In 2013, it was revealed that tumors with $S D H x$ mutations display genome-wide hypermethylation compared to other 
tumors $^{65}$. The first discovered tumor with $F H$ mutations also had a similar hypermethylator phenotype. The highest degree of hypermethylation occurred in tumors with SDHB mutations, and this may constitute part of the explanation for their high risk of malignancy. It was shown that succinate accumulation due to $S D H x$ mutations inhibited the ten-eleven translocation methylcytosine dioxygenase (TET) enzymes, which catalyze $\alpha$-ketoglutarate-dependent demethylation. Fumarate accumulation due to $\mathrm{FH}$ mutations is thought to have the same effect ${ }^{65}$, 87. The mechanism is similar to the epigenetic reprogramming that takes place in gliomas, where oncogenic mutations in $I D H 1$ or IDH2 instead cause inhibition of the demethylation by promoting production of 2-hydroxyglutarate from $\alpha$-ketoglutarate ${ }^{150,151}$. In all the cases, the inhibited demethylation is suggested to cause a high abundance of DNA methylation with the associated deregulation of multiple genes ${ }^{151,152}$.

\subsection{The hypoxic response}

Tumors belonging to cluster 1 have the common feature of activation of hypoxia-inducible factors (HIFs), which is a consequence of both VHL and SDH inactivation. HIFs are sequence-specific DNA-binding transcription factors that activate several genes that promote adaptation and survival under conditions of hypoxia, i.e. reduced oxygen levels ${ }^{77,153}$. Active HIF is a heterodimer which consists of one $\alpha$ and one $\beta$ subunit. The $\beta$ subunit, HIF- $1 \beta$ or aryl hydrocarbon receptor nuclear translocator, is stably expressed, and HIF activity is therefore mainly regulated by the levels of HIF- $\alpha$. There are three human HIF- $\alpha$ proteins: HIF- $1 \alpha$, HIF$2 \alpha$ and HIF- $3 \alpha$. HIF- $1 \alpha$ is expressed in nearly all cell types ${ }^{78}$, whereas HIF- $2 \alpha$ is mainly expressed in endothelium, heart, lung, kidney, gastrointestinal epithelium and neural crestderived cells ${ }^{154,}{ }^{155}$. HIF-3 $\alpha$ is only expressed in a few organs including the thymus, the corneal epithelium of the eye and the Purkinje neurons of the cerebellum ${ }^{155,156}$. Currently, little is known regarding HIF-3 $\alpha$, whereas HIF-1 $\alpha$ and HIF-2 $\alpha$ (hereafter together referred to as HIF- $\alpha$ ) are more well-characterized. During normal oxygen levels, HIF- $\alpha$ is hydroxylated at two proline residues by prolyl hydroxylases, which are members of the EGLN/PHD family $^{77}$ (Figure 2). The hydroxylation allows HIF- $\alpha$ to be recognized by the E3 ubiquitin ligase complex, which the VHL protein is a part of. This complex ubiquitinates HIF- $\alpha$, and thereby targets it for degradation by the $26 \mathrm{~S}$ proteasome. Since the hydroxylation reaction is dependent on molecular oxygen, it is reduced at low oxygen levels, which results in stabilization of HIF- $\alpha$ and subsequent transcription of a variety of genes involved in angiogenesis, energy metabolism, survival and growth. HIF activation is also well-known to be involved in tumorigenesis and cancer progression ${ }^{37,157,158}$.

If VHL is inactivated by a mutation, HIF- $\alpha$ cannot be ubiquitinated and is thus allowed to accumulate and activate transcription regardless of the oxygen levels, a condition that is known as pseudohypoxia ${ }^{38,159}$. Inactivation of the SDH complex also leads to a pseudohypoxic response since dysfunction of its catalytic activity causes an accumulation of succinate ${ }^{159}$. The succinate can diffuse out from the mitochondrion to the cytosol and has been shown to be a competitive inhibitor of EGLN by blocking the binding site of $\alpha$ ketoglutarate $^{160}$. The EGLN enzyme activity is thus inhibited, resulting in HIF- $\alpha$ stabilization and activation ${ }^{161}$. In a similar way, the prolyl hydroxylation may be inhibited by fumarate accumulation due to $F H$ mutations, as has previously been shown in renal cancer ${ }^{162}$. 


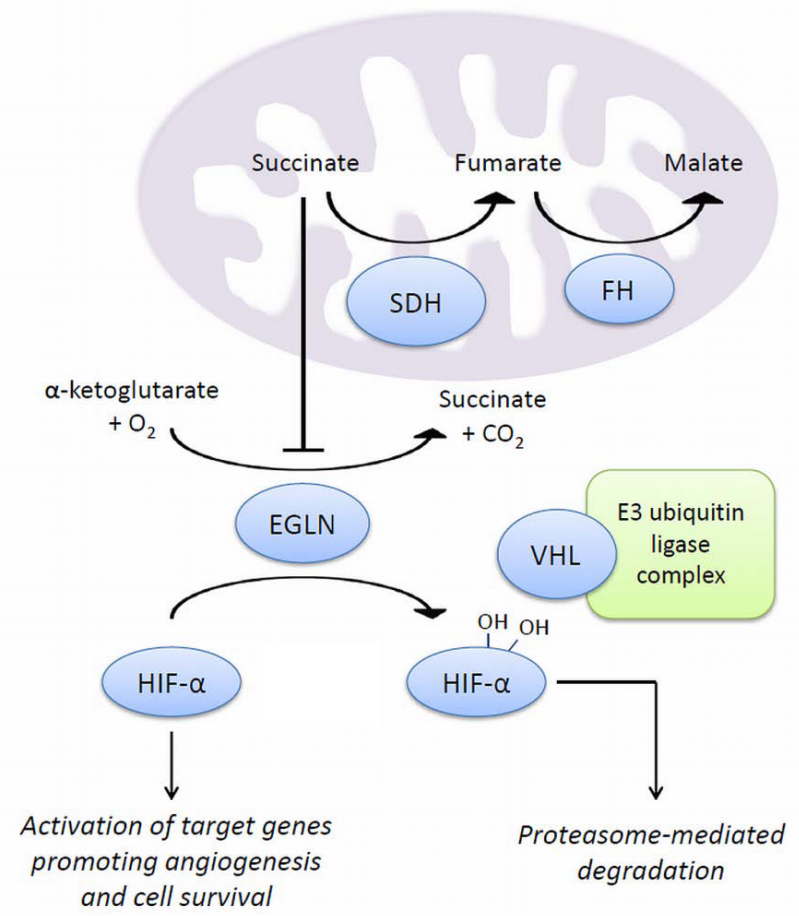

Figure 2. HIF- $\alpha$ regulation and the hypoxic response. EGLN prolyl hydroxylases catalyze the hydroxylation of HIF- $\alpha$ at two proline residues. The hydroxylation allows HIF- $\alpha$ to be recognized and ubiquitinated by the VHL E3 ubiquitin ligase complex, which targets it for proteasome-mediated degradation. During hypoxia, the hydroxylation is reduced and HIF- $\alpha$ is allowed to accumulate and promote transcription. If components in the machinery are inactivated, e.g. by mutations, an aberrant stabilization of HIF- $\alpha$ may occur that is independent of the oxygen levels, a process that is termed pseudohypoxia. HIF- $\alpha$ here refers

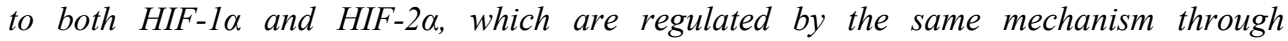
homologous hydroxylation sites. Proteins indicated with blue color have been found to carry mutations in subsets of pheochromocytomas and paragangliomas, including HIF-2 $\alpha$ itself. The figure is an updated version of a previously published figure (Welander et al., 2011 $1^{31}$ ).

HIF- $1 \alpha$ and HIF-2 $\alpha$ have both shared and separate target genes and functions ${ }^{78,155}$, and can even have some opposing effects ${ }^{163}$, but their individual roles in pheochromocytomas and paragangliomas have been unclear. Both proteins have been found to be upregulated in $V H L$ and $S D H x$-mutated pheochromocytomas and paragangliomas ${ }^{54,140,163,164}$. Whereas the role of HIF- $1 \alpha$ remains elusive, definitive evidence of the importance of HIF- $2 \alpha$ was presented when gain-of-function mutations in its gene, EPAS1, were discovered in paragangliomas ${ }^{80}$. The mutations occur in or close to one of the two hydroxylation residues. This allows HIF-2 $\alpha$ to avoid hydroxylation and thereby also to escape ubiquitination and degradation. 


\subsection{The RAS/RAF/MAPK and PI3K/AKT signaling pathways}

In the tumors of cluster 2 , the affected genes are linked by their association with kinase signal transduction pathways. Both oncogenic activation of $\mathrm{RET}^{33-35}$ and inactivation of neurofibromin $^{42-45}$ is known to result in activation of the RAS/RAF/MAPK and PI3K/AKT cascades, which are sometimes interconnected via RAS (Figure 3). Both signaling pathways promote cell proliferation, growth and survival and are frequently dysregulated in human cancers $^{165,166}$. They are normally initiated by ligand binding and subsequent activation of cell surface receptor tyrosine kinases, to which the RET protein belongs. Oncogenic mutations can cause an activation of RET which is independent of extracellular signals. Inactivation of neurofibromin, which normally inhibits RAS by converting it into its inactive form, can result in constantly active RAS signaling, as can activating mutations in RAS itself. Indeed, new evidence for the involvement of RAS in a subset of pheochromocytomas and paragangliomas was presented when activating mutations in $H R A S$ were detected in sporadic tumors ${ }^{121}$.

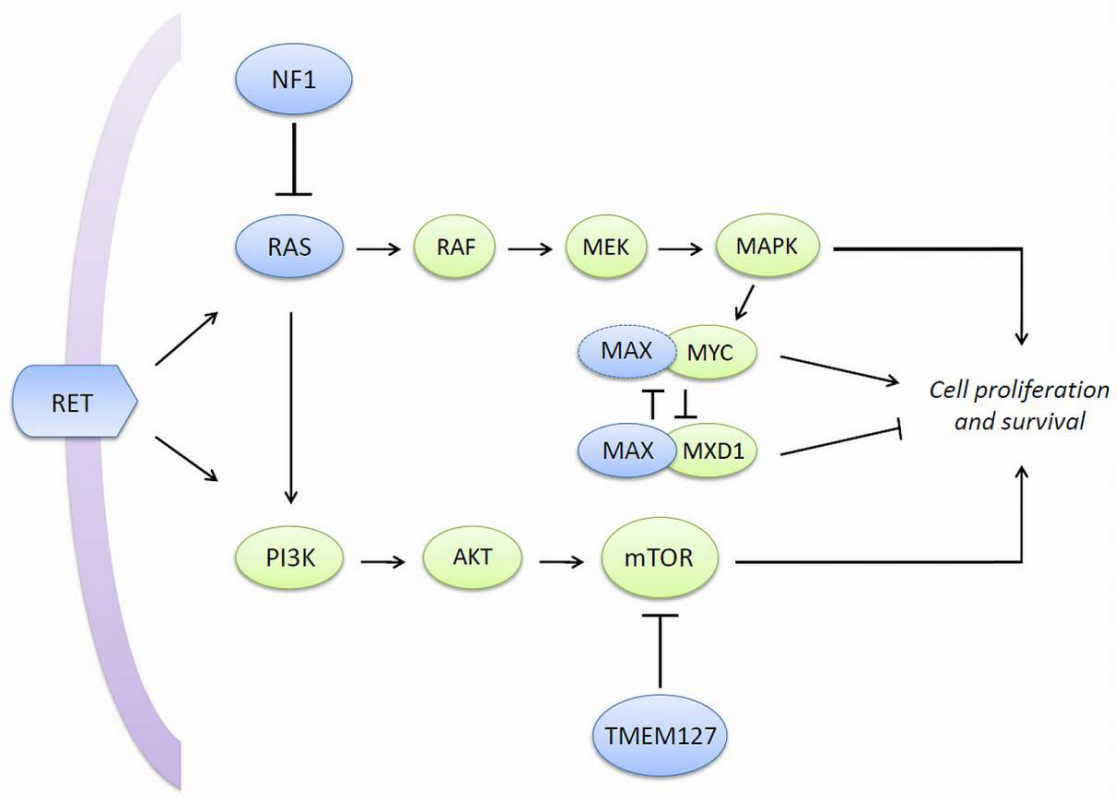

Figure 3. Kinase signaling pathways. Activation of RET or other receptor tyrosine kinases initiate a cascade of events that activate RAS/RAF/MAPK and PI3K/AKT signaling, which affect multiple cellular processes to promote cell proliferation and survival. The NF1 protein, neurofibromin, inhibits RAS by promoting its conversion into its inactive form. TMEM127 is thought to inhibit mTOR signaling which is downstream of AKT. Proteins that have been found mutated in pheochromocytomas and paragangliomas are indicated with blue color. The role of inactivating MAX mutations in tumorigenesis is not yet known, as MAX-MYC dimers promote proliferation whereas MAX-MXD1 dimers inhibit it. Some cross-talk between the $M A X-M Y C$ network and the RAS/RAF/MAPK pathway has been suggested. The figure is an updated version of a previously published figure (Welander et al., $2011^{31}$ ). 
The function of TMEM127 is largely unknown, but it is suspected to inhibit mTOR signaling ${ }^{66}$ which is a downstream effect of AKT signaling. TMEM127 mutations enhanced mTOR activity, possibly suggesting a common feature of mutations in RET, NF1 and TMEM127 that may explain their similar transcription profiles.

Tumors with mutations in $M A X$ appear to form a subcluster within cluster 2 but also share some features with cluster 1 tumors, like a low or intermediate expression of $P N M T^{76,163}$. Links between the MYC/MAX/MXD1 network and the other pathways may exist, for example RAS/RAF/MAPK activation promotes MYC stability ${ }^{167}$ and mTOR activity appears to be required in some MYC-driven cancers ${ }^{168}$.

Although the hypoxic response appears to be mainly associated with cluster 1 pheochromocytomas and paragangliomas whereas the involvement of kinase signaling pathways is more pronounced in cluster 2 tumors, it can be noted that there is probably overlap and crosstalk between the two. For example, HIF signaling can be activated by mTOR $^{169}$, and activation of the RAS/RAF/MAPK and PI3K/AKT pathways has been shown to increase HIF- $\alpha$ signaling in different cancers ${ }^{170-172}$. In addition, HIFs are known to be involved in the regulation of the MYC/MAX/MXD1 network ${ }^{173,174}$.

\subsubsection{Fibroblast growth factor receptors}

Fibroblast growth factor receptors (FGFR1-4) represent other receptor tyrosine kinases that are upstream components of the RAS/RAF/MAPK and PI3K/AKT signaling pathways ${ }^{175}$. Binding of fibroblast growth factors (FGFs) to the receptors induces receptor dimerization which activates the intracellular kinase domain and leads to transphosphorylation. The phosphorylated tyrosine residues function as docking sites for adaptor proteins, for example FRS2, which can be phosphorylated by FGFR. This leads to an activation of signal transduction pathways, including the RAS/RAF/MAPK and PI3K/AKT pathways. FGFRs are involved in the formation of several organ systems during embryonic development and regulate processes such as tissue repair, angiogenesis and inflammation in the adult ${ }^{175,176}$. Mutations in FGFR2, FGFR3 and FGFR4 have been reported in different human tumor forms $^{176}$, of which FGFR3 mutations in bladder cancer are perhaps the most well $\mathrm{known}^{177,178}$. Activation of FGFR1 has mainly been observed in the form of FGFR1 amplification in breast cancer ${ }^{179}$ and lung cancer ${ }^{180}$, and occasional mutations and fusion genes involving FGFR1 have been identified in glioblastomas ${ }^{181}$. Recently, activating hotspot FGFR1 mutations were revealed to be frequent in another form of brain tumor: pilocytic astrocytoma $^{182}$. 


\section{AIMS}

The overall aim of this thesis was to further characterize the genetic background of the neuroendocrine tumor forms pheochromocytoma and paraganglioma.

The specific aims were:

- To investigate the role of the genes known from familial pheochromocytoma and paraganglioma in the sporadic form of the disease

- To study alterations in recently discovered susceptibility genes and their effects on gene expression patterns in pheochromocytoma

- To set up a next-generation sequencing method for analysis of the above genes and evaluate its usefulness for genetic testing of pheochromocytoma and paraganglioma

- To use the knowledge gained from the above experiments in order to search for potential novel genes involved in the tumor development 


\section{MATERIALS AND METHODS}

\subsection{Biological samples}

The samples used in the work of this thesis consisted of tumor tissue and corresponding adjacent normal tissue and/or blood samples from patients with pheochromocytoma or paraganglioma. The tumors were surgically removed between 1986 and 2014 at the Linköping University Hospital, Linköping, Sweden, at the Karolinska University Hospital, Stockholm, Sweden or at the Haukeland University Hospital, Bergen, Norway. In the last study, tumors from Hôpital de Brabois, Nancy, France, were also included. Tumors and corresponding blood samples were snap frozen in liquid nitrogen and stored at $\leq-70^{\circ} \mathrm{C}$. Genomic DNA and total RNA were extracted using standardized methods which involve homogenization of the tissue, cell lysis and binding of the nucleic acids to a spin column membrane, from which they are eluted after washing. For immunohistochemistry and microdissection, tissue samples were fixed in formalin and embedded in paraffin. All samples were collected and studied with informed consent from the participating patients and with approval from the local ethic committees.

\subsection{Capillary Sanger DNA sequencing}

DNA sequencing with chain-termination technology was developed by Frederick Sanger in $1977^{183}$ and has been the most widely used sequencing method for more than two decades. After amplification of the target DNA fragment using the polymerase chain reaction $\left(\mathrm{PCR}^{184}\right)$, a second, similar synthesis reaction is performed in which some of the included deoxynucleosidetriphosphates (dNTPs) are modified into di-deoxynycleosidetriphosphates (ddNTPs) that are labeled with different fluorescent dyes. When a ddNTP is incorporated, the synthesis will terminate because of its inability to form a phosphodiester bond with the next nucleotide. The result of the reaction is a mixture of DNA fragments of different sizes, which can be separated by size using capillary gel electrophoresis. The identity of the terminating nucleotide is detected by the fluorescent emission that follows laser excitation of the fluorescent dye. The Sanger method was used in all the included papers. Primers for PCR and subsequent sequencing were designed using a web-based tool ${ }^{185,}{ }^{186}$. The primers were designed not to overlap with known polymorphisms and were checked for specificity in silico by electronic $\mathrm{PCR}^{187}$. Sequencing results were analyzed by alignment and comparison to the reference sequence and by visual inspection of electropherograms.

\subsection{Next-generation DNA sequencing}

During the last decade, new methods for sequencing have started to replace the traditional Sanger method, especially for large-scale genomic studies. The new technologies, which are collectively known as next-generation sequencing methods, allow massively parallel sequencing of individual molecules in a sample and produce large amounts of data at a low price per base compared to Sanger sequencing ${ }^{188,189}$. The methods are being used in a variety of applications, ranging from genome and transcriptome sequencing of more and more species, metagenomic characterizations and evolutionary studies, to clinical mutation analysis 
of targeted gene panels as well as entire human genomes. In this work, we have used one of the now dominating next-generation sequencing technologies which was developed by Solexa ${ }^{190}$ and then acquired and further developed by Illumina. In this method, the DNA molecules that are to be sequenced are ligated to oligonucleotide adaptors, which then are allowed to bind to complementary adaptors on the surface of a flow cell. An amplification reaction is then performed in the flow cell, in which the surface-bound adaptors function as primers and each of the millions of molecules that are attached to the surface will give rise to a cluster of copies. After this, sequencing reagents are added which include reversibly terminating dNTPs that are labeled with fluorophores. After the incorporation of one nucleotide, the fluorescence is detected across the entire flow cell. The fluorophore is then removed and the termination is reversed to allow for the incorporation and detection of the next nucleotide. The process is referred to as sequencing by synthesis. The result is a series of images capturing the fluorescent signal in each of the millions of clusters. The derived sequences are then identified by alignment against a reference genome. In Paper III, we used a targeted sequencing approach to perform mutation analysis of the known pheochromocytoma and paraganglioma susceptibility genes. We designed probes for simultaneous amplification of all the targeted exons. The amplicons were labeled with Illumina adaptors and also with barcode sequences to allow pooling of many samples. The pool of amplicons was then sequenced on an Illumina MiSeq instrument. In Paper IV, a standardized protocol for enrichment and labeling of the entire human exome was used, followed by sequencing on an Illumina HiSeq instrument. Using established bioinformatics methods ${ }^{191}$, the resulting sequences were aligned to the human reference genome and differences from the reference were called as variants. The variants could then be filtered based on their predicted effect on the protein and overlap with known polymorphisms. For the exome sequencing results, dedicated software tools ${ }^{192,193}$ were used to extract somatic point mutations and indels by comparing the sequences from tumors with those from normal DNA.

\subsection{Quantitative real-time PCR}

Quantitative real-time PCR is a method to measure small amounts of nucleic acids by realtime detection of the progress of a PCR reaction. The number of the PCR cycle in which the amount of product reaches a certain threshold can be used to calculate the starting amount of template in the sample, either relative to endogenous controls or as an exact number of molecules by using a standard curve ${ }^{194,195}$. In Paper I, quantitative real-time PCR was used to measure gene expression. Tumor RNA was first converted into complementary DNA (cDNA) by reverse transcription. We then used pre-designed TaqMan assays from Applied Biosystems, which contain two primers and one sequence-specific probe that can anneal to the template. The probe is bound to a fluorophore and a quencher, and as long as these are close together, the quencher suppresses the fluorescence. If a template is amplified, the fluorophore is cleaved off, resulting in a detectable signal. The expression was measured relative to two reference genes, HPRT1 and GUSB, which were selected based on their stable expression in several different tumor forms ${ }^{196}$ and mean expression levels in the same order of magnitude as the target genes. The data was analyzed according to the comparative $\mathrm{C}_{\mathrm{T}}$ method $^{194}$. 


\subsection{Methylation-specific PCR}

Methylation-specific PCR is a method that can be used to determine the methylation status of certain CpG sites in DNA ${ }^{197}$. The first step of the method is a treatment of the DNA with bisulphite. This converts all cytosine residues into uracil, except for methylated cytosines which are left unaffected. Two sets of primers are then designed, one set that will only detect methylated DNA (containing cytosines at CpG sites) and one set that will specifically detect non-methylated DNA in which all cytosines have been converted to uracil (which base-pairs with adenine) ${ }^{198}$. After the two PCR reactions have been performed separately, gel electrophoresis detection reveals whether a sample contains methylated DNA, non-methylated DNA or both. Methylation-specific PCR was used to investigate promoter methylation in Paper I. The method is limited to the CpG sites that are covered by the designed primers, and newer, more advanced methods that cover CpG sites across the entire human genome are now available $^{199}$.

\subsection{DNA microarrays}

A microarray consists of oligonucleotides that are attached to a surface in a specific pattern, and can be used to detect complementary oligonucleotides in a sample. DNA microarrays can be used to study single nucleotide polymorphisms (SNPs) as well as copy number variations in DNA. In the technology from Affymetrix, which was used in this work, genomic DNA is digested with a restriction enzyme, and adaptors are ligated to the restriction site overhangs ${ }^{200}$. A PCR is then performed using generic primers that recognize the adaptor sequences. The amplified DNA is fragmented and labeled with fluorescence, and thereafter hybridized to the oligonucleotides on a microarray. The array is filled with 25 bases long oligonucleotide probes organized in a pattern of spots, where each spot contains probes with a unique sequence. For each SNP there are probes that match each of the two possible alleles. After washing away unbound sample molecules, the fluorescence is detected in a scanner. The fluorescence intensities represent the amount of hybridization that occurred for each probe, and an algorithm is used to translate these intensities into genotypes ${ }^{201}$. The intensities can also be used to determine the copy number of DNA across the genome ${ }^{202}$. In paper I, we used a microarray from Affymetrix covering approximately 250,000 SNP sites to examine copy number alterations in pheochromocytomas. The copy number calling is always performed in relation to a reference material which is assumed to have a mean of two copies at all autosomal loci ${ }^{202}$. In this case, the reference material consisted of microarray intensity data from 48 individuals of European ancestry from the International HapMap project ${ }^{203}$ that was provided by Affymetrix. To reduce noise in the data, a copy number alteration was only called when $\geq 10$ genetically adjacent markers in a sample showed the same copy number $(\neq 2)$. In Papers II and IV, we reanalyzed the data to investigate copy number alterations in the EPAS1 and FGFR1 genes, respectively.

\subsection{RNA microarrays}

RNA microarrays use the same basic principle as DNA microarrays, but instead of SNP markers, the oligonucleotides on the array are designed to recognize expressed RNA molecules that have been converted to cDNA. The abundance of a specific RNA molecule 
will then be reflected by the fluorescence intensity in the microarray spot where it is detected $^{204}$. In Paper II and Paper IV, we used an Affymetrix microarray for analysis of gene expression levels of 28,869 annotated genes. Each gene is covered by a median of 26 different probes (a probe set) on the array, from which the signals are summarized to calculate a measure of the gene expression. Data was pre-processed using the robust multi-array average algorithm $^{205}$, which includes background correction and normalization. To test for differentially expressed genes between groups of samples, t-tests were performed within dedicated software (GeneSpring GX from Agilent). To reduce the number of false positive results, the Benjamini-Hochberg algorithm was used to correct for multiple testing ${ }^{206}$. Hierarchical clustering was used to visualize the gene expression patterns in different samples. A hierarchical clustering algorithm creates a dendrogram of the analyzed samples based on their similarity ${ }^{207}$. First, it identifies the two samples in the dataset that are most similar based on their overall gene expression in all the analyzed genes, and creates a node to join these two samples. It then identifies the sample that is most similar to these two, and connects it with them through another node. The process is repeated until all the samples are organized in a dendrogram, in which the distances reflect the gene expression differences between samples.

\subsection{Cloning of PCR products into vectors}

TA cloning is a technique to clone a PCR product into a vector by utilizing the ability of adenine-overhangs on the PCR product to hybridize to thymine overhangs of the vector ${ }^{208}$. The PCR product is created through use of a Taq polymerase, which adds an adenine residue to each 3' end of the product with a high probability. The vector is linearized and tagged with thymine residues in the 3' ends. In this work, the vector was bought ready-made with thymine-overhangs and contains a gene for ampicillin resistance. It also contains a LacZ gene which encodes the enzyme $\beta$-galactosidase, but this gene is spanning over the insert site and is therefore disrupted when a PCR product is inserted into the vector. After insertion of the PCR products, the vectors were transformed into Escherichia coli cells. The cells were spread on agar plates containing ampicillin and X-gal, which is a lactose analog that gives rise to a blue pigment when cleaved by $\beta$-galactosidase. E. coli colonies containing inserts could thus be selected based on their lack of blue color. The insert was amplified by a new PCR and sequenced with Sanger sequencing. In Paper I, this technique was used in order to obtain separate cDNA sequences from the mutated and the normal allele in a sample with a cryptic NF1 mutation, which otherwise gave rise to a mixed sequence that was difficult to interpret. In Paper II and Paper III, the method was used to investigate whether two EPAS1 mutations in the same sample occurred in cis (in the same copy of the gene, i.e. on the same chromosome of a homologous pair) or in trans (on different chromosomes).

\subsection{Immunohistochemistry}

Immunohistochemistry is a well established method that utilizes antibodies to detect proteins or other antigens in tissue sections ${ }^{209,210}$. The method was used in Paper I to detect SDHB protein expression. The formalin-fixed paraffin-embedded tissue sections which had been mounted on glass slides were first deparaffinized and rehydrated in xylene and a graded 
ethanol series. They were then boiled in citrate buffer to uncover the antigen epitopes. After incubation with the primary antibody, a biotinylated secondary antibody was added. This was then visualized using the avidin/biotinylated complex method ${ }^{210}$.

\subsection{Laser-capture microdissection}

Laser-capture microdissection can be used to isolate subpopulations of cells from a tissue section during visualization in a microscope. It was used in Paper I in order to separate normal cells from tumor cells (to allow separate genetic analysis) in a tumor sample for which no corresponding blood sample was available. The basis of the technique is to place a thermolabile polymer film over the tissue section and to melt the polymer with a laser pulse in the regions where the desired cells can be seen in the microscope ${ }^{211}$. When the polymer is locally melted, it comes into direct contact with the tissue slide and attaches to the cells in that area. When the polymer is removed, it takes the captured cells with it, and their DNA contents can be released into solution by proteinase $\mathrm{K}$ treatment. 


\section{RESULT SUMMARY AND DISCUSSION}

\subsection{Integrative genomics reveals frequent somatic $N F 1$ mutations in sporadic pheochromocytomas (Paper I)}

In the first study ${ }^{212}$, we investigated the known familial pheochromocytoma genes in 42 sporadic pheochromocytomas. This was performed by studying copy number alterations, gene expression, promoter methylation and somatic mutations. First, the tumors were investigated for germline and somatic mutations in any of the genes RET, $V H L, S D H B, S D H D$, and $M A X$ by Sanger sequencing. No germline mutations were observed, but one tumor $(2.4 \%)$ had a somatic RET mutation (c.1893_1898delCGAGCT) not present in the blood DNA of the patient. For 21 cases where paraffin-embedded tissue sections were available, mutations in any of the more rarely involved $S D H x$ genes ( $S D H A, S D H C$ and $S D H A F 2)$ could be excluded by positive immunohistochemical SDHB staining, which has previously been demonstrated to indicate absence of mutations in any of the $S D H x$ genes $^{56-58}$.

To study genome-wide DNA copy number in the tumors, we used high-density DNA microarrays. We detected a number of large chromosomal alterations such as deletion of $1 \mathrm{p}$, $3 q, 11 p$ and $22 q$ with similar frequencies as has previously been reported ${ }^{113,114}$ (Figure 4 and Figure 5).

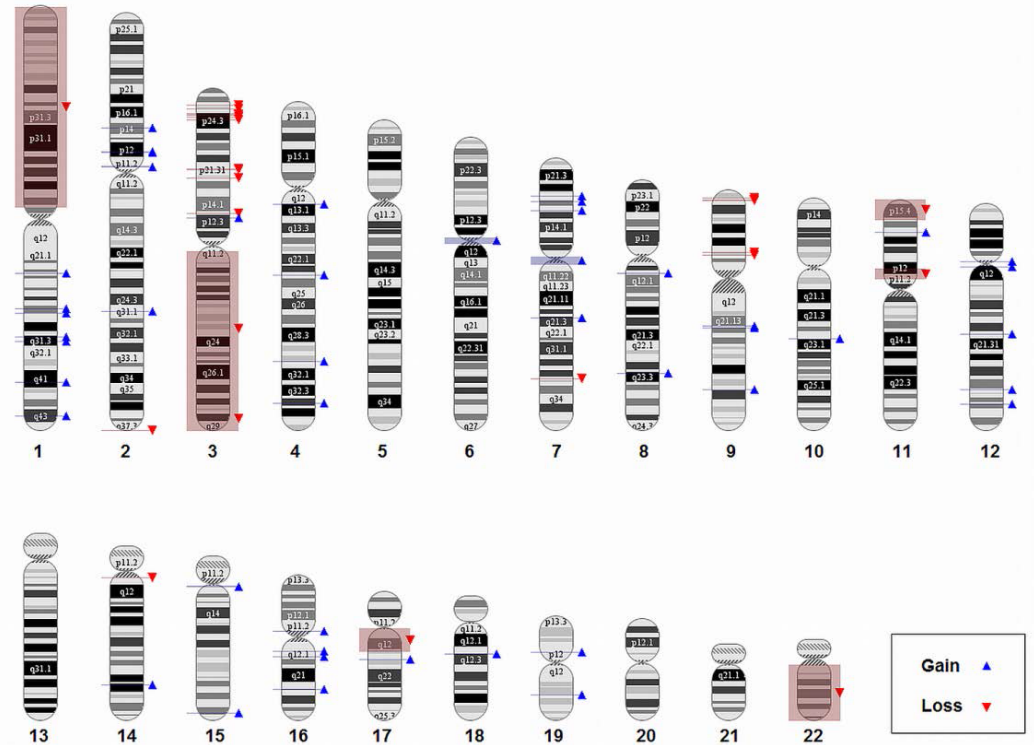

Figure 4. Example of copy number alterations in a sporadic pheochromocytoma. Loss of genetic material is shown as light red segments with red arrows, and gains are shown in blue. Only alterations that were covered by at least ten adjacent markers are reported. The visualization was exported from the Affymetrix Genotyping Console software. 


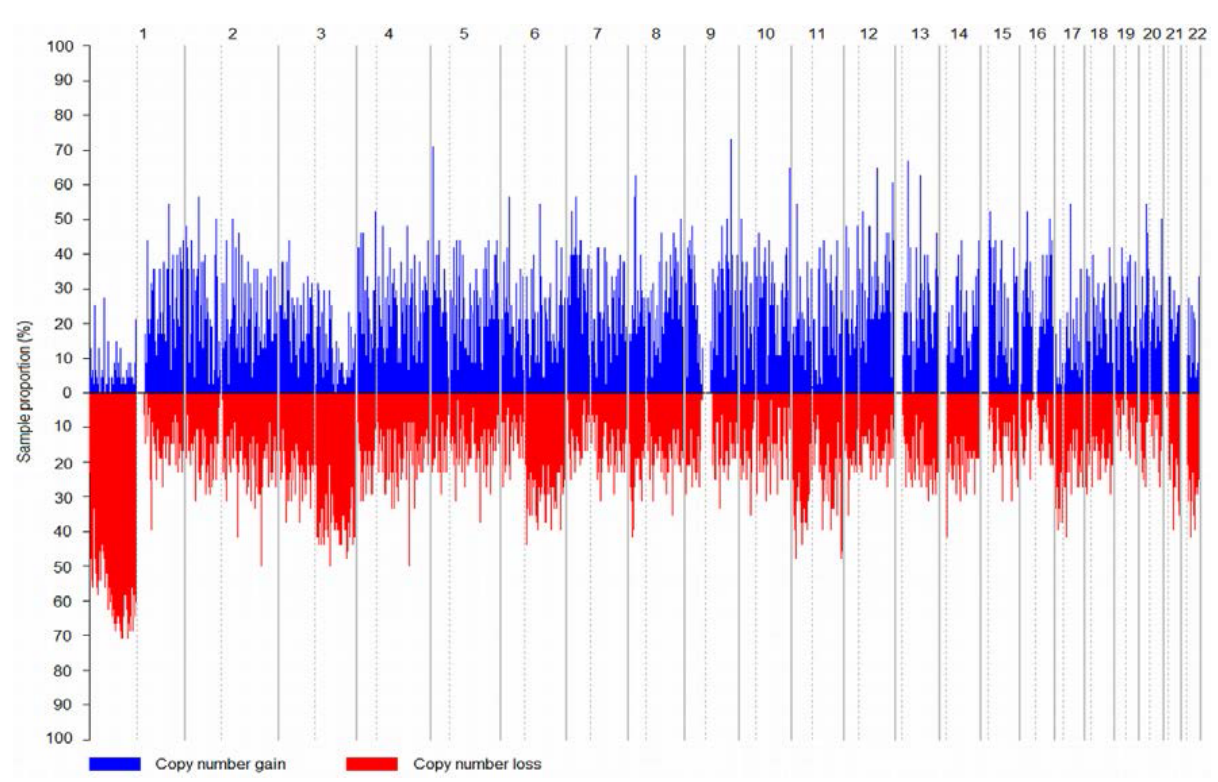

Figure 5. Summary of copy number alterations in the included sporadic tumors. Chromosomes are shown on the x-axis and the proportion of samples with gain or loss on the $y$-axis. Deletion of chromosome arm $1 p$ was the most frequent large alteration in the cohort. The summary was created using the dChip software with default settings and smoothing of the copy number over 10 marker-windows ${ }^{213}$. To allow for some normal tissue in the tumor samples, gain was here defined as a copy number $\geq 2.8$ and loss as a copy number $\leq 1.2$.

When investigating the copy number state of the genes that have so far been associated with susceptibility to pheochromocytoma and/or paraganglioma, RET, VHL, NF1, SDHA, SDHB, $S D H C, S D H D, S D H A F 2, K I F 1 B \beta, T M E M 127$ and $M A X$, we found that 35 of the 42 samples $(83 \%)$ had an altered copy number in at least one of the genes. It is unknown how many of these events that are actual drivers in the tumor development. Many are likely to be a consequence of larger events, for example both $S D H B$ and $K I F I B \beta$ are located on $1 \mathrm{p}$ which is frequently deleted. However, there were also several focal deletions covering only about 100 $500 \mathrm{kbp}$ which could suggest that the familial gene might have been the target of the event. A notable observation was that eleven of the 42 samples showed loss of one copy at a part of chromosome 17q. The minimal region of overlap between the alterations included 17q11.2, where the NF1 gene is located (Figure 6).

Next, we used reverse transcription quantitative real time PCR to compare the mRNA expression between tumor samples with and without an altered copy number. For the genes $N F 1, S D H D, S D H A F 2, K I F 1 B \beta$ and $V H L$ we found a significantly lower gene expression in samples with loss of one copy compared to those with normal copy number, which was particularly apparent for the $N F 1$ gene $(\mathrm{p}<0.00001)$. A similar correlation between loss and gene expression has been observed for SDHD and SDHAF2 in VHL-associated pheochromocytomas (which often have loss of chromosome $11^{214}$ ), but the pathological significance of this phenomenon is unknown ${ }^{215}$. 


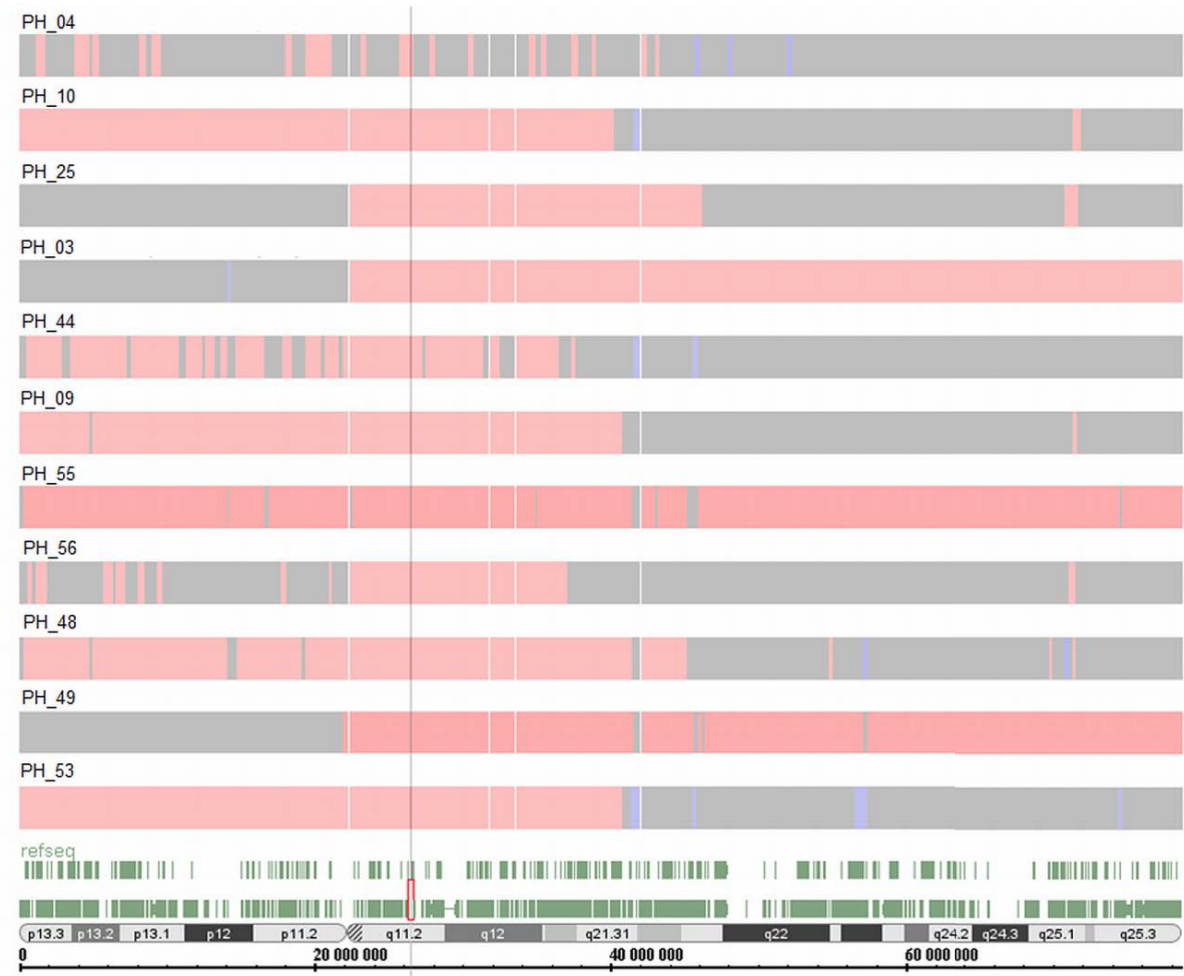

Figure 6. Deletion of a common region on chromosome $17 q$ in eleven tumors. Chromosome 17 of each tumor is represented by horizontal bars. Losses of one copy are here represented in light red and gains of one copy are represented in light blue. Genes, cytobands and base pair positions are shown in tracks below the tumor samples. The position of the NF1 gene is indicated by the vertical line at 17q11.2. The visualization was exported from the Affymetrix Genotyping Console software.

We also analyzed the promoter region of the susceptibility genes for hypermethylation, which could represent another mechanism of gene inactivation, but we did not detect methylation in any of the genes. This is in agreement with previous studies that analyzed the $S D H B, S D H D$ and $V H L$ genes without finding promoter methylation ${ }^{146,216}$. However, interestingly, a later study reported $V H L$ promoter methylation in pheochromocytomas and paragangliomas (but not in EGLN1, MAX, MEN1, NF1, RET, SDHB, SDHC, SDHD, SDHAF2, or TMEM127) ${ }^{217}$. The discrepancy with our data regarding $V H L$ is most likely due to differences in the methodology: the new study detected methylation with a quantitative pyrosequencing assay that covered $\mathrm{CpG}$ sites upstream of the sites covered by us and the previous studies, and could therefore detect methylation that had previously been missed. For future studies, it may be interesting to apply the new method to the samples of our and other cohorts in order to relate epigenetic silencing of $V H L$ with already obtained copy number and gene expression data.

Despite the association between the NF1 syndrome and familial pheochromocytomas, the NF1 gene has previously not gained much attention in the research of sporadic 
pheochromocytoma. One of the reasons may be that the prevalence of pheochromocytomas in patients with the NF1 syndrome is so low ${ }^{218}$. Also, the NF1 gene is very large and is rarely sequenced even in NF1 patients, since they can generally be diagnosed based on clear symptoms that occur in early childhood. However, the frequent loss of one NF1 copy, in combination with very low NF1 mRNA levels in those samples, prompted us to search for somatic NF1 mutations inactivating the remaining copy of the gene. By sequencing the NF1 mRNA, converted into cDNA, we detected truncating somatic mutations in ten of the eleven samples with copy number loss, but not in any of the samples without loss, which is in agreement with the two-hit principle of tumor suppressor genes ${ }^{5,6}$. The mutations were also confirmed in genomic DNA. In two cases, genomic DNA analysis would suggest point mutations to be missense, but the cDNA evidence showed that they in fact give rise to de novo splice sites that result in partial exon skipping. Bioinformatics analysis ${ }^{219}$ also suggested that the novel splice sites are stronger than the corresponding natural splice sites. In a third cryptic case, a part of intron 13 was present between exons 13 and 14 in the cDNA. Bioinformatics analysis suggested that this might be caused by a point mutation more than 1000 bases into intron 13 that gives rise to a strong de novo 5' splice site. Together with an existing upstream cryptic 3' splice site, it results in the inclusion of a 54 bases long cryptic exon that contains a stop codon (visualized in the supplement of the paper). The predicted mutation in intron 13 could be confirmed with genomic DNA analysis.

Tumors with somatic NF1 mutations were associated with higher plasma levels of metanephrine $(p=0.0025)$ and normetanephrine $(p=0.0050)$. The higher levels of metanephrine (indicating epinephrine production) are in agreement with data from familial tumors, where epinephrine levels are increased in patients with NF1- and MEN2-related pheochromocytomas compared to other patients ${ }^{136}$. However, previous studies have not shown any differences in normetanephrine levels. In this study, there was a tendency of NF1mutated tumors to be larger than those without NF1 mutations. It can therefore not be excluded that the increased hormone levels in part may be explained by the larger volumes of secreting tumor cells.

In conclusion, the results of this paper suggest that the genes involved in hereditary pheochromocytoma may be important players also in the sporadic disease, as many of them show copy number loss in combination with a low gene expression. Specifically, somatic NF1 mutations were revealed to be frequent in sporadic pheochromocytomas, with a frequency of $23.8 \%$ in this study. Somatic NF1 mutations are also likely to be responsible for some of the NF1/RET-associated gene expression patterns that have been observed in a subset of sporadic pheochromocytomas $^{118,138,139,141}$.

An independent study, which was published in the same journal issue, indeed confirmed the results of this paper by reporting somatic NF1 mutations in $21.8 \%$ of sporadic pheochromocytomas, also with loss of heterozygosity $(\mathrm{LOH})$ in the majority of the mutated tumors $^{220}$. Somatic NF1 mutations have also been reported in other sporadic neoplasms including glioblastomas ${ }^{181}$, malignant peripheral nerve sheath tumors ${ }^{221}$, acute myelogenous leukemias $^{222}$, neuroblastomas ${ }^{223}$, lung adenocarcinomas ${ }^{224}$ and ovarian carcinomas ${ }^{225}$, indicating that neurofibromin can be a significant player in both neural- and non-neuralderived cancers. 


\subsection{Frequent EPAS1/HIF2 $\alpha$ exons 9 and 12 mutations in non-familial pheochromocytoma (Paper II)}

In the second study ${ }^{134}$, we investigated the new susceptibility gene EPAS1, which encodes HIF- $2 \alpha$. The aim of this study was to further characterize the importance of EPAS1 mutations in sporadic pheochromocytomas, as only a few cases with a single sporadic tumor and no polycythemia had so far been reported ${ }^{120}$. We sequenced exon 9 and exon 12 of EPAS1, which contain the two hydroxylation sites that are involved in HIF- $2 \alpha$ degradation, in a cohort of 42 sporadic pheochromocytomas not associated with polycythemia (the same cohort as in Paper I). As one mutation of unknown significance has been reported in exon 2, close to the DNA binding domain of the protein ${ }^{84}$, we also added this exon to the analysis.

We found six missense mutations/variants in five tumors, three in exon 9 and three in exon 12. Cloning showed that the two mutations which occurred in the same tumor (one close to each of the two hydroxylation sites) were in cis, i.e. on the same chromosome. This might suggest that a combined inactivation of both hydroxylation sites could lead to an even higher HIF- $2 \alpha$ stability than one mutation would cause alone, as previous results have suggested for the HIF-1 $\alpha$ protein $^{226}$. When examining previously obtained copy number data, we also noticed that one tumor with an EPAS1 mutation had copy number gain of the EPAS1 locus. The importance of the event is unknown, but a combination of activating mutations and copy number gain has previously been reported for $E P A S 1^{120}$, as well as for other protooncogenes $^{227}$. The three mutations in exon 12 occur in or adjacent to the primary hydroxylation site and are likely to be pathogenic, as mutations in this site have previously been reported in pheochromocytomas and paragangliomas and have been shown to affect the degradation of HIF- $2 \alpha^{80,84,228}$. The pathogenic importance of the three variants in exon 9 is more uncertain and will require further studies, as only one of them has previously been reported in a patient with paraganglioma and polycythemia ${ }^{83}$. The mother of that patient carried the same variant but did not have any symptoms, although polycythemia could not be excluded based on available blood tests. The variant, Phe374Tyr, was demonstrated to have functional importance as it decreased VHL protein binding and ubiquitination and increased the stability of HIF- $2 \alpha^{83}$. On the other hand, it has been reported as a rare polymorphism (rs150797491) and has a total allele frequency of 0.00092 in the populations summarized in the Ensembl database. It was also predicted as probably benign by the PolyPhen software ${ }^{229}$. Possibly it predisposes carriers to polycythemia and paragangliomas but with an incomplete penetrance, which might also be the case for the other two exon 9 variants.

To further investigate the effect of the identified EPAS1 mutations, we performed genomewide microarray gene expression analysis. First, we studied the expression of EPAS1 itself and some of its known target genes, and found that both EPAS1 $(\mathrm{p}=0.0031)$ and VEGFA $(\mathrm{p}=0.0039)$ were significantly upregulated in tumors with EPAS1 mutations. The reason for the upregulation of EPAS1 is not clear, as the mutations are thought to act on the protein level, but a possible explanation could be that cells with a high EPAS1 expression to begin with are more vulnerable to tumor formation driven by EPAS1 mutations than other cells. Upregulation of EPAS1 in mutated tumors has also been observed by others ${ }^{120}$. VEGFA upregulation is in agreement with increased HIF-2 $\alpha$ signaling $^{78}$. We also studied the PNMT gene and found that it had a very low expression in EPAS1-mutated tumors compared to those 
without EPAS1 mutations $(\mathrm{p}<0.0001)$. The low PNMT expression is in agreement with a mainly noradrenergic hormone profile in the patients, and is consistent with the low PNMT expression and epinephrine production found in VHL- and SDH-related tumors ${ }^{118,138}$.

To examine how the EPAS1-mutated tumors would cluster compared to the previously known clusters $^{118}$, we performed hierarchical clustering and found that all the tumors with EPAS1 mutations clustered close to the VHL- and SDH-related tumors in cluster 1 . This strengthens the functional importance of the detected mutations, but it cannot be excluded that some of the tumors may have cluster 1 properties that are caused by other factors than EPAS1 alterations.

Next, we performed a genome-wide test for differential expression and found 22 genes that were significantly and more than 2-fold differentially expressed between EPAS1-mutated tumors and tumors without EPAS1 mutations. Among those that were upregulated in EPAS1 cases were several genes that are involved in angiogenesis (KDR/VEGFR, ANGPT2) and cell metabolism (COX4I2, NOX4, FOLH1, FOLH1B, COX17). COX4I2, which was the most significantly upregulated gene, has previously been reported to be strongly upregulated in VHL/SDH-related pheochromocytomas ${ }^{140}$. Another upregulated gene, GNA14, was recently observed to be significantly upregulated in EPAS1-mutated tumors ${ }^{120}$. Among the most downregulated genes was PNMT, but also NCAM2 (a neural cell adhesion molecule, previously found upregulated in cluster 2 tumors ${ }^{118}$ ) and HCN1 (a cation channel contributing to neuron currents). The downregulation of PNMT and genes with neural function supports the previous observation that cluster 1 tumors have less neuroendocrine differentiation than cluster 2 tumors $^{118,230}$.

Previous findings of EPAS1 mutations in different tumors from the same patient, but not in germline DNA, indicate that somatic EPAS1 mutations may occur in a cell during embryogenesis and predispose the affected tissues to tumor formation ${ }^{80}$. Possibly the time point of the mutation (early in embryogenesis or later in life) may explain the variety of observed phenotypes which include polycythemia without tumors ${ }^{231}$, polycythemia in combination with single or multiple pheochromocytomas/paragangliomas and sometimes multiple somatostatinomas ${ }^{80,85,228,232}$, as well as single or multiple pheochromocytomas/ paragangliomas without polycythemia ${ }^{84,120}$. In addition to somatic mutations, one case with an inherited mutation has been described before ${ }^{83}$. The mutation was identical to one mutation discovered in this study, but unlike the previous case, our case did not have polycythemia. The penetrance of pheochromocytoma/paraganglioma for germline EPAS1 mutations is still unknown and will require further family studies.

In conclusion, this study showed that both germline and somatic EPAS1 mutations, in both exon 9 and exon 12, occur in sporadic pheochromocytomas. The pathogenic significance of the germline exon 9 mutations remains unclear, but all the tumors with EPAS1 mutations clustered together with VHL- and SDH-related tumors based on gene expression data. The EPAS1-mutated tumors also had a high gene expression of EPAS1 and its target gene VEGFA, whereas they had very low expression of $P N M T$, which is in agreement with their cluster 1 identity. A summary of detected EPAS1 mutations together with those detected in Paper III is given in Figure 7. 


\subsection{Rare germline mutations identified by targeted next-generation sequencing of susceptibility genes in pheochromocytoma and paraganglioma (Paper III)}

In the third study ${ }^{135}$, we designed a next-generation sequencing approach in order to comprehensively study all the known susceptibility genes in a large cohort of pheochromocytomas and paragangliomas, and also to evaluate the usefulness of the method for genetic testing. The assay was used for mutation analysis in 86 unselected pheochromocytoma and paraganglioma tumor samples without overlap to the cohort used in Paper I and Paper II.

As traditional Sanger sequencing of multiple genes is both expensive and time-consuming, we designed a targeted gene panel for next-generation sequencing of the genes so far known to be associated with pheochromocytoma or paraganglioma: EGLN1, KIF1B $\beta, M A X, M E N 1$, NF1, RET, SDHA, SDHB, SDHC, SDHD, SDHAF2, TMEM127 and VHL. For the genes EGLN1 and $K I F 1 B \beta$, mutations have so far only been described in a few isolated cases, and their importance in pheochromocytoma and paraganglioma is still unknown ${ }^{90,91,93,94}$. Regarding the MEN1 gene, pheochromocytoma has been reported in a few patients with multiple endocrine neoplasia type 1 (MEN1) ${ }^{31,105}$, and a MEN1 patient with PGL was recently reported for the first time ${ }^{233}$, but MEN1 mutations have so far not been identified in sporadic tumors $^{234}$. Comprehensive investigations of all the genes in the same cohort are lacking, so the incidence of mutations in more than one of the genes in the same tumor it is also unknown. The EPAS1 gene was not yet known to be involved when we finalized the design of the panel, and it was therefore instead sequenced with Sanger sequencing in the included samples.

The cohort consisted of unselected cases (both sporadic and familial) of pheochromocytoma and paraganglioma surgically removed in Stockholm. When using the new sequencing approach on 18 cases with previously known syndromes and/or germline mutations, we found a mutation in the expected gene in all cases, indicating a high sensitivity of the method. In addition, one NF1 case also had a somatic mutation in $K I F 1 B \beta$ which was predicted to be pathogenic by two bioinformatic algorithms ${ }^{229,235}$. Among 68 apparently sporadic tumors we found 32 protein-altering mutations. All mutations could be verified with Sanger sequencing, indicating a high specificity of the method. The mutation status was also checked in normal DNA in all cases where it was possible.

The most frequently altered gene in the cohort was NF1, which, in agreement with our results in Paper I and those of another study ${ }^{220}$, harbored somatic mutations in $22.4 \%$ of the sporadic pheochromocytomas. Another frequently altered gene was EPAS1, in which mutations were identified in a similar total frequency as in Paper II (7.4\% of all sporadic tumors). In the present cohort, EPAS1 mutations were however ten times more prevalent in the paragangliomas (3/10 tumors, 30\%) than in the pheochromocytomas (2/58 tumors, $3.4 \%)$. In agreement with previous findings ${ }^{80,84,120,232}$, two of the patients with EPAS1 mutations had polycythemia. Interestingly, one paraganglioma had two somatic EPAS1 mutations in cis. Just like the case in Paper II, one mutation occurred in exon 9, only two residues from the hydroxylation site Pro405, and the other in exon 12, one residue from the hydroxylation site 
Pro531. However, in this case both mutations were somatic as opposed to the previous case where the exon 9 mutation was germline. A summary of the EPAS1 mutations from both Paper II and Paper III is given in Figure 7.
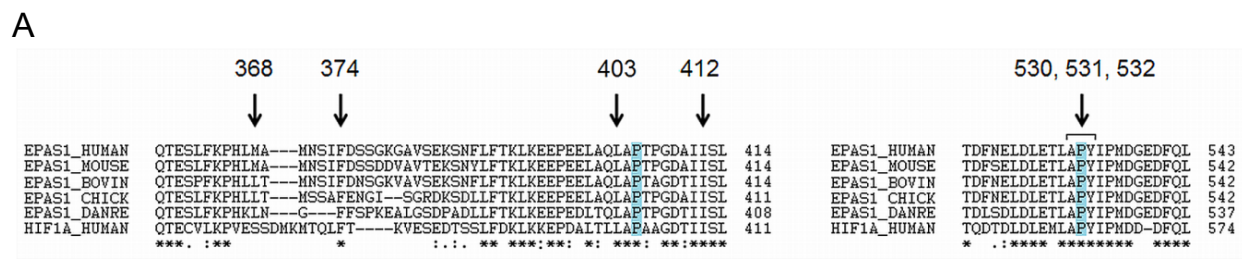

B

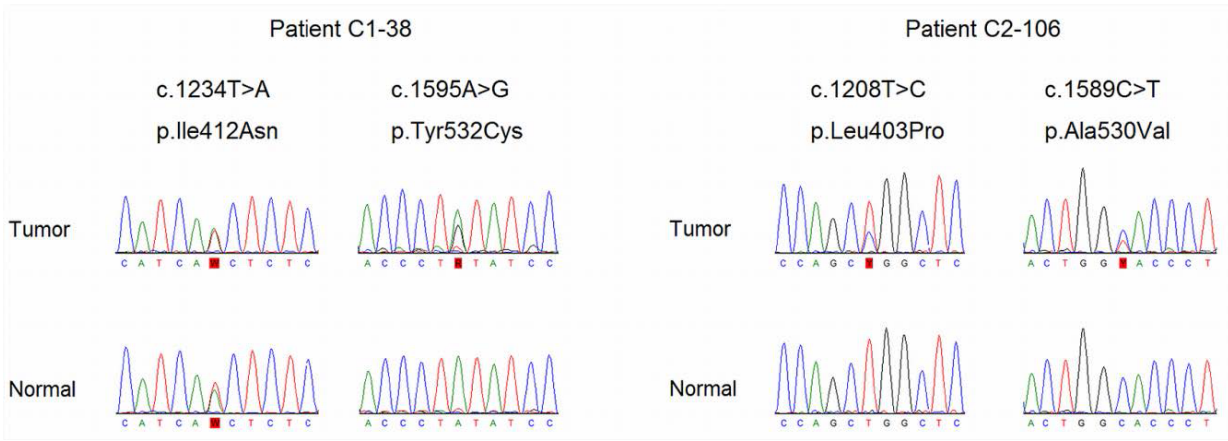

Figure 7. EPAS1 (HIF-2 $\alpha$ ) mutations in pheochromocytomas and paragangliomas.

A) Summary of the location of EPAS1 mutations detected in Paper II and Paper III. In total, 12 mutations were detected in ten out of 110 investigated sporadic tumors. Four of the mutations occurred in exon 9, whereas the remaining mutations affected residues 530, 531 or 532 in exon 12. A multiple sequence alignment of the UniProt protein sequence from different species was performed with the Clustal $\Omega$ tool ${ }^{236}$ to investigate evolutionary conservation of

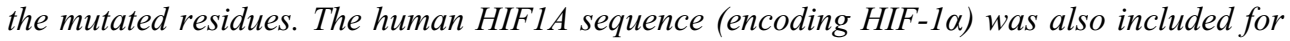
comparison. Prolyl hydroxylation occurs at Pro405 and Pro531 in human HIF-2 $\alpha$, indicated with blue color. Symbols: [*], identical residues; [:], conserved substitutions; [.], semiconserved substitutions. B) Sanger sequencing data for cases with double EPAS1 mutations. The sequences from tumor and normal DNA show that one case had one germline and one somatic mutation, whereas the other case had two somatic mutations. In both cases, the two mutations were shown by cloning to occur in cis, i.e. on the same chromosome.

Mutations in $M A X, T M E M 127, R E T, V H L$ and $S D H B$ were found in expected frequencies ${ }^{31,67,}$ 76, 118, but no mutations were detected in $S D H C, S D H D$ or $S D H A F 2$. Germline SDHA mutations have so far only been reported in a few studies. They have mainly been associated with paragangliomas ${ }^{53,58}$ and have only rarely been reported in pheochromocytomas ${ }^{58}$, but here we report two mutations in pheochromocytoma patients. One pheochromocytoma patient had a germline EGLN1 variant of unknown significance, as two different prediction algorithms gave inconclusive results regarding its pathogenicity. No mutations were found in the MEN1 gene, suggesting that it is of no or minor importance in sporadic pheochromo- 
cytoma and paraganglioma. On the other hand, a very recent study reported germline MEN1 mutations in two patients with the combination of non-familial pheochromocytoma and pituitary adenoma ${ }^{237}$. In this study, both pheochromocytomas showed LOH in the MEN1 gene, and the role of MEN1 in pheochromocytoma thus still warrants further studies.

One germline $K I F 1 B \beta$ mutation was identified in a patient with apparently sporadic pheochromocytoma. The mutation was predicted as pathogenic and affects a highly conserved region of the protein close to the site of a mutation previously identified in neuroblastoma ${ }^{72}$, which has been shown to be of functional importance ${ }^{238}$. Even though it was only detected in one case, the frequency in apparently sporadic pheochromocytomas $(1.7 \%)$ is similar to the previously reported frequencies of germline $M A X$ and TMEM127 mutations ${ }^{67,76}$. Thus, $K I F 1 B \beta$ may be an equally important tumor suppressor gene that warrants further studies. The somatic KIF1B $\beta$ mutation that was identified in a case of NF1-related pheochromocytoma may further support the importance of the gene, but could also be a passenger event. For both $K I F 1 B \beta$ and the other genes that are infrequently involved, further investigations in additional patient cohorts will be required to determine the penetrance of the disease and the association with other clinically relevant parameters.

In total, $26.7 \%$ of all cases in the cohort carried germline mutations. Among the sporadic cases, $7 \%$ carried germline mutations even though no family history or other signs of hereditary disease were known based on the medical records of the patients. The results also showed that the familial susceptibility genes are involved, either by germline or somatic mutation, in $41 \%$ of the sporadic tumors. It could be noted that a fraction of the cases had mutations in more than one associated gene. For example, one tumor had a splice-site mutation in NF1 in combination with a nonsense mutation in MAX. A summary of all mutations detected in sporadic pheochromocytomas and paragangliomas from Paper I, Paper II and Paper III is given in Figure 8.

The targeted next-generation sequencing approach used in this study proved to be considerably faster and less expensive than Sanger sequencing for comprehensive mutation analysis in pheochromocytoma and paraganglioma. The usefulness in clinical care was confirmed when the method was used for genetic testing in a young patient with a large paraganglioma, who was revealed to carry a germline truncating SDHA mutation ${ }^{239}$. Such patients may be important to identify to allow early tumor detection, correct management and also to identify relatives that may be at risk ${ }^{23,240}$, but further research is still required to determine the risks associated with these rarely involved susceptibility genes. The list of associated genes has been growing fast during the recent years and targeted panels such as the one used here will probably need frequent updating. In addition, custom-designed probes generally need to be ordered in large quantities (for 96 samples with the assay in this study), and whole-exome sequencing may thus be a better alternative if only a few samples are to be analyzed. On the other hand, exome sequencing may give rise to more ethical concerns regarding patient integrity and incidental findings. In clinical genetic testing there is always a risk of finding variants of uncertain significance, i.e. variants for which the pathogenic importance is unknown and cannot easily be tested ${ }^{241}$. Although traditional Sanger sequencing of one gene at a time, based on a decision algorithm for the order of testing ${ }^{137}$, can also suffer from such problems, the risk becomes higher with next-generation sequencing methods 
because of the large amounts of genetic data that are generated. Erroneous interpretation of variants may lead to an incorrect genetic diagnosis which could have serious consequences for the patients and their relatives ${ }^{242}$. Thus, although next-generation sequencing methods offer fast and cost-efficient screening of susceptibility genes, the results, especially missense variants, will require careful interpretation by experienced geneticists before they are considered in the management of the disease.

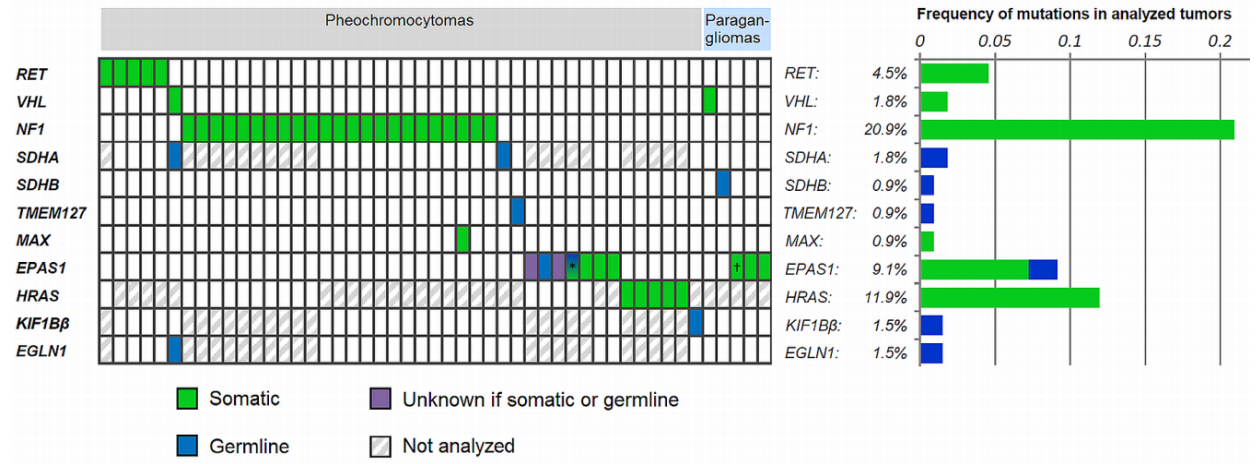

Figure 8. Summary of mutations detected in 110 cases of sporadic pheochromocytoma and paraganglioma from Scandinavia, with total mutation frequencies in all analyzed cases. The data was collected in Paper I, Paper II and Paper III, except for the data from the HRAS gene, which was analyzed in the Paper I/Paper II cohort after publication. Cases in which no mutations were detected (61 cases) are not shown. SDHA, KIF1B $\beta$ and EGLN1 were only analyzed in the larger cohort of Paper III where next-generation sequencing was used. The star (*) indicates a sample with two EPAS1 mutations, one somatic and one germline. The cross ( $\dagger$ indicates a sample with two somatic EPAS1 mutations. Further details about the samples and analyses are given in the respective papers.

In conclusion, the results of the study indicate that a large proportion of sporadic pheochromocytomas and paragangliomas carry mutations in the known susceptibility genes, including more rarely investigated genes like $K I F 1 B \beta$. However, further studies will be required to examine the functional and clinical relevance of some of these mutations. The targeted next-generation sequencing technique proved to be useful for the genetic testing and might be considered for clinical use. 


\subsection{Activating FGFR1 mutations in sporadic pheochromocytoma (Paper IV)}

After the first three papers of the thesis, together with the parallel studies by others, it could be concluded that around $50 \%$ of sporadic pheochromocytomas are still lacking a known causative genetic event. In the fourth study, we attempted to search for some of these unknown alterations by next-generation sequencing of the whole exome in tumors and corresponding blood samples from 16 patients with sporadic pheochromocytoma from Linköping, Sweden. Six of these were cases from the Paper I and Paper II cohort that had tested negative for mutations in all the so far investigated genes (including HRAS, which was now investigated (Figure 8), and KRAS, NRAS, BRAF and the TERT promoter, in which no mutations were detected). The remaining ten cases for exome analysis were recently surgically removed and had unknown mutation status, but did not have any family history or syndromic features.

The analysis of somatic mutations resulted in the detection of a median of 33 non-silent somatic mutations (point mutations or indels) per tumor. In comparison, a large exome sequencing study across 27 different cancer types previously revealed a median of 44 nonsilent somatic mutations per tumor sample, ranging from about one event per sample in paediatric cancers to thousands in melanomas and lung tumors from patients with extensive exposure to known carcinogens ${ }^{243}$. Most of the affected genes in the pheochromocytomas were unique to one sample, suggesting that there is a large heterogeneity of somatic events in these tumors. Many of these are likely to be passenger events, and more studies in larger cohorts will be required to find which alterations are true but infrequent drivers in the tumorigenesis. Nevertheless, some genes were found to be recurrently altered. For example, the NF1 gene harbored somatic mutations in three of the ten samples where it had not previously been tested, in agreement with our previous reports.

Another recurrently altered gene was FGFR1, encoding fibroblast growth factor receptor 1, which harbored somatic mutations in two different samples. The two mutations, Asn546Lys and Lys656Glu, affect the same two hotspot positions in which recurrent oncogenic mutations were most recently discovered in the paediatric brain tumor form pilocytic astrocytoma ${ }^{182}$. The same residues have also occasionally been observed mutated in glioblastomas ${ }^{181}$, and can be confirmed to be the most frequently mutated FGFR1 sites in the Catalogue of Somatic Mutations in Cancer database ${ }^{244}$. The two mutations affect the kinase domain (Figure 9) and have been shown to promote cell proliferation ${ }^{245}$. Asn546Lys has also been shown to alter the autophosphorylation of FGFR $1^{246}$. Our findings are in agreement with evidence showing that overexpression of FGFR1 results in MAPK and AKT activation in the rat pheochromocytoma cell line $\mathrm{PC} 12^{247}$.

Next, we sequenced the FGFR1 gene in 64 additional sporadic tumors (the rest of the cohort from Linköping and Bergen plus a new cohort from France). This revealed a single additional Asn546Lys mutation, suggesting a total mutation frequency of $3.8 \%$ in sporadic pheochromocytomas. 
To further study the biological consequences of $F G F R 1$ mutations, we performed microarray gene expression analysis and could conclude that $F G F R 1$-mutated tumors clustered in "cluster 2" together with tumors that had mutations in RET, NF1 and HRAS. This was not surprising as activation of FGFRs is known to activate the RAS/RAF/MAPK and the PI3K/AKT pathways ${ }^{175}$. There were no specific genes that differed significantly in expression between tumors with and without FGFRI mutations after correction for multiple testing. A possible explanation could be that FGFRI-mutated tumors have gene expression profiles that are very similar to profiles of other tumors in cluster 2, and that the number of FGFR1-related tumors was too small to detect minor differences in the expression patterns. Copy number data, which was available for two of the mutated samples, showed that one of the tumors also had a gain (three copies) of the FGFR1 locus. No gains were observed for 19 pheochromocytomas without FGFRI mutations.

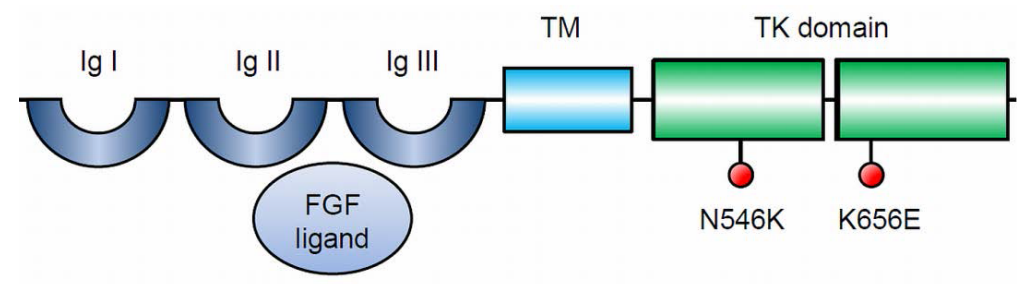

Figure 9. Schematic overview of the domain structure of the FGFR1 protein and the position of mutations identified in pheochromocytomas. FGFRI consists of three extracellular immunoglobulin domains (Ig), one transmembrane helix (TM) and one intracellular split tyrosine kinase domain $(T K)^{175,182}$. The second and third immunoglobulin domains form the ligand-binding pocket. The identified activating mutations (Asn546Lys and Lys656Glu) affect the tyrosine kinase domain and are proposed to lead to constitutive FGFRI activation.

We also used the exome data to screen for germline and somatic mutations in all the genes known to be associated with pheochromocytoma or paraganglioma. The analysis revealed one truncating germline $S D H B$ mutation. Except for the recurrent somatic NF1 mutations, we detected one somatic mutation each in VHL, RET, MAX and HRAS, in agreement with previous reports ${ }^{76,118,121,123,135}$. The $M A X$ mutation was truncating and occurred in one of the tumors that also had a somatic FGFRl mutation, suggesting that a combination of the two events may confer a selective advantage to the tumor cells. The other two tumors with FGFRI mutations did not have any mutations in any of the known pheochromocytoma or paraganglioma associated genes.

In conclusion, we report the FGFR1 proto-oncogene as a novel target of somatic activating mutations in sporadic pheochromocytomas. FGFR1 mutations are likely to be driver events in a small subset of cluster 2 tumors, which are characterized by RAS/RAF/MAPK and $\mathrm{PI} 3 \mathrm{~K} / \mathrm{AKT}$ activation. They may also be present in combination with other driver events, as one of the FGFR1-mutated tumors analyzed here also harbored a somatic MAX mutation. Future studies in larger cohorts will be valuable in order to accurately estimate the frequency of FGFRl alterations in pheochromocytomas and paragangliomas. 


\section{CONCLUDING REMARKS}

This thesis work has aimed to further characterize the genetic and genomic background of sporadic pheochromocytomas and paragangliomas. Several of the genes known from familial pheochromocytoma and paraganglioma were shown to be affected by somatic alterations, which were in turn associated with changes in gene expression. Notably, somatic mutations in the NF1 gene were discovered in $22-24 \%$ of sporadic pheochromocytomas, the majority of which were truncating and associated with loss of the normal allele as well as a reduced NF1 expression. The high frequency was somewhat surprising as the other known susceptibility genes only harbor somatic mutations in a few percent of the cases ${ }^{29,115-118}$, and patients with NF1 syndrome only rarely develop pheochromocytoma ${ }^{218}$. We also built on the findings by others and showed frequent EPAS1 mutations in sporadic pheochromocytomas and paragangliomas that were associated with a hypoxia-related gene expression pattern. For the first time we also reported double EPAS1 mutations, which affected one each of the two HIF$2 \alpha$ hydroxylation sites, in two different cases.

A comprehensive next-generation sequencing mutation analysis of known pheochromocytoma and paraganglioma genes showed that germline mutations were present in about $27 \%$ of all tumors and in $7 \%$ of the apparently sporadic tumors. Knowledge of the genetic background can be of importance in order to facilitate early detection and correct treatment of pheochromocytomas, paragangliomas and potential co-occurring cancers, and also to identify relatives that might be at risk. However, further research will be required to determine the risks associated with the more rarely involved susceptibility genes. For example, we identified a germline mutation in $K I F 1 B \beta$. Mutations in this gene have previously only been reported in a few cases of pheochromocytoma and neuroblastoma ${ }^{93,94}$ and have not been investigated in any large cohorts until now. We could conclude that the targeted next-generation sequencing approach was a fast and cost-efficient method for genetic testing of pheochromocytomas and paragangliomas, but if it should be implemented in clinical practice, great care must be taken before reporting variants of unknown significance.

We also noted that some cases had germline and/or somatic alterations in more than one susceptibility gene, which is in agreement with some previously reported $\operatorname{cases}^{220}$. This suggests that a combination of driver events in these genes may confer a survival advantage to the tumor cells. However, knowledge of any causative genetic event is still unknown for about half of the sporadic tumors, suggesting that additional genes are involved. In an attempt to uncover additional driver alterations in sporadic pheochromocytomas, we performed whole exome sequencing and found recurrent activating mutations in the gene FGFR1, which have previously only been reported in small subsets of brain tumors ${ }^{181,182}$. FGFR1-mutated tumors clustered together with tumors with RET, NF1 and HRAS mutations in our cohort, in agreement with an activation of the RAS/RAF/MAPK and PI3K/AKT signaling cascades.

Together with the excellent studies of others ${ }^{80,118,121,220}$, our results have shown that somatic mutations most likely have a major role in the development of sporadic pheochromocytomas and paragangliomas. During the finishing of this thesis, a new exome-sequencing study of 21 pheochromocytomas was published, which revealed recurrent somatic mutations in the gene 
$A T R X^{248}$. ATRX is thought to be involved in the establishment of transcriptionally silent chromatin and in maintaining telomeres, and mutations have previously been discovered in other cancers, including neuroblastomas, gliomas and pancreatic neuroendocrine tumors ${ }^{249}$. We did not detect any ATRX mutations in the 16 exome-sequenced samples of our study. Two additional new studies reported whole-exome sequencing of 40 and 31 additional pheochromocytomas and paragangliomas, respectively ${ }^{250,251}$. These studies confirmed the involvement of $A T R X$, but also reported other potential novel driver alterations including recurrent mutations in FMR1, TP53, MET and CDKN2A, though neither of the studies identified the FGFR1 gene. However, for many cases a driver mutation could still not be resolved. Many of the drivers that remain to be discovered are likely to be infrequent and difficult to distinguish from passenger events when detected in only one sample. In order to find additional recurrent events, whole-exome sequencing of considerably more cases will probably be required, and RNA sequencing may be valuable to detect potential fusion genes. The next step may be to investigate the non-coding regions of the genome, as was done when mutations in the TERT gene promoter were recently discovered in several tumor forms ${ }^{130-132}$, and later identified in rare cases of pheochromocytoma and paraganglioma ${ }^{129}$. Much work also remains in order to determine the clinical and biological effects of rare germline and somatic alterations and potentially use this information in the development and selection of targeted and personalized treatments. Some antiangiogenic therapies and mTOR inhibitors are already under testing in pheochromocytomas and paragangliomas ${ }^{27}$, and drugs that target FGFRs are being evaluated in other cancers ${ }^{175}$. Further characterization of the genome, transcriptome, epigenome and proteome of pheochromocytomas and paragangliomas may also help to identify novel markers for predicting malignancy, as the currently available indicators, $S D H B$ and potentially $F H$ mutations, occur in less than half of the malignant cases $^{25,87,240}$.

Molecular research on pheochromocytoma and paraganglioma has revealed new links between hypoxia regulation, cell metabolism, epigenetic remodelling and tumorigenesis that has increased our overall understanding of tumor biology and cancer ${ }^{23}$. Hopefully, the characterization of many different tumor forms, from the most benign to the most aggressive, can continue to give us insight into the complexity of human cancers including their development and potential cure. It is hoped that the work presented in this thesis can add a piece to the puzzle of neural crest-derived tumor development, and possibly, together with other scientific studies, contribute to the development of future treatment options. 


\section{ACKNOWLEDGEMENTS}

I would like to express my gratitude to all those who have been involved in making this thesis work possible.

First of all, I want to thank my supervisors Peter Söderkvist and Oliver Gimm for giving me the opportunity to work with this project and to develop as a researcher with your great supervision. I want to thank you for sharing so much of your in-depth knowledge and long experience within molecular genetics and tumor biology, for giving me a lot of good advice but also freedom in the project, and most of all for giving me so much encouragement and inspiration during this journey.

I wish to thank all my colleagues in the Söderkvist lab for creating such a friendly and fun environment to work in and for all the help throughout the years. Annette Molbaek and Åsa Schippert, thank you for teaching me so much in the lab and for always helping out, the lab would be a disastrous place without you. Lena Thunell, thank you for knowing and sharing so much about the university world, and for all help and encouragement regarding teaching and other things. Jonas Ungerbäck and Deepti Verma, thanks for giving me a lot of inspiration during my first years and for interesting scientific discussions. Warm thanks to Ravi Kumar Dutta, Malgorzata Lysiak, Naomi Yamada-Fowler, Mohamed Ali Mosrati, Kerstin Willander, Annika Stjernström, Annika Malmström, Aksa Jawad Ul-Hassan and Vian Osman for being so friendly, helpful and inspiring colleagues, and to all the students who have also been working hard in the lab: Niyaz, Ida, Johan, Cassandra, Nesrine, Miłosz, Adam, Dimitri, Michał, Julia and many others.

Thanks to all the other inhabitants of Cell Biology floor 9 during the years, especially the psoriasis group: Charlotta, Cecilia, Jenny, Anna-Karin and others, for all nice fika moments and interesting discussions. Special thanks to my office-mates Gizeh and Elin for making many days brighter with discussions about life, the universe and everything; to Håkan, who always helps to solve practical problems, and to Linda, who gave me a push into the world of science.

Many thanks to our colleagues in Stockholm, especially Adam Stenman and Catharina Larsson, and also to Roger Wiseman in Wisconsin, for great collaborations. I also want to thank my former colleagues at the National Board of Forensic Medicine, especially Gunilla Holmlund and Andreas Tillmar, for the opportunity to do my master thesis with you, for supervision within genetics and statistics and for continued collaborations. Thanks also to Ivan Shabo and to Aurel Perren and his group for teaching me technical skills.

Many thanks to all patients who have kindly donated samples and medical information to science; none of this research would have been possible without your contribution.

Sist men inte minst vill jag rikta ett varmt tack till min kära familj och mina vänner för ert stöd och för att ni finns där, och ett stort tack till Björn för allt stöd och all kärlek. 


\section{REFERENCES}

1. Yates LR and Campbell PJ (2012). Evolution of the cancer genome. Nat Rev Genet, 13: 795-806.

2. Hanahan D and Weinberg RA (2000). The hallmarks of cancer. Cell, 100: 57-70.

3. Hanahan D and Weinberg RA (2011). Hallmarks of cancer: the next generation. Cell, 144: 646-674.

4. Warburg O (1956). On the origin of cancer cells. Science, 123: 309-314.

5. Knudson AG, Jr. (1971). Mutation and cancer: statistical study of retinoblastoma. Proc Natl Acad Sci U S A, 68: 820-823.

6. Knudson AG (1996). Hereditary cancer: two hits revisited. J Cancer Res Clin Oncol, 122: 135-140.

7. Jones PA and Baylin SB (2002). The fundamental role of epigenetic events in cancer. Nat Rev Genet, 3: 415-428.

8. Dawson MA and Kouzarides T (2012). Cancer epigenetics: from mechanism to therapy. Cell, 150: 12-27.

9. Zhu Y and Parada LF (2002). The molecular and genetic basis of neurological tumours. Nat Rev Cancer, 2: 616-626.

10. DeLellis RA, Lloyd RV, Heitz PU, and Eng C (2004). Pathology and Genetics of Tumours of Endocrine Organs, in World Health Organization Classification of Tumours, IARC Press: Lyon, France, p. 147-166.

11. McNichol AM (2001). Differential diagnosis of pheochromocytomas and paragangliomas. Endocr Pathol, 12: 407-415.

12. Prabhakar NR and Semenza GL (2012). Gaseous messengers in oxygen sensing. $J$ Mol Med, 90: 265-272.

13. Karagiannis A, Mikhailidis DP, Athyros VG, and Harsoulis F (2007). Pheochromocytoma: an update on genetics and management. Endocr Relat Cancer, 14: 935-956.

14. Spencer E, Pycock C, and Lytle J (1993). Phaeochromocytoma presenting as acute circulatory collapse and abdominal pain. Intensive Care Med, 19: 356-357.

15. Sibal L, Jovanovic A, Agarwal SC, Peaston RT, James RA, Lennard TW, Bliss R, Batchelor A, and Perros P (2006). Phaeochromocytomas presenting as acute crises after beta blockade therapy. Clin Endocrinol, 65: 186-190.

16. Stolk RF, Bakx C, Mulder J, Timmers HJ, and Lenders JW (2013). Is the excess cardiovascular morbidity in pheochromocytoma related to blood pressure or to catecholamines? J Clin Endocrinol Metab, 98: 1100-1106.

17. Erickson D, Kudva YC, Ebersold MJ, Thompson GB, Grant CS, van Heerden JA, and Young WF, Jr. (2001). Benign paragangliomas: clinical presentation and treatment outcomes in 236 patients. J Clin Endocrinol Metab, 86: 5210-5216.

18. van Duinen N, Steenvoorden D, Kema IP, Jansen JC, Vriends AH, Bayley JP, Smit JW, Romijn JA, and Corssmit EP (2010). Increased urinary excretion of 3methoxytyramine in patients with head and neck paragangliomas. J Clin Endocrinol Metab, 95: 209-214. 
19. Chen H, Sippel RS, O'Dorisio MS, Vinik AI, Lloyd RV, and Pacak K (2010). The North American Neuroendocrine Tumor Society consensus guideline for the diagnosis and management of neuroendocrine tumors: pheochromocytoma, paraganglioma, and medullary thyroid cancer. Pancreas, 39: 775-783.

20. Lo CY, Lam KY, Wat MS, and Lam KS (2000). Adrenal pheochromocytoma remains a frequently overlooked diagnosis. Am J Surg, 179: 212-215.

21. McNeil AR, Blok BH, Koelmeyer TD, Burke MP, and Hilton JM (2000). Phaeochromocytomas discovered during coronial autopsies in Sydney, Melbourne and Auckland. Aust N Z J Med, 30: 648-652.

22. Goldstein RE, O'Neill JA, Jr., Holcomb GW, Morgan WM, Neblett WW, Oates JA, Brown N, Nadeau J, Smith B, Page DL, Abumrad NN, and Scott HW, Jr. (1999). Clinical experience over 48 years with pheochromocytoma. Ann Surg, 229: 755-764.

23. Dahia PL (2014). Pheochromocytoma and paraganglioma pathogenesis: learning from genetic heterogeneity. Nat Rev Cancer, 14: 108-119.

24. Jimenez C, Rohren E, Habra MA, Rich T, Jimenez P, Ayala-Ramirez M, and Baudin E (2013). Current and future treatments for malignant pheochromocytoma and sympathetic paraganglioma. Curr Oncol Rep, 15: 356-371.

25. Gimenez-Roqueplo AP, Favier J, Rustin P, Rieubland C, Crespin M, Nau V, Khau Van Kien P, Corvol P, Plouin PF, and Jeunemaitre X (2003). Mutations in the SDHB gene are associated with extra-adrenal and/or malignant phaeochromocytomas. Cancer Res, 63: 5615-5621.

26. Chrisoulidou A, Kaltsas G, Ilias I, and Grossman AB (2007). The diagnosis and management of malignant phaeochromocytoma and paraganglioma. Endocr Relat Cancer, 14: 569-585.

27. Favier J, Amar L, and Gimenez-Roqueplo A (2014). Paraganglioma and phaeochromocytoma: from genetics to personalized medicine. Nat Rev Endocrinol.

28. Lips C, Lentjes E, Hoppener J, Luijt R, and Moll F (2006). Familial paragangliomas. Hered Cancer Clin Pract, 4: 169-176.

29. Maher ER and Eng C (2002). The pressure rises: update on the genetics of phaeochromocytoma. Hum Mol Genet, 11: 2347-2354.

30. Baysal BE, Ferrell RE, Willett-Brozick JE, Lawrence EC, Myssiorek D, Bosch A, van der Mey A, Taschner PEM, Rubinstein WS, Myers EN, Richard CW, Cornelisse CJ, Devilee P, and Devlin B (2000). Mutations in SDHD, a mitochondrial complex II gene, in hereditary paraganglioma. Science, 287: 848-851.

31. Welander J, Soderkvist P, and Gimm O (2011). Genetics and clinical characteristics of hereditary pheochromocytomas and paragangliomas. Endocr Relat Cancer, 18: R253276.

32. Mulligan LM (2014). RET revisited: expanding the oncogenic portfolio. Nat Rev Cancer, 14: 173-186.

33. Besset V, Scott RP, and Ibanez CF (2000). Signaling complexes and protein-protein interactions involved in the activation of the Ras and phosphatidylinositol 3-kinase pathways by the c-Ret receptor tyrosine kinase. J Biol Chem, 275: 39159-39166. 
34. Califano D, Rizzo C, D'Alessio A, Colucci-D'Amato GL, Cali G, Bartoli PC, Santelli G, Vecchio G, and de Franciscis V (2000). Signaling through Ras is essential for ret oncogene-induced cell differentiation in PC12 cells. J Biol Chem, 275: 19297-19305.

35. Segouffin-Cariou C and Billaud M (2000). Transforming ability of MEN2A-RET requires activation of the phosphatidylinositol 3-kinase/AKT signaling pathway. $J$ Biol Chem, 275: 3568-3576.

36. Raue F and Frank-Raue K (2010). Update multiple endocrine neoplasia type 2. Fam Cancer, 9: 449-457.

37. Maynard MA and Ohh M (2007). The role of hypoxia-inducible factors in cancer. Cell Mol Life Sci, 64: 2170-2180.

38. Kaelin WG, Jr. (2008). The von Hippel-Lindau tumour suppressor protein: O2 sensing and cancer. Nat Rev Cancer, 8: 865-873.

39. Woodward ER and Maher ER (2006). Von Hippel-Lindau disease and endocrine tumour susceptibility. Endocr Relat Cancer, 13: 415-425.

40. Boyd KP, Korf BR, and Theos A (2009). Neurofibromatosis type 1. J Am Acad Dermatol, 61: 1-16.

41. Yap YS, McPherson JR, Ong CK, Rozen SG, Teh BT, Lee AS, and Callen DF (2014). The NF1 gene revisited - from bench to bedside. Oncotarget, 5: 5873-5892.

42. Ballester R, Marchuk D, Boguski M, Saulino A, Letcher R, Wigler M, and Collins F (1990). The NF1 locus encodes a protein functionally related to mammalian GAP and yeast IRA proteins. Cell, 63: 851-859.

43. Martin GA, Viskochil D, Bollag G, McCabe PC, Crosier WJ, Haubruck H, Conroy L, Clark R, O'Connell P, Cawthon RM, Innis MA and McCormick F (1990). The GAPrelated domain of the neurofibromatosis type 1 gene product interacts with ras p21. Cell, 63: 843-849.

44. Johannessen CM, Reczek EE, James MF, Brems H, Legius E, and Cichowski K (2005). The NF1 tumor suppressor critically regulates TSC2 and mTOR. Proc Natl Acad Sci U S A, 102: 8573-8578.

45. Johannessen CM, Johnson BW, Williams SM, Chan AW, Reczek EE, Lynch RC, Rioth MJ, McClatchey A, Ryeom S, and Cichowski K (2008). TORC1 is essential for NF1-associated malignancies. Curr Biol, 18: 56-62.

46. Walther MM, Herring J, Enquist E, Keiser HR, and Linehan WM (1999). von Recklinghausen's disease and pheochromocytomas. J Urol, 162: 1582-1586.

47. Rutter J, Winge DR, and Schiffman JD (2010). Succinate dehydrogenase - Assembly, regulation and role in human disease. Mitochondrion, 10: 393-401.

48. Niemann S and Muller U (2000). Mutations in SDHC cause autosomal dominant paraganglioma, type 3. Nat Genet, 26: 268-270.

49. Astuti D, Latif F, Dallol A, Dahia PL, Douglas F, George E, Skoldberg F, Husebye ES, Eng C, and Maher ER (2001). Gene mutations in the succinate dehydrogenase subunit SDHB cause susceptibility to familial pheochromocytoma and to familial paraganglioma. Am J Hum Genet, 69: 49-54.

50. Hao HX, Khalimonchuk O, Schraders M, Dephoure N, Bayley JP, Kunst H, Devilee P, Cremers CW, Schiffman JD, Bentz BG, Gygi SP, Winge DR, Kremer H, and Rutter 
J (2009). SDH5, a gene required for flavination of succinate dehydrogenase, is mutated in paraganglioma. Science, 325: 1139-1142.

51. van der Mey AG, Maaswinkel-Mooy PD, Cornelisse CJ, Schmidt PH, and van de Kamp JJ (1989). Genomic imprinting in hereditary glomus tumours: evidence for new genetic theory. Lancet, 2: 1291-1294.

52. Kunst HP, Rutten MH, de Monnink JP, Hoefsloot LH, Timmers HJ, Marres HA, Jansen JC, Kremer H, Bayley JP, and Cremers CW (2011). SDHAF2 (PGL2-SDH5) and hereditary head and neck paraganglioma. Clin Cancer Res, 17: 247-254.

53. Burnichon N, Briere JJ, Libe R, Vescovo L, Riviere J, Tissier F, Jouanno E, Jeunemaitre X, Benit P, Tzagoloff A, Rustin P, Bertherat J, Favier J, and GimenezRoqueplo AP (2010). SDHA is a tumor suppressor gene causing paraganglioma. Hum Mol Genet, 19: 3011-3020.

54. Gimenez-Roqueplo AP, Favier J, Rustin P, Mourad JJ, Plouin PF, Corvol P, Rotig A, and Jeunemaitre X (2001). The R22X mutation of the SDHD gene in hereditary paraganglioma abolishes the enzymatic activity of complex II in the mitochondrial respiratory chain and activates the hypoxia pathway. Am J Hum Genet, 69: 1186-1197.

55. Douwes Dekker PB, Hogendoorn PC, Kuipers-Dijkshoorn N, Prins FA, van Duinen SG, Taschner PE, van der Mey AG, and Cornelisse CJ (2003). SDHD mutations in head and neck paragangliomas result in destabilization of complex II in the mitochondrial respiratory chain with loss of enzymatic activity and abnormal mitochondrial morphology. J Pathol, 201: 480-486.

56. van Nederveen FH, Gaal J, Favier J, Korpershoek E, Oldenburg RA, de Bruyn EM, Sleddens HF, Derkx P, Riviere J, Dannenberg H, Petri BJ, Komminoth P, Pacak K, Hop WC, Pollard PJ, Mannelli M, Bayley JP, Perren A, Niemann S, Verhofstad AA, de Bruine AP, Maher ER, Tissier F, Meatchi T, Badoual C, et al. (2009). An immunohistochemical procedure to detect patients with paraganglioma and phaeochromocytoma with germline SDHB, SDHC, or SDHD gene mutations: a retrospective and prospective analysis. Lancet Oncol, 10: 764-771.

57. Gill AJ, Benn DE, Chou A, Clarkson A, Muljono A, Meyer-Rochow GY, Richardson AL, Sidhu SB, Robinson BG, and Clifton-Bligh RJ (2010). Immunohistochemistry for SDHB triages genetic testing of SDHB, SDHC, and SDHD in paragangliomapheochromocytoma syndromes. Hum Pathol, 41: 805-814.

58. Korpershoek E, Favier J, Gaal J, Burnichon N, van Gessel B, Oudijk L, Badoual C, Gadessaud N, Venisse A, Bayley JP, van Dooren MF, de Herder WW, Tissier F, Plouin PF, van Nederveen FH, Dinjens WN, Gimenez-Roqueplo AP, and de Krijger RR (2011). SDHA immunohistochemistry detects germline SDHA gene mutations in apparently sporadic paragangliomas and pheochromocytomas. J Clin Endocrinol Metab, 96: E1472-1476.

59. Richter S, Peitzsch M, Rapizzi E, Lenders JW, Qin N, de Cubas AA, Schiavi F, Rao JU, Beuschlein F, Quinkler M, Timmers HJ, Opocher G, Mannelli M, Pacak K, Robledo M, and Eisenhofer G (2014). Krebs cycle metabolite profiling for identification and stratification of pheochromocytomas/paragangliomas due to succinate dehydrogenase deficiency. J Clin Endocrinol Metab, 99: 3903-3911. 
60. Neumann HP, Pawlu C, Peczkowska M, Bausch B, McWhinney SR, Muresan M, Buchta M, Franke G, Klisch J, Bley TA, Hoegerle S, Boedeker CC, Opocher G, Schipper J, Januszewicz A, and Eng C (2004). Distinct clinical features of paraganglioma syndromes associated with SDHB and SDHD gene mutations. JAMA, 292: 943-951.

61. Dwight T, Mann K, Benn DE, Robinson BG, McKelvie P, Gill AJ, Winship I, and Clifton-Bligh RJ (2013). Familial SDHA mutation associated with pituitary adenoma and pheochromocytoma/paraganglioma. J Clin Endocrinol Metab, 98: E1103-1108.

62. Papathomas TG, Gaal J, Corssmit EP, Oudijk L, Korpershoek E, Heimdal K, Bayley JP, Morreau H, van Dooren M, Papaspyrou K, Schreiner T, Hansen T, Andresen PA, Restuccia DF, van Kessel I, van Leenders GJ, Kros JM, Looijenga LH, Hofland LJ, Mann W, van Nederveen FH, Mete O, Asa SL, de Krijger RR, and Dinjens WN (2014). Non-pheochromocytoma (PCC)/paraganglioma (PGL) tumors in patients with succinate dehydrogenase-related PCC-PGL syndromes: a clinicopathological and molecular analysis. Eur J Endocrinol, 170: 1-12.

63. Stratakis CA and Carney JA (2009). The triad of paragangliomas, gastric stromal tumours and pulmonary chondromas (Carney triad), and the dyad of paragangliomas and gastric stromal sarcomas (Carney-Stratakis syndrome): molecular genetics and clinical implications. J Intern Med, 266: 43-52.

64. Pantaleo MA, Astolfi A, Indio V, Moore R, Thiessen N, Heinrich MC, Gnocchi C, Santini D, Catena F, Formica S, Martelli PL, Casadio R, Pession A, and Biasco G (2011). SDHA loss-of-function mutations in KIT-PDGFRA wild-type gastrointestinal stromal tumors identified by massively parallel sequencing. J Natl Cancer Inst, 103: 983-987.

65. Letouze E, Martinelli C, Loriot C, Burnichon N, Abermil N, Ottolenghi C, Janin M, Menara M, Nguyen AT, Benit P, Buffet A, Marcaillou C, Bertherat J, Amar L, Rustin P, De Reynies A, Gimenez-Roqueplo AP, and Favier J (2013). SDH mutations establish a hypermethylator phenotype in paraganglioma. Cancer Cell, 23: 739-752.

66. Qin Y, Yao L, King EE, Buddavarapu K, Lenci RE, Chocron ES, Lechleiter JD, Sass M, Aronin N, Schiavi F, Boaretto F, Opocher G, Toledo RA, Toledo SP, Stiles C, Aguiar RC, and Dahia PL (2010). Germline mutations in TMEM127 confer susceptibility to pheochromocytoma. Nat Genet, 42: 229-233.

67. Yao L, Schiavi F, Cascon A, Qin Y, Inglada-Perez L, King EE, Toledo RA, Ercolino T, Rapizzi E, Ricketts CJ, Mori L, Giacche M, Mendola A, Taschin E, Boaretto F, Loli P, Iacobone M, Rossi GP, Biondi B, Lima-Junior JV, Kater CE, Bex M, Vikkula M, Grossman AB, Gruber SB, et al. (2010). Spectrum and prevalence of FP/TMEM127 gene mutations in pheochromocytomas and paragangliomas. JAMA, 304: 2611-2619.

68. Abermil N, Guillaud-Bataille M, Burnichon N, Venisse A, Manivet P, Guignat L, Drui D, Chupin M, Josseaume C, Affres H, Plouin PF, Bertherat J, Jeunemaitre X, and Gimenez-Roqueplo AP (2012). TMEM127 screening in a large cohort of patients with pheochromocytoma and/or paraganglioma. J Clin Endocrinol Metab, 97: E805-809.

69. Neumann HP, Sullivan M, Winter A, Malinoc A, Hoffmann MM, Boedeker CC, Bertz H, Walz MK, Moeller LC, Schmid KW, and Eng C (2011). Germline mutations of the 
TMEM127 gene in patients with paraganglioma of head and neck and extraadrenal abdominal sites. J Clin Endocrinol Metab, 96: E1279-1282.

70. Toledo SP, Lourenco DM, Jr., Sekiya T, Lucon AM, Baena ME, Castro CC, Bortolotto LA, Zerbini MC, Siqueira SA, Toledo RA, and Dahia PL (2015). Penetrance and Clinical Features of Pheochromocytoma in a Six-Generation Family Carrying a Germline TMEM127 Mutation. J Clin Endocrinol Metab, 100: E308-318.

71. Qin Y, Deng Y, Ricketts CJ, Srikantan S, Wang E, Maher ER, and Dahia PL (2014). The tumor susceptibility gene TMEM127 is mutated in renal cell carcinomas and modulates endolysosomal function. Hum Mol Genet, 23: 2428-2439.

72. Grandori C, Cowley SM, James LP, and Eisenman RN (2000). The Myc/Max/Mad network and the transcriptional control of cell behavior. Annu Rev Cell Dev Biol, 16: 653-699.

73. Greene LA and Tischler AS (1976). Establishment of a noradrenergic clonal line of rat adrenal pheochromocytoma cells which respond to nerve growth factor. Proc Natl Acad Sci U S A, 73: 2424-2428.

74. Hopewell R and Ziff EB (1995). The nerve growth factor-responsive PC12 cell line does not express the Myc dimerization partner Max. Mol Cell Biol, 15: 3470-3478.

75. Comino-Mendez I, Gracia-Aznarez FJ, Schiavi F, Landa I, Leandro-Garcia LJ, Leton R, Honrado E, Ramos-Medina R, Caronia D, Pita G, Gomez-Grana A, de Cubas AA, Inglada-Perez L, Maliszewska A, Taschin E, Bobisse S, Pica G, Loli P, HernandezLavado R, Diaz JA, Gomez-Morales M, Gonzalez-Neira A, Roncador G, RodriguezAntona C, Benitez J, et al. (2011). Exome sequencing identifies MAX mutations as a cause of hereditary pheochromocytoma. Nat Genet, 43: 663-667.

76. Burnichon N, Cascon A, Schiavi F, Morales NP, Comino-Mendez I, Abermil N, Inglada-Perez L, de Cubas AA, Amar L, Barontini M, de Quiros SB, Bertherat J, Bignon YJ, Blok MJ, Bobisse S, Borrego S, Castellano M, Chanson P, Chiara MD, Corssmit EP, Giacche M, de Krijger RR, Ercolino T, Girerd X, Gomez-Garcia EB, et al. (2012). MAX Mutations Cause Hereditary and Sporadic Pheochromocytoma and Paraganglioma. Clin Cancer Res, 18: 2828-2837.

77. Kaelin WG, Jr. and Ratcliffe PJ (2008). Oxygen sensing by metazoans: the central role of the HIF hydroxylase pathway. Mol Cell, 30: 393-402.

78. Keith B, Johnson RS, and Simon MC (2012). HIF1alpha and HIF2alpha: sibling rivalry in hypoxic tumour growth and progression. Nat Rev Cancer, 12: 9-22.

79. Bento C, Percy MJ, Gardie B, Maia TM, van Wijk R, Perrotta S, Della Ragione F, Almeida H, Rossi C, Girodon F, Astrom M, Neumann D, Schnittger S, Landin B, Minkov M, Randi ML, Richard S, Casadevall N, Vainchenker W, Rives S, Hermouet S, Ribeiro ML, McMullin MF, Cario H, Chauveau A, et al. (2014). Genetic basis of congenital erythrocytosis: mutation update and online databases. Hum Mutat, 35: 1526.

80. Zhuang Z, Yang C, Lorenzo F, Merino M, Fojo T, Kebebew E, Popovic V, Stratakis CA, Prchal JT, and Pacak K (2012). Somatic HIF2A gain-of-function mutations in paraganglioma with polycythemia. $N$ Engl J Med, 367: 922-930.

81. Maher ER (2013). HIF2 and endocrine neoplasia: an evolving story. Endocr Relat Cancer, 20: C5-7. 
82. Buffet A, Smati S, Mansuy L, Menara M, Lebras M, Heymann MF, Simian C, Favier J, Murat A, Cariou B, and Gimenez-Roqueplo AP (2014). Mosaicism in HIF2Arelated polycythemia-paraganglioma syndrome. J Clin Endocrinol Metab, 99: E369373.

83. Lorenzo FR, Yang C, Ng Tang Fui M, Vankayalapati H, Zhuang Z, Huynh T, Grossmann M, Pacak K, and Prchal JT (2013). A novel EPAS1/HIF2A germline mutation in a congenital polycythemia with paraganglioma. $J$ Mol Med, 91: 507-512.

84. Toledo RA, Qin Y, Srikantan S, Morales NP, Li Q, Deng Y, Kim SW, Pereira MA, Toledo SP, Su X, Aguiar RC, and Dahia PL (2013). In vivo and in vitro oncogenic effects of HIF2A mutations in pheochromocytomas and paragangliomas. Endocr Relat Cancer, 20: 349-359.

85. Pacak K, Jochmanova I, Prodanov T, Yang C, Merino MJ, Fojo T, Prchal JT, Tischler AS, Lechan RM, and Zhuang Z (2013). New syndrome of paraganglioma and somatostatinoma associated with polycythemia. J Clin Oncol, 31: 1690-1698.

86. Tomlinson IP, Alam NA, Rowan AJ, Barclay E, Jaeger EE, Kelsell D, Leigh I, Gorman P, Lamlum H, Rahman S, Roylance RR, Olpin S, Bevan S, Barker K, Hearle N, Houlston RS, Kiuru M, Lehtonen R, Karhu A, Vilkki S, Laiho P, Eklund C, Vierimaa O, Aittomaki K, Hietala M, et al. (2002). Germline mutations in FH predispose to dominantly inherited uterine fibroids, skin leiomyomata and papillary renal cell cancer. Nat Genet, 30: 406-410.

87. Castro-Vega LJ, Buffet A, De Cubas AA, Cascon A, Menara M, Khalifa E, Amar L, Azriel S, Bourdeau I, Chabre O, Curras-Freixes M, Franco-Vidal V, Guillaud-Bataille M, Simian C, Morin A, Leton R, Gomez-Grana A, Pollard PJ, Rustin P, Robledo M, Favier J, and Gimenez-Roqueplo AP (2014). Germline mutations in FH confer predisposition to malignant pheochromocytomas and paragangliomas. Hum Mol Genet, 23: 2440-2446.

88. Berra E, Benizri E, Ginouves A, Volmat V, Roux D, and Pouyssegur J (2003). HIF prolyl-hydroxylase 2 is the key oxygen sensor setting low steady-state levels of HIF1alpha in normoxia. EMBO J, 22: 4082-4090.

89. Percy MJ, Zhao Q, Flores A, Harrison C, Lappin TR, Maxwell PH, McMullin MF, and Lee FS (2006). A family with erythrocytosis establishes a role for prolyl hydroxylase domain protein 2 in oxygen homeostasis. Proc Natl Acad Sci U S A, 103: 654-659.

90. Ladroue C, Carcenac R, Leporrier M, Gad S, Le Hello C, Galateau-Salle F, Feunteun J, Pouyssegur J, Richard S, and Gardie B (2008). PHD2 mutation and congenital erythrocytosis with paraganglioma. $N$ Engl J Med, 359: 2685-2692.

91. Astuti D, Ricketts CJ, Chowdhury R, McDonough MA, Gentle D, Kirby G, Schlisio S, Kenchappa RS, Carter BD, Kaelin WG, Jr., Ratcliffe PJ, Schofield CJ, Latif F, and Maher ER (2011). Mutation analysis of HIF prolyl hydroxylases (PHD/EGLN) in individuals with features of phaeochromocytoma and renal cell carcinoma susceptibility. Endocr Relat Cancer, 18: 73-83.

92. Yang C, Zhuang Z, Fliedner SM, Shankavaram U, Sun MG, Bullova P, Zhu R, Elkahloun AG, Kourlas PJ, Merino M, Kebebew E, and Pacak K (2015). Germ-line 
PHD1 and PHD2 mutations detected in patients with pheochromocytoma/ paraganglioma-polycythemia. J Mol Med, 93: 93-104.

93. Schlisio S, Kenchappa RS, Vredeveld LC, George RE, Stewart R, Greulich H, Shahriari K, Nguyen NV, Pigny P, Dahia PL, Pomeroy SL, Maris JM, Look AT, Meyerson M, Peeper DS, Carter BD, and Kaelin WG, Jr. (2008). The kinesin KIF1Bbeta acts downstream from EglN3 to induce apoptosis and is a potential 1p36 tumor suppressor. Genes Dev, 22: 884-893.

94. Yeh IT, Lenci RE, Qin Y, Buddavarapu K, Ligon AH, Leteurtre E, Do Cao C, CardotBauters C, Pigny P, and Dahia PL (2008). A germline mutation of the KIF1B beta gene on 1 p36 in a family with neural and nonneural tumors. Hum Genet, 124: 279285.

95. Nangaku M, Sato-Yoshitake R, Okada Y, Noda Y, Takemura R, Yamazaki H, and Hirokawa N (1994). KIF1B, a novel microtubule plus end-directed monomeric motor protein for transport of mitochondria. Cell, 79: 1209-1220.

96. Zhao C, Takita J, Tanaka Y, Setou M, Nakagawa T, Takeda S, Yang HW, Terada S, Nakata T, Takei Y, Saito M, Tsuji S, Hayashi Y, and Hirokawa N (2001). CharcotMarie-Tooth disease type 2A caused by mutation in a microtubule motor KIF1Bbeta. Cell, 105: 587-597.

97. Munirajan AK, Ando K, Mukai A, Takahashi M, Suenaga Y, Ohira M, Koda T, Hirota T, Ozaki T, and Nakagawara A (2008). KIF1Bbeta functions as a haploinsufficient tumor suppressor gene mapped to chromosome 1 p36.2 by inducing apoptotic cell death. J Biol Chem, 283: 24426-24434.

98. Lee S, Nakamura E, Yang H, Wei W, Linggi MS, Sajan MP, Farese RV, Freeman RS, Carter BD, Kaelin WG, Jr., and Schlisio S (2005). Neuronal apoptosis linked to EglN3 prolyl hydroxylase and familial pheochromocytoma genes: developmental culling and cancer. Cancer Cell, 8: 155-167.

99. Schlisio S (2009). Neuronal apoptosis by prolyl hydroxylation: implication in nervous system tumours and the Warburg conundrum. J Cell Mol Med, 13: 4104-4112.

100. Wadt K, Choi J, Chung JY, Kiilgaard J, Heegaard S, Drzewiecki KT, Trent JM, Hewitt SM, Hayward NK, Gerdes AM, and Brown KM (2012). A cryptic BAP1 splice mutation in a family with uveal and cutaneous melanoma, and paraganglioma. Pigment Cell Melanoma Res, 25: 815-818.

101. Jensen DE, Proctor M, Marquis ST, Gardner HP, Ha SI, Chodosh LA, Ishov AM, Tommerup N, Vissing H, Sekido Y, Minna J, Borodovsky A, Schultz DC, Wilkinson KD, Maul GG, Barlev N, Berger SL, Prendergast GC, and Rauscher FJ, 3rd (1998). BAP1: a novel ubiquitin hydrolase which binds to the BRCA1 RING finger and enhances BRCA1-mediated cell growth suppression. Oncogene, 16: 1097-1112.

102. Harbour JW, Onken MD, Roberson ED, Duan S, Cao L, Worley LA, Council ML, Matatall KA, Helms C, and Bowcock AM (2010). Frequent mutation of BAP1 in metastasizing uveal melanomas. Science, 330: 1410-1413.

103. Wiesner T, Obenauf AC, Murali R, Fried I, Griewank KG, Ulz P, Windpassinger C, Wackernagel W, Loy S, Wolf I, Viale A, Lash AE, Pirun M, Socci ND, Rutten A, Palmedo G, Abramson D, Offit K, Ott A, Becker JC, Cerroni L, Kutzner H, Bastian 
BC, and Speicher MR (2011). Germline mutations in BAP1 predispose to melanocytic tumors. Nat Genet, 43: 1018-1021.

104. Testa JR, Cheung M, Pei J, Below JE, Tan Y, Sementino E, Cox NJ, Dogan AU, Pass HI, Trusa S, Hesdorffer M, Nasu M, Powers A, Rivera Z, Comertpay S, Tanji M, Gaudino G, Yang H, and Carbone M (2011). Germline BAP1 mutations predispose to malignant mesothelioma. Nat Genet, 43: 1022-1025.

105. Schussheim DH, Skarulis MC, Agarwal SK, Simonds WF, Burns AL, Spiegel AM, and Marx SJ (2001). Multiple endocrine neoplasia type 1: new clinical and basic findings. Trends Endocrinol Metab, 12: 173-178.

106. Neumann HP, Bausch B, McWhinney SR, Bender BU, Gimm O, Franke G, Schipper J, Klisch J, Altehoefer C, Zerres K, Januszewicz A, Eng C, Smith WM, Munk R, Manz T, Glaesker S, Apel TW, Treier M, Reineke M, Walz MK, Hoang-Vu C, Brauckhoff M, Klein-Franke A, Klose P, Schmidt H, et al. (2002). Germ-line mutations in nonsyndromic pheochromocytoma. N Engl J Med, 346: 1459-1466.

107. Amar L, Bertherat J, Baudin E, Ajzenberg C, Bressac-de Paillerets B, Chabre O, Chamontin B, Delemer B, Giraud S, Murat A, Niccoli-Sire P, Richard S, Rohmer V, Sadoul JL, Strompf L, Schlumberger M, Bertagna X, Plouin PF, Jeunemaitre X, and Gimenez-Roqueplo AP (2005). Genetic testing in pheochromocytoma or functional paraganglioma. J Clin Oncol, 23: 8812-8818.

108. Cascon A, Pita G, Burnichon N, Landa I, Lopez-Jimenez E, Montero-Conde C, Leskela S, Leandro-Garcia LJ, Leton R, Rodriguez-Antona C, Diaz JA, LopezVidriero E, Gonzalez-Neira A, Velasco A, Matias-Guiu X, Gimenez-Roqueplo AP, and Robledo M (2009). Genetics of pheochromocytoma and paraganglioma in Spanish patients. J Clin Endocrinol Metab, 94: 1701-1705.

109. Mannelli M, Castellano M, Schiavi F, Filetti S, Giacche M, Mori L, Pignataro V, Bernini G, Giache V, Bacca A, Biondi B, Corona G, Di Trapani G, Grossrubatscher E, Reimondo G, Arnaldi G, Giacchetti G, Veglio F, Loli P, Colao A, Ambrosio MR, Terzolo M, Letizia C, Ercolino T, and Opocher G (2009). Clinically guided genetic screening in a large cohort of italian patients with pheochromocytomas and/or functional or nonfunctional paragangliomas. J Clin Endocrinol Metab, 94: 1541-1547.

110. Buffet A, Venisse A, Nau V, Roncellin I, Boccio V, Le Pottier N, Boussion M, Travers C, Simian C, Burnichon N, Abermil N, Favier J, Jeunemaitre X, and Gimenez-Roqueplo AP (2012). A decade (2001-2010) of genetic testing for pheochromocytoma and paraganglioma. Horm Metab Res, 44: 359-366.

111. Muth A, Abel F, Jansson S, Nilsson O, Ahlman H, and Wangberg B (2012). Prevalence of germline mutations in patients with pheochromocytoma or abdominal paraganglioma and sporadic presentation: a population-based study in Western Sweden. World J Surg, 36: 1389-1394.

112. August C, August K, Schroeder S, Bahn H, Hinze R, Baba HA, Kersting C, and Buerger H (2004). CGH and CD 44/MIB-1 immunohistochemistry are helpful to distinguish metastasized from nonmetastasized sporadic pheochromocytomas. Mod Pathol, 17: 1119-1128.

113. van Nederveen FH, Korpershoek E, deLeeuw RJ, Verhofstad AA, Lenders JW, Dinjens WN, Lam WL, and de Krijger RR (2009). Array-comparative genomic 
hybridization in sporadic benign pheochromocytomas. Endocr Relat Cancer, 16: 505513.

114. Sandgren J, Diaz de Stahl T, Andersson R, Menzel U, Piotrowski A, Nord H, Backdahl M, Kiss NB, Brauckhoff M, Komorowski J, Dralle H, Hessman O, Larsson C, Akerstrom G, Bruder C, Dumanski JP, and Westin G (2010). Recurrent genomic alterations in benign and malignant pheochromocytomas and paragangliomas revealed by whole-genome array comparative genomic hybridization analysis. Endocr Relat Cancer, 17: 561-579.

115. Korpershoek E, Petri BJ, van Nederveen FH, Dinjens WN, Verhofstad AA, de Herder WW, Schmid S, Perren A, Komminoth P, and de Krijger RR (2007). Candidate gene mutation analysis in bilateral adrenal pheochromocytoma and sympathetic paraganglioma. Endocr Relat Cancer, 14: 453-462.

116. van Nederveen FH, Korpershoek E, Lenders JW, de Krijger RR, and Dinjens WN (2007). Somatic SDHB mutation in an extraadrenal pheochromocytoma. $N$ Engl $J$ Med, 357: 306-308.

117. Waldmann J, Langer P, Habbe N, Fendrich V, Ramaswamy A, Rothmund M, Bartsch DK, and Slater EP (2009). Mutations and polymorphisms in the SDHB, SDHD, VHL, and RET genes in sporadic and familial pheochromocytomas. Endocrine, 35: 347-355.

118. Burnichon N, Vescovo L, Amar L, Libe R, de Reynies A, Venisse A, Jouanno E, Laurendeau I, Parfait B, Bertherat J, Plouin PF, Jeunemaitre X, Favier J, and Gimenez-Roqueplo AP (2011). Integrative genomic analysis reveals somatic mutations in pheochromocytoma and paraganglioma. Hum Mol Genet, 20: 3974-3985.

119. Favier J, Buffet A, and Gimenez-Roqueplo AP (2012). HIF2A mutations in paraganglioma with polycythemia. N Engl J Med, 367: 2161-2162.

120. Comino-Mendez I, de Cubas AA, Bernal C, Alvarez-Escola C, Sanchez-Malo C, Ramirez-Tortosa CL, Pedrinaci S, Rapizzi E, Ercolino T, Bernini G, Bacca A, Leton R, Pita G, Alonso MR, Leandro-Garcia LJ, Gomez-Grana A, Inglada-Perez L, Mancikova V, Rodriguez-Antona C, Mannelli M, Robledo M, and Cascon A (2013). Tumoral EPAS1 (HIF2A) mutations explain sporadic pheochromocytoma and paraganglioma in the absence of erythrocytosis. Hum Mol Genet, 22: 2169-2176.

121. Crona J, Delgado Verdugo A, Maharjan R, Stalberg P, Granberg D, Hellman P, and Bjorklund P (2013). Somatic Mutations in H-RAS in Sporadic Pheochromocytoma and Paraganglioma Identified by Exome Sequencing. J Clin Endocrinol Metab, 98: E1266-1271.

122. Pylayeva-Gupta Y, Grabocka E, and Bar-Sagi D (2011). RAS oncogenes: weaving a tumorigenic web. Nat Rev Cancer, 11: 761-774.

123. Oudijk L, de Krijger RR, Rapa I, Beuschlein F, de Cubas AA, Dei Tos AP, Dinjens WN, Korpershoek E, Mancikova V, Mannelli M, Papotti M, Vatrano S, Robledo M, and Volante M (2014). H-RAS mutations are restricted to sporadic pheochromocytomas lacking specific clinical or pathological features: data from a multiinstitutional series. J Clin Endocrinol Metab, 99: E1376-1380.

124. Hrascan R, Pecina-Slaus N, Martic TN, Colic JF, Gall-Troselj K, Pavelic K, and Karapandza N (2008). Analysis of selected genes in neuroendocrine tumours: insulinomas and phaeochromocytomas. J Neuroendocrinol, 20: 1015-1022. 
125. Gaal J, Burnichon N, Korpershoek E, Roncelin I, Bertherat J, Plouin PF, de Krijger RR, Gimenez-Roqueplo AP, and Dinjens WN (2010). Isocitrate dehydrogenase mutations are rare in pheochromocytomas and paragangliomas. J Clin Endocrinol Metab, 95: 1274-1278.

126. Parsons DW, Jones S, Zhang X, Lin JC, Leary RJ, Angenendt P, Mankoo P, Carter H, Siu IM, Gallia GL, Olivi A, McLendon R, Rasheed BA, Keir S, Nikolskaya T, Nikolsky Y, Busam DA, Tekleab H, Diaz LA, Jr., Hartigan J, Smith DR, Strausberg RL, Marie SK, Shinjo SM, Yan H, et al. (2008). An integrated genomic analysis of human glioblastoma multiforme. Science, 321: 1807-1812.

127. Yan H, Parsons DW, Jin G, McLendon R, Rasheed BA, Yuan W, Kos I, BatinicHaberle I, Jones S, Riggins GJ, Friedman H, Friedman A, Reardon D, Herndon J, Kinzler KW, Velculescu VE, Vogelstein B, and Bigner DD (2009). IDH1 and IDH2 mutations in gliomas. $N$ Engl J Med, 360: 765-773.

128. Kang MR, Kim MS, Oh JE, Kim YR, Song SY, Seo SI, Lee JY, Yoo NJ, and Lee SH (2009). Mutational analysis of IDH1 codon 132 in glioblastomas and other common cancers. Int J Cancer, 125: 353-355.

129. Liu T, Brown TC, Juhlin CC, Andreasson A, Wang N, Backdahl M, Healy JM, Prasad ML, Korah R, Carling T, Xu D, and Larsson C (2014). The activating TERT promoter mutation C228T is recurrent in subsets of adrenal tumors. Endocr Relat Cancer, 21: 427-434.

130. Heidenreich B, Rachakonda PS, Hemminki K, and Kumar R (2014). TERT promoter mutations in cancer development. Curr Opin Genet Dev, 24: 30-37.

131. Huang FW, Hodis E, Xu MJ, Kryukov GV, Chin L, and Garraway LA (2013). Highly recurrent TERT promoter mutations in human melanoma. Science, 339: 957-959.

132. Horn S, Figl A, Rachakonda PS, Fischer C, Sucker A, Gast A, Kadel S, Moll I, Nagore E, Hemminki K, Schadendorf D, and Kumar R (2013). TERT promoter mutations in familial and sporadic melanoma. Science, 339: 959-961.

133. Dahia PL (2013). The genetic landscape of pheochromocytomas and paragangliomas: somatic mutations take center stage. J Clin Endocrinol Metab, 98: 2679-2681.

134. Welander J, Andreasson A, Brauckhoff M, Backdahl M, Larsson C, Gimm O, and Soderkvist P (2014). Frequent EPAS1/HIF2alpha exons 9 and 12 mutations in nonfamilial pheochromocytoma. Endocr Relat Cancer, 21: 495-504.

135. Welander J, Andreasson A, Juhlin CC, Wiseman RW, Backdahl M, Hoog A, Larsson C, Gimm O, and Soderkvist P (2014). Rare germline mutations identified by targeted next-generation sequencing of susceptibility genes in pheochromocytoma and paraganglioma. J Clin Endocrinol Metab, 99: E1352-1360.

136. Eisenhofer G, Lenders JW, Timmers H, Mannelli M, Grebe SK, Hofbauer LC, Bornstein SR, Tiebel O, Adams K, Bratslavsky G, Linehan WM, and Pacak K (2011). Measurements of plasma methoxytyramine, normetanephrine, and metanephrine as discriminators of different hereditary forms of pheochromocytoma. Clin Chem, 57: 411-420.

137. Lenders JW, Duh QY, Eisenhofer G, Gimenez-Roqueplo AP, Grebe SK, Murad MH, Naruse M, Pacak K, and Young WF, Jr. (2014). Pheochromocytoma and para- 
ganglioma: an endocrine society clinical practice guideline. J Clin Endocrinol Metab, 99: 1915-1942.

138. Eisenhofer G, Huynh TT, Pacak K, Brouwers FM, Walther MM, Linehan WM, Munson PJ, Mannelli M, Goldstein DS, and Elkahloun AG (2004). Distinct gene expression profiles in norepinephrine- and epinephrine-producing hereditary and sporadic pheochromocytomas: activation of hypoxia-driven angiogenic pathways in von Hippel-Lindau syndrome. Endocr Relat Cancer, 11: 897-911.

139. Dahia PL, Ross KN, Wright ME, Hayashida CY, Santagata S, Barontini M, Kung AL, Sanso G, Powers JF, Tischler AS, Hodin R, Heitritter S, Moore F, Dluhy R, Sosa JA, Ocal IT, Benn DE, Marsh DJ, Robinson BG, Schneider K, Garber J, Arum SM, Korbonits M, Grossman A, Pigny P, et al. (2005). A HIF1alpha regulatory loop links hypoxia and mitochondrial signals in pheochromocytomas. PLoS Genet, 1: 72-80.

140. Favier J, Briere JJ, Burnichon N, Riviere J, Vescovo L, Benit P, Giscos-Douriez I, De Reynies A, Bertherat J, Badoual C, Tissier F, Amar L, Libe R, Plouin PF, Jeunemaitre $\mathrm{X}$, Rustin P, and Gimenez-Roqueplo AP (2009). The Warburg effect is genetically determined in inherited pheochromocytomas. Plos One, 4: e7094.

141. Lopez-Jimenez E, Gomez-Lopez G, Leandro-Garcia LJ, Munoz I, Schiavi F, MonteroConde C, de Cubas AA, Ramires R, Landa I, Leskela S, Maliszewska A, IngladaPerez L, de la Vega L, Rodriguez-Antona C, Leton R, Bernal C, de Campos JM, DiezTascon C, Fraga MF, Boullosa C, Pisano DG, Opocher G, Robledo M, and Cascon A (2010). Research resource: Transcriptional profiling reveals different pseudohypoxic signatures in SDHB and VHL-related pheochromocytomas. Mol Endocrinol, 24: 2382-2391.

142. Burnichon N, Lepoutre-Lussey C, Laffaire J, Gadessaud N, Molinie V, Hernigou A, Plouin PF, Jeunemaitre X, Favier J, and Gimenez-Roqueplo AP (2011). A novel TMEM127 mutation in a patient with familial bilateral pheochromocytoma. Eur J Endocrinol, 164: 141-145.

143. Hensen EF, Goeman JJ, Oosting J, Van der Mey AG, Hogendoorn PC, Cremers CW, Devilee P, and Cornelisse CJ (2009). Similar gene expression profiles of sporadic, PGL2-, and SDHD-linked paragangliomas suggest a common pathway to tumorigenesis. BMC Med Genomics, 2: 25.

144. He L and Hannon GJ (2004). MicroRNAs: small RNAs with a big role in gene regulation. Nat Rev Genet, 5: 522-531.

145. de Cubas AA, Leandro-Garcia LJ, Schiavi F, Mancikova V, Comino-Mendez I, Inglada-Perez L, Perez-Martinez M, Ibarz N, Ximenez-Embun P, Lopez-Jimenez E, Maliszewska A, Leton R, Gomez Grana A, Bernal C, Alvarez-Escola C, RodriguezAntona C, Opocher G, Munoz J, Megias D, Cascon A, and Robledo M (2013). Integrative analysis of miRNA and mRNA expression profiles in pheochromocytoma and paraganglioma identifies genotype-specific markers and potentially regulated pathways. Endocr Relat Cancer, 20: 477-493.

146. Dammann R, Schagdarsurengin U, Seidel C, Trumpler C, Hoang-Vu C, Gimm O, Dralle H, Pfeifer GP, and Brauckhoff M (2005). Frequent promoter methylation of tumor-related genes in sporadic and men2-associated pheochromocytomas. Exp Clin Endocrinol Diabetes, 113: 1-7. 
147. Geli J, Kiss N, Lanner F, Foukakis T, Natalishvili N, Larsson O, Kogner P, Hoog A, Clark GJ, Ekstrom TJ, Backdahl M, Farnebo F, and Larsson C (2007). The Ras effectors NORE1A and RASSF1A are frequently inactivated in pheochromocytoma and abdominal paraganglioma. Endocr Relat Cancer, 14: 125-134.

148. Geli J, Kiss N, Karimi M, Lee JJ, Backdahl M, Ekstrom TJ, and Larsson C (2008). Global and regional CpG methylation in pheochromocytomas and abdominal paragangliomas: association to malignant behavior. Clin Cancer Res, 14: 2551-2559.

149. Kiss NB, Muth A, Andreasson A, Juhlin CC, Geli J, Backdahl M, Hoog A, Wangberg B, Nilsson O, Ahlman H, and Larsson C (2013). Acquired hypermethylation of the P16INK4A promoter in abdominal paraganglioma: relation to adverse tumor phenotype and predisposing mutation. Endocr Relat Cancer, 20: 65-78.

150. Dang L, White DW, Gross S, Bennett BD, Bittinger MA, Driggers EM, Fantin VR, Jang HG, Jin S, Keenan MC, Marks KM, Prins RM, Ward PS, Yen KE, Liau LM, Rabinowitz JD, Cantley LC, Thompson CB, Vander Heiden MG, and Su SM (2009). Cancer-associated IDH1 mutations produce 2-hydroxyglutarate. Nature, 462: 739-744.

151. Yang H, Ye D, Guan KL, and Xiong Y (2012). IDH1 and IDH2 mutations in tumorigenesis: mechanistic insights and clinical perspectives. Clin Cancer Res, 18: 5562-5571.

152. Morin A, Letouze E, Gimenez-Roqueplo AP, and Favier J (2014). Oncometabolitesdriven tumorigenesis: From genetics to targeted therapy. Int J Cancer, 135: 22372248.

153. Tennant DA, Duran RV, Boulahbel H, and Gottlieb E (2009). Metabolic transformation in cancer. Carcinogenesis, 30: 1269-1280.

154. Wiesener MS, Jurgensen JS, Rosenberger C, Scholze CK, Horstrup JH, Warnecke C, Mandriota S, Bechmann I, Frei UA, Pugh CW, Ratcliffe PJ, Bachmann S, Maxwell PH, and Eckardt KU (2003). Widespread hypoxia-inducible expression of HIF-2alpha in distinct cell populations of different organs. FASEB J, 17: 271-273.

155. Jochmanova I, Yang C, Zhuang Z, and Pacak K (2013). Hypoxia-inducible factor signaling in pheochromocytoma: turning the rudder in the right direction. $J$ Natl Cancer Inst, 105: 1270-1283.

156. Makino Y, Cao R, Svensson K, Bertilsson G, Asman M, Tanaka H, Cao Y, Berkenstam A, and Poellinger L (2001). Inhibitory PAS domain protein is a negative regulator of hypoxia-inducible gene expression. Nature, 414: 550-554.

157. Maxwell PH, Pugh CW, and Ratcliffe PJ (2001). Activation of the HIF pathway in cancer. Curr Opin Genet Dev, 11: 293-299.

158. Semenza GL (2010). Defining the role of hypoxia-inducible factor 1 in cancer biology and therapeutics. Oncogene, 29: 625-634.

159. Favier J and Gimenez-Roqueplo AP (2010). Pheochromocytomas: the (pseudo)hypoxia hypothesis. Best Pract Res Clin Endocrinol Metab, 24: 957-968.

160. Briere JJ, Favier J, Benit P, El Ghouzzi V, Lorenzato A, Rabier D, Di Renzo MF, Gimenez-Roqueplo AP, and Rustin P (2005). Mitochondrial succinate is instrumental for HIF1alpha nuclear translocation in SDHA-mutant fibroblasts under normoxic conditions. Hum Mol Genet, 14: 3263-3269. 
161. Selak MA, Armour SM, MacKenzie ED, Boulahbel H, Watson DG, Mansfield KD, Pan Y, Simon MC, Thompson CB, and Gottlieb E (2005). Succinate links TCA cycle dysfunction to oncogenesis by inhibiting HIF-alpha prolyl hydroxylase. Cancer Cell, 7: 77-85.

162. Isaacs JS, Jung YJ, Mole DR, Lee S, Torres-Cabala C, Chung YL, Merino M, Trepel J, Zbar B, Toro J, Ratcliffe PJ, Linehan WM, and Neckers L (2005). HIF overexpression correlates with biallelic loss of fumarate hydratase in renal cancer: novel role of fumarate in regulation of HIF stability. Cancer Cell, 8: 143-153.

163. Qin N, de Cubas AA, Garcia-Martin R, Richter S, Peitzsch M, Menschikowski M, Lenders JW, Timmers HJ, Mannelli M, Opocher G, Economopoulou M, Siegert G, Chavakis T, Pacak K, Robledo M, and Eisenhofer G (2014). Opposing effects of HIF1alpha and HIF2alpha on chromaffin cell phenotypic features and tumor cell proliferation: Insights from MYC-associated factor X. Int J Cancer, 135: 2054-2064.

164. Pollard PJ, El-Bahrawy M, Poulsom R, Elia G, Killick P, Kelly G, Hunt T, Jeffery R, Seedhar P, Barwell J, Latif F, Gleeson MJ, Hodgson SV, Stamp GW, Tomlinson IP, and Maher ER (2006). Expression of HIF-1alpha, HIF-2alpha (EPAS1), and their target genes in paraganglioma and pheochromocytoma with VHL and SDH mutations. J Clin Endocrinol Metab, 91: 4593-4598.

165. Vivanco I and Sawyers CL (2002). The phosphatidylinositol 3-Kinase AKT pathway in human cancer. Nat Rev Cancer, 2: 489-501.

166. McCubrey JA, Steelman LS, Chappell WH, Abrams SL, Wong EW, Chang F, Lehmann B, Terrian DM, Milella M, Tafuri A, Stivala F, Libra M, Basecke J, Evangelisti C, Martelli AM, and Franklin RA (2007). Roles of the Raf/MEK/ERK pathway in cell growth, malignant transformation and drug resistance. Biochim Biophys Acta, 1773: 1263-1284.

167. Sears R, Nuckolls F, Haura E, Taya Y, Tamai K, and Nevins JR (2000). Multiple Rasdependent phosphorylation pathways regulate Myc protein stability. Genes Dev, 14: 2501-2514.

168. Pourdehnad M, Truitt ML, Siddiqi IN, Ducker GS, Shokat KM, and Ruggero D (2013). Myc and mTOR converge on a common node in protein synthesis control that confers synthetic lethality in Myc-driven cancers. Proc Natl Acad Sci U S A, 110: 11988-11993.

169. Brugarolas J and Kaelin WG, Jr. (2004). Dysregulation of HIF and VEGF is a unifying feature of the familial hamartoma syndromes. Cancer Cell, 6: 7-10.

170. Berra E, Milanini J, Richard DE, Le Gall M, Vinals F, Gothie E, Roux D, Pages G, and Pouyssegur J (2000). Signaling angiogenesis via p42/p44 MAP kinase and hypoxia. Biochem Pharmacol, 60: 1171-1178.

171. Fukuda R, Hirota K, Fan F, Jung YD, Ellis LM, and Semenza GL (2002). Insulin-like growth factor 1 induces hypoxia-inducible factor 1-mediated vascular endothelial growth factor expression, which is dependent on MAP kinase and phosphatidylinositol 3-kinase signaling in colon cancer cells. J Biol Chem, 277: 38205-38211.

172. Zerilli M, Zito G, Martorana A, Pitrone M, Cabibi D, Cappello F, Giordano C, and Rodolico V (2010). BRAF(V600E) mutation influences hypoxia-inducible factor1alpha expression levels in papillary thyroid cancer. Mod Pathol, 23: 1052-1060. 
173. Gordan JD, Thompson CB, and Simon MC (2007). HIF and c-Myc: sibling rivals for control of cancer cell metabolism and proliferation. Cancer Cell, 12: 108-113.

174. Dang CV, Kim JW, Gao P, and Yustein J (2008). The interplay between MYC and HIF in cancer. Nat Rev Cancer, 8: 51-56.

175. Turner N and Grose R (2010). Fibroblast growth factor signalling: from development to cancer. Nat Rev Cancer, 10: 116-129.

176. Haugsten EM, Wiedlocha A, Olsnes S, and Wesche J (2010). Roles of fibroblast growth factor receptors in carcinogenesis. Mol Cancer Res, 8: 1439-1452.

177. Cheng L, Zhang S, Davidson DD, MacLennan GT, Koch MO, Montironi R, and Lopez-Beltran A (2009). Molecular determinants of tumor recurrence in the urinary bladder. Future Oncol, 5: 843-857.

178. Hernandez S, Lopez-Knowles E, Lloreta J, Kogevinas M, Amoros A, Tardon A, Carrato A, Serra C, Malats N, and Real FX (2006). Prospective study of FGFR3 mutations as a prognostic factor in nonmuscle invasive urothelial bladder carcinomas. J Clin Oncol, 24: 3664-3671.

179. Theillet C, Adelaide J, Louason G, Bonnet-Dorion F, Jacquemier J, Adnane J, Longy M, Katsaros D, Sismondi P, Gaudray P, and Birnbaum D (1993). FGFRI and PLAT genes and DNA amplification at 8p12 in breast and ovarian cancers. Genes Chromosomes Cancer, 7: 219-226.

180. Weiss J, Sos ML, Seidel D, Peifer M, Zander T, Heuckmann JM, Ullrich RT, Menon R, Maier S, Soltermann A, Moch H, Wagener P, Fischer F, Heynck S, Koker M, Schottle J, Leenders F, Gabler F, Dabow I, Querings S, Heukamp LC, Balke-Want H, Ansen S, Rauh D, Baessmann I, et al. (2010). Frequent and focal FGFR1 amplification associates with therapeutically tractable FGFR1 dependency in squamous cell lung cancer. Sci Transl Med, 2: 62ra93.

181. The Cancer Genome Atlas Research Network (2008). Comprehensive genomic characterization defines human glioblastoma genes and core pathways. Nature, 455: 1061-1068.

182. Jones DT, Hutter B, Jager N, Korshunov A, Kool M, Warnatz HJ, Zichner T, Lambert SR, Ryzhova M, Quang DA, Fontebasso AM, Stutz AM, Hutter S, Zuckermann M, Sturm D, Gronych J, Lasitschka B, Schmidt S, Seker-Cin H, Witt H, Sultan M, Ralser M, Northcott PA, Hovestadt V, Bender S, et al. (2013). Recurrent somatic alterations of FGFR1 and NTRK2 in pilocytic astrocytoma. Nat Genet, 45: 927-932.

183. Sanger F, Nicklen S, and Coulson AR (1977). DNA sequencing with chainterminating inhibitors. Proc Natl Acad Sci U S A, 74: 5463-5467.

184. Saiki RK, Gelfand DH, Stoffel S, Scharf SJ, Higuchi R, Horn GT, Mullis KB, and Erlich HA (1988). Primer-directed enzymatic amplification of DNA with a thermostable DNA polymerase. Science, 239: 487-491.

185. Koressaar T and Remm M (2007). Enhancements and modifications of primer design program Primer3. Bioinformatics, 23: 1289-1291.

186. Untergasser A, Cutcutache I, Koressaar T, Ye J, Faircloth BC, Remm M, and Rozen SG (2012). Primer3--new capabilities and interfaces. Nucleic Acids Res, 40: e115.

187. Aranyi T, Varadi A, Simon I, and Tusnady GE (2006). The BiSearch web server. BMC Bioinformatics, 7: 431. 
188. Metzker ML (2010). Sequencing technologies - the next generation. Nat Rev Genet, 11: 31-46.

189. Grada A and Weinbrecht K (2013). Next-generation sequencing: methodology and application. J Invest Dermatol, 133: e11.

190. Bentley DR (2006). Whole-genome re-sequencing. Curr Opin Genet Dev, 16: 545552.

191. DePristo MA, Banks E, Poplin R, Garimella KV, Maguire JR, Hartl C, Philippakis AA, del Angel G, Rivas MA, Hanna M, McKenna A, Fennell TJ, Kernytsky AM, Sivachenko AY, Cibulskis K, Gabriel SB, Altshuler D, and Daly MJ (2011). A framework for variation discovery and genotyping using next-generation DNA sequencing data. Nat Genet, 43: 491-498.

192. Cibulskis K, Lawrence MS, Carter SL, Sivachenko A, Jaffe D, Sougnez C, Gabriel S, Meyerson M, Lander ES, and Getz G (2013). Sensitive detection of somatic point mutations in impure and heterogeneous cancer samples. Nat Biotechnol, 31: 213-219.

193. Koboldt DC, Zhang Q, Larson DE, Shen D, McLellan MD, Lin L, Miller CA, Mardis ER, Ding L, and Wilson RK (2012). VarScan 2: somatic mutation and copy number alteration discovery in cancer by exome sequencing. Genome Res, 22: 568-576.

194. Schmittgen TD and Livak KJ (2008). Analyzing real-time PCR data by the comparative C(T) method. Nat Protoc, 3: 1101-1108.

195. Bustin SA, Benes V, Garson JA, Hellemans J, Huggett J, Kubista M, Mueller R, Nolan T, Pfaffl MW, Shipley GL, Vandesompele J, and Wittwer CT (2009). The MIQE guidelines: minimum information for publication of quantitative real-time PCR experiments. Clin Chem, 55: 611-622.

196. de Kok JB, Roelofs RW, Giesendorf BA, Pennings JL, Waas ET, Feuth T, Swinkels DW, and Span PN (2005). Normalization of gene expression measurements in tumor tissues: comparison of 13 endogenous control genes. Lab Invest, 85: 154-159.

197. Herman JG, Graff JR, Myohanen S, Nelkin BD, and Baylin SB (1996). Methylationspecific PCR: a novel PCR assay for methylation status of CpG islands. Proc Natl Acad Sci U S A, 93: 9821-9826.

198. Li LC and Dahiya R (2002). MethPrimer: designing primers for methylation PCRs. Bioinformatics, 18: 1427-1431.

199. Bibikova M, Barnes B, Tsan C, Ho V, Klotzle B, Le JM, Delano D, Zhang L, Schroth GP, Gunderson KL, Fan JB, and Shen R (2011). High density DNA methylation array with single CpG site resolution. Genomics, 98: 288-295.

200. Matsuzaki H, Dong S, Loi H, Di X, Liu G, Hubbell E, Law J, Berntsen T, Chadha M, Hui H, Yang G, Kennedy GC, Webster TA, Cawley S, Walsh PS, Jones KW, Fodor SP, and Mei R (2004). Genotyping over 100,000 SNPs on a pair of oligonucleotide arrays. Nat Methods, 1: 109-111.

201. Rabbee N and Speed TP (2006). A genotype calling algorithm for affymetrix SNP arrays. Bioinformatics, 22: 7-12.

202. Komura D, Shen F, Ishikawa S, Fitch KR, Chen W, Zhang J, Liu G, Ihara S, Nakamura H, Hurles ME, Lee C, Scherer SW, Jones KW, Shapero MH, Huang J, and Aburatani H (2006). Genome-wide detection of human copy number variations using high-density DNA oligonucleotide arrays. Genome Res, 16: 1575-1584. 
203. International HapMap Consortium (2005). A haplotype map of the human genome. Nature, 437: 1299-1320.

204. Lockhart DJ, Dong H, Byrne MC, Follettie MT, Gallo MV, Chee MS, Mittmann M, Wang C, Kobayashi M, Horton H, and Brown EL (1996). Expression monitoring by hybridization to high-density oligonucleotide arrays. Nat Biotechnol, 14: 1675-1680.

205. Irizarry RA, Hobbs B, Collin F, Beazer-Barclay YD, Antonellis KJ, Scherf U, and Speed TP (2003). Exploration, normalization, and summaries of high density oligonucleotide array probe level data. Biostatistics, 4: 249-264.

206. Benjamini Y and Hochberg Y (1995). Controlling the False Discovery Rate - a Practical and Powerful Approach to Multiple Testing. J Roy Stat Soc B Met, 57: 289300.

207. Eisen MB, Spellman PT, Brown PO, and Botstein D (1998). Cluster analysis and display of genome-wide expression patterns. Proc Natl Acad Sci U S A, 95: 1486314868.

208. Holton TA and Graham MW (1991). A simple and efficient method for direct cloning of PCR products using ddT-tailed vectors. Nucleic Acids Res, 19: 1156.

209. Coons AH and Kaplan MH (1950). Localization of antigen in tissue cells; improvements in a method for the detection of antigen by means of fluorescent antibody. J Exp Med, 91: 1-13.

210. Ramos-Vara JA and Miller MA (2014). When tissue antigens and antibodies get along: revisiting the technical aspects of immunohistochemistry--the red, brown, and blue technique. Vet Pathol, 51: 42-87.

211. Espina V, Wulfkuhle JD, Calvert VS, VanMeter A, Zhou W, Coukos G, Geho DH, Petricoin EF, 3rd, and Liotta LA (2006). Laser-capture microdissection. Nat Protoc, 1: 586-603.

212. Welander J, Larsson C, Backdahl M, Hareni N, Sivler T, Brauckhoff M, Soderkvist P, and Gimm O (2012). Integrative genomics reveals frequent somatic NF1 mutations in sporadic pheochromocytomas. Hum Mol Genet, 21: 5406-5416.

213. Lin M, Wei LJ, Sellers WR, Lieberfarb M, Wong WH, and Li C (2004). dChipSNP: significance curve and clustering of SNP-array-based loss-of-heterozygosity data. Bioinformatics, 20: 1233-1240.

214. Lui WO, Chen J, Glasker S, Bender BU, Madura C, Khoo SK, Kort E, Larsson C, Neumann HP, and Teh BT (2002). Selective loss of chromosome 11 in pheochromocytomas associated with the VHL syndrome. Oncogene, 21: 1117-1122.

215. Kugelberg J, Welander J, Schiavi F, Fassina A, Backdahl M, Larsson C, Opocher G, Soderkvist P, Dahia PL, Neumann HP, and Gimm O (2014). Role of SDHAF2 and SDHD in von Hippel-Lindau associated pheochromocytomas. World J Surg, 38: 724732.

216. Cascon A, Ruiz-Llorente S, Fraga MF, Leton R, Telleria D, Sastre J, Diez JJ, Martinez Diaz-Guerra G, Diaz Perez JA, Benitez J, Esteller M, and Robledo M (2004). Genetic and epigenetic profile of sporadic pheochromocytomas. J Med Genet, 41: e30.

217. Andreasson A, Kiss NB, Caramuta S, Sulaiman L, Svahn F, Backdahl M, Hoog A, Juhlin CC, and Larsson C (2013). The VHL gene is epigenetically inactivated in pheochromocytomas and abdominal paragangliomas. Epigenetics, 8: 1347-1354. 
218. Welander J, Soderkvist P, and Gimm O (2013). The NF1 gene: a frequent mutational target in sporadic pheochromocytomas and beyond. Endocr Relat Cancer, 20: C13-17.

219. Shapiro MB and Senapathy P (1987). RNA splice junctions of different classes of eukaryotes: sequence statistics and functional implications in gene expression. Nucleic Acids Res, 15: 7155-7174.

220. Burnichon N, Buffet A, Parfait B, Letouze E, Laurendeau I, Loriot C, Pasmant E, Abermil N, Valeyrie-Allanore L, Bertherat J, Amar L, Vidaud D, Favier J, and Gimenez-Roqueplo AP (2012). Somatic NF1 inactivation is a frequent event in sporadic pheochromocytoma. Hum Mol Genet, 21: 5397-5405.

221. Bottillo I, Ahlquist T, Brekke H, Danielsen SA, van den Berg E, Mertens F, Lothe RA, and Dallapiccola B (2009). Germline and somatic NF1 mutations in sporadic and NF1-associated malignant peripheral nerve sheath tumours. J Pathol, 217: 693-701.

222. Parkin B, Ouillette P, Wang Y, Liu Y, Wright W, Roulston D, Purkayastha A, Dressel A, Karp J, Bockenstedt P, Al-Zoubi A, Talpaz M, Kujawski L, Shedden K, Shakhan S, Li C, Erba H, and Malek SN (2010). NF1 inactivation in adult acute myelogenous leukemia. Clin Cancer Res, 16: 4135-4147.

223. Holzel M, Huang S, Koster J, Ora I, Lakeman A, Caron H, Nijkamp W, Xie J, Callens T, Asgharzadeh S, Seeger RC, Messiaen L, Versteeg R, and Bernards R (2010). NF1 is a tumor suppressor in neuroblastoma that determines retinoic acid response and disease outcome. Cell, 142: 218-229.

224. Ding L, Getz G, Wheeler DA, Mardis ER, McLellan MD, Cibulskis K, Sougnez C, Greulich H, Muzny DM, Morgan MB, Fulton L, Fulton RS, Zhang Q, Wendl MC, Lawrence MS, Larson DE, Chen K, Dooling DJ, Sabo A, Hawes AC, Shen H, Jhangiani SN, Lewis LR, Hall O, Zhu Y, et al. (2008). Somatic mutations affect key pathways in lung adenocarcinoma. Nature, 455: 1069-1075.

225. The Cancer Genome Atlas Research Network (2011). Integrated genomic analyses of ovarian carcinoma. Nature, 474: 609-615.

226. Chan DA, Sutphin PD, Yen SE, and Giaccia AJ (2005). Coordinate regulation of the oxygen-dependent degradation domains of hypoxia-inducible factor 1 alpha. Mol Cell Biol, 25: 6415-6426.

227. Modrek B, Ge L, Pandita A, Lin E, Mohan S, Yue P, Guerrero S, Lin WM, Pham T, Modrusan Z, Seshagiri S, Stern HM, Waring P, Garraway LA, Chant J, Stokoe D, and Cavet $G$ (2009). Oncogenic activating mutations are associated with local copy gain. Mol Cancer Res, 7: 1244-1252.

228. Yang C, Sun MG, Matro J, Huynh TT, Rahimpour S, Prchal JT, Lechan R, Lonser R, Pacak K, and Zhuang Z (2013). Novel HIF2A mutations disrupt oxygen sensing, leading to polycythemia, paragangliomas, and somatostatinomas. Blood, 121: 25632566.

229. Adzhubei IA, Schmidt S, Peshkin L, Ramensky VE, Gerasimova A, Bork P, Kondrashov AS, and Sunyaev SR (2010). A method and server for predicting damaging missense mutations. Nat Methods, 7: 248-249.

230. Huynh TT, Pacak K, Wong DL, Linehan WM, Goldstein DS, Elkahloun AG, Munson PJ, and Eisenhofer G (2006). Transcriptional regulation of phenylethanolamine N- 
methyltransferase in pheochromocytomas from patients with von Hippel-Lindau syndrome and multiple endocrine neoplasia type 2. Ann N Y Acad Sci, 1073: 241-252.

231. Percy MJ, Furlow PW, Lucas GS, Li X, Lappin TR, McMullin MF, and Lee FS (2008). A gain-of-function mutation in the HIF2A gene in familial erythrocytosis. $N$ Engl J Med, 358: 162-168.

232. Taieb D, Yang C, Delenne B, Zhuang Z, Barlier A, Sebag F, and Pacak K (2013). First report of bilateral pheochromocytoma in the clinical spectrum of HIF2A-related polycythemia-paraganglioma syndrome. J Clin Endocrinol Metab, 98: E908-913.

233. Jamilloux Y, Favier J, Pertuit M, Delage-Corre M, Lopez S, Teissier MP, Mathonnet M, Galinat S, Barlier A, and Archambeaud F (2014). A MEN1 syndrome with a paraganglioma. Eur J Hum Genet, 22: 283-285.

234. Edstrom E, Mahlamaki E, Nord B, Kjellman M, Karhu R, Hoog A, Goncharov N, Teh BT, Backdahl M, and Larsson C (2000). Comparative genomic hybridization reveals frequent losses of chromosomes $1 p$ and $3 q$ in pheochromocytomas and abdominal paragangliomas, suggesting a common genetic etiology. Am J Pathol, 156: 651-659.

235. Schwarz JM, Rodelsperger C, Schuelke M, and Seelow D (2010). MutationTaster evaluates disease-causing potential of sequence alterations. Nat Methods, 7: 575-576.

236. Sievers F, Wilm A, Dineen D, Gibson TJ, Karplus K, Li W, Lopez R, McWilliam H, Remmert M, Soding J, Thompson JD, and Higgins DG (2011). Fast, scalable generation of high-quality protein multiple sequence alignments using Clustal Omega. Mol Syst Biol, 7: 539.

237. Denes J, Swords F, Rattenberry E, Stals K, Owens M, Cranston T, Xekouki P, Moran L, Kumar A, Wassif C, Fersht N, Baldeweg SE, Morris D, Lightman S, Agha A, Rees A, Grieve J, Powell M, Boguszewski CL, Dutta P, Thakker RV, Srirangalingam U, Thompson CJ, Druce M, Higham C, et al. (2015). Heterogeneous genetic background of the association of pheochromocytoma/paraganglioma and pituitary adenoma: results from a large patient cohort. J Clin Endocrinol Metab, 100: E531-541.

238. Chen ZX, Wallis K, Fell SM, Sobrado VR, Hemmer MC, Ramskold D, Hellman U, Sandberg R, Kenchappa RS, Martinson T, Johnsen JI, Kogner P, and Schlisio S (2014). RNA helicase A is a downstream mediator of KIF1Bbeta tumor-suppressor function in neuroblastoma. Cancer Discov, 4: 434-451.

239. Welander J, Garvin S, Bohnmark R, Isaksson L, Wiseman RW, Soderkvist P, and Gimm O (2013). Germline SDHA mutation detected by next-generation sequencing in a young index patient with large paraganglioma. J Clin Endocrinol Metab, 98: E13791380 .

240. Fishbein L, Merrill S, Fraker DL, Cohen DL, and Nathanson KL (2013). Inherited mutations in pheochromocytoma and paraganglioma: why all patients should be offered genetic testing. Ann Surg Oncol, 20: 1444-1450.

241. Cheon JY, Mozersky J, and Cook-Deegan R (2014). Variants of uncertain significance in BRCA: a harbinger of ethical and policy issues to come? Genome Med, 6: 121.

242. Canu L, Rapizzi E, Zampetti B, Fucci R, Nesi G, Richter S, Qin N, Giache V, Bergamini C, Parenti G, Valeri A, Ercolino T, Eisenhofer G, and Mannelli M (2014). Pitfalls in genetic analysis of pheochromocytomas/paragangliomas-case report. J Clin Endocrinol Metab, 99: 2321-2326. 
243. Lawrence MS, Stojanov P, Polak P, Kryukov GV, Cibulskis K, Sivachenko A, Carter SL, Stewart C, Mermel CH, Roberts SA, Kiezun A, Hammerman PS, McKenna A, Drier Y, Zou L, Ramos AH, Pugh TJ, Stransky N, Helman E, Kim J, Sougnez C, Ambrogio L, Nickerson E, Shefler E, Cortes ML, et al. (2013). Mutational heterogeneity in cancer and the search for new cancer-associated genes. Nature, 499: 214-218.

244. Forbes SA, Bindal N, Bamford S, Cole C, Kok CY, Beare D, Jia M, Shepherd R, Leung K, Menzies A, Teague JW, Campbell PJ, Stratton MR, and Futreal PA (2011). COSMIC: mining complete cancer genomes in the Catalogue of Somatic Mutations in Cancer. Nucleic Acids Res, 39: D945-950.

245. Yoon K, Nery S, Rutlin ML, Radtke F, Fishell G, and Gaiano N (2004). Fibroblast growth factor receptor signaling promotes radial glial identity and interacts with Notch1 signaling in telencephalic progenitors. J Neurosci, 24: 9497-9506.

246. Lew ED, Furdui CM, Anderson KS, and Schlessinger J (2009). The precise sequence of FGF receptor autophosphorylation is kinetically driven and is disrupted by oncogenic mutations. Sci Signal, 2: ra6.

247. Hausott B, Schlick B, Vallant N, Dorn R, and Klimaschewski L (2008). Promotion of neurite outgrowth by fibroblast growth factor receptor 1 overexpression and lysosomal inhibition of receptor degradation in pheochromocytoma cells and adult sensory neurons. Neuroscience, 153: 461-473.

248. Fishbein L, Khare S, Wubbenhorst B, DeSloover D, D'Andrea K, Merrill S, Cho NW, Greenberg RA, Else T, Montone K, LiVolsi V, Fraker D, Daber R, Cohen DL, and Nathanson KL (2015). Whole-exome sequencing identifies somatic ATRX mutations in pheochromocytomas and paragangliomas. Nat Commun, 6: 6140.

249. Ratnakumar K and Bernstein E (2013). ATRX: the case of a peculiar chromatin remodeler. Epigenetics, 8: 3-9.

250. Flynn A, Benn D, Clifton-Bligh R, Robinson B, Trainer AH, James P, Hogg A, Waldeck K, George J, Li J, Fox SB, Gill AJ, McArthur G, Hicks RJ, and Tothill RW (2014). The genomic landscape of phaeochromocytoma. J Pathol (published online ahead of print).

251. Castro-Vega LJ, Letouze E, Burnichon N, Buffet A, Disderot PH, Khalifa E, Loriot C, Elarouci N, Morin A, Menara M, Lepoutre-Lussey C, Badoual C, Sibony M, Dousset B, Libe R, Zinzindohoue F, Plouin PF, Bertherat J, Amar L, de Reynies A, Favier J, and Gimenez-Roqueplo AP (2015). Multi-omics analysis defines core genomic alterations in pheochromocytomas and paragangliomas. Nat Commun, 6: 6044. 
APPENDIX (PAPERS I-IV) 



\section{Papers}

The articles associated with this thesis have been removed for copyright reasons. For more details about these see:

http://urn.kb.se/resolve?urn=urn:nbn:se:liu:diva-114806 